Key Words:

Bubbler

Vitrification

Retention:

Permanent

Key WTP R\&T References:

Test Specification TSP-W375-00-0032, Rev2

Task Plan WSRC-TR-2000-00412

\title{
HIGH-TEMPERATURE CORROSION STUDY FOR THE RPP LOW ACTIVITY WASTE MELTER (U)
}

K. J. Imrich, 773-A

K. M. Marshall, 773-A

A. R. Jurgensen, 773-A

J. W. Congdon, 773-A

April 22, 2003

Westinghouse Savannah River Company

Savannah River Site

Aiken, SC 29808

Prepared for the U.S. Department of Energy Under Contract Number DE-AC09-96SR18500

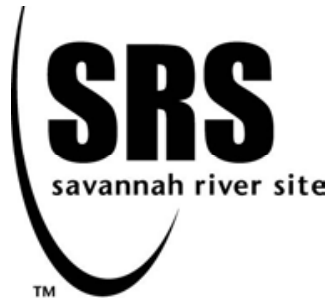


This document was prepared in conjunction with work accomplished under Contract No. DE-AC09-96SR18500 with the U. S. Department of Energy.

\section{DISCLAIMER}

This report was prepared as an account of work sponsored by an agency of the United States Government. Neither the United States Government nor any agency thereof, nor any of their employees, makes any warranty, express or implied, or assumes any legal liability or responsibility for the accuracy, completeness, or usefulness of any information, apparatus, product or process disclosed, or represents that its use would not infringe privately owned rights. Reference herein to any specific commercial product, process or service by trade name, trademark, manufacturer, or otherwise does not necessarily constitute or imply its endorsement, recommendation, or favoring by the United States Government or any agency thereof. The views and opinions of authors expressed herein do not necessarily state or reflect those of the United States Government or any agency thereof.

This report has been reproduced directly from the best available copy.

Available for sale to the public, in paper, from: U.S. Department of Commerce, National Technical Information Service, 5285 Port Royal Road, Springfield, VA 22161, phone: (800) 553-6847, fax: (703) 605-6900

email: orders@ntis.fedworld.gov

online ordering: http://www.ntis.gov/help/index.asp

Available electronically at http://www.osti.gov/bridge

Available for a processing fee to U.S. Department of Energy and its contractors, in paper, from: U.S. Department of Energy, Office of Scientific and Technical Information, P.O. Box 62, Oak Ridge, TN 37831-0062,

phone: (865)576-8401,

fax: (865)576-5728

email: $\underline{\text { reports@ adonis.osti.gov }}$ 
WSRC-TR-2002-00588, REV. 0

SRT-RPP-2002-00283. REV. 0

\section{TABLE OF CONTENTS}

LIST OF FIGURES .............................................................................................................. iv

LIST OF TABLES ................................................................................................................... vi

LIST OF ACRONYMS ................................................................................................................ vii

1.0 SUMMARY OF TESTING ................................................................................... 1

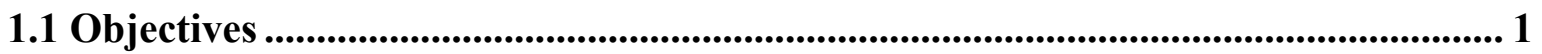

1.2 Conduct of testing ....................................................................................................................... 1

1.3 Results and Perforamce Against Objectives ........................................................................ 2

1.4 Quality Requirements ......................................................................................................... 4

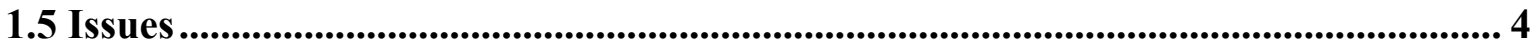

2.0 CD-ROM ENCLOSURES............................................................................................. 5

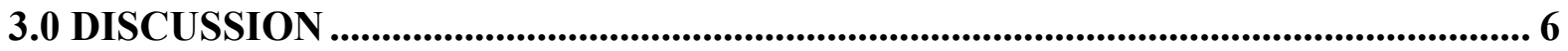

3.1 Introduction ................................................................................................................. 6

3.2 Quality Assurance ................................................................................................................... 7

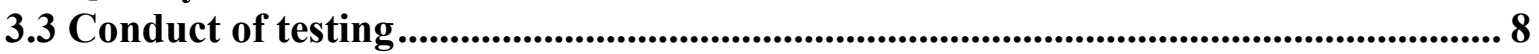

3.3.1 Materials ............................................................................................................................. 8

3.3.1.1 Glass and Feed Characterization ............................................................................... 8

3.3.1.2 Coupon preparation ..................................................................................................... 15

3.3.2 Experimental Setup and Method ............................................................................ 20

3.3.2.1 Molten Glass Experimental Setup and Method .................................................... 20

3.3.2.2 Vapor Space Experimental Setup and Method................................................... 20

3.3.3 Preparation of coupons for analysis after testing..................................................... 23

3.4 Results and Discussion ........................................................................................................ 24

3.4.1 Molten Glass Experiment ..................................................................................... 24

3.4.2 Long-Term Vapor Space Experiment............................................................................ 27

3.4.2.1 Operational Results and Observations .................................................................. 27

3.4.2.2 Chemical Analysis of Materials on Coupon Surfaces....................................... 30

3.4.2.3 Metallography ........................................................................................................... 33

3.5 Bubbler Material Selection and Fabrication ............................................................ 38

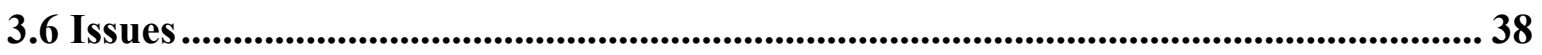

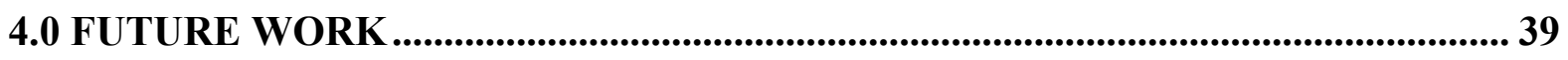

APPENDIX A. Simulant and Glass Feed Information .............................................................. 1

APPENDIX B. XRF Sample Preparation and Instrumentation .......................................... 5

APPENDIX C. SEM Micrographs for Molten Glass Experiment ................................... A-9

APPENDIX D. 20x and 100x SEM Micrographs for Long-Term Vapor Space

Experiment.............................................................................................................17

APPENDIX E. $4^{\circ}{ }^{\circ} \mathrm{C}$ SEM Micrographs for Long-Term Vapor Space

Experiment ................................................................................................................................ A-24

APPENDIX F. $6^{\circ}{ }^{\circ} \mathrm{C}$ SEM Micrographs for Long-Term Vapor Space

Experiment .................................................................................................................................. A-33

APPENDIX G. $9^{\circ}{ }^{\circ} \mathrm{C}$ SEM Micrographs for Long-Term Vapor Space

Experiment ....................................................................................................................................... A-45 


\section{LIST OF FIGURES}

Figure 3-1 Plot of Phosphate Concentration in Simulant Glass Versus Time at $1150^{\circ} \mathrm{C}$...... 10 Figure 3-2 Plot of Sulfate Concentration in Simulant Glass Versus Time at $1150^{\circ} \mathrm{C}$............ 10 Figure 3-3 Plot of Chloride Concentration in Simulant Glass Versus Time at $1150^{\circ} \mathrm{C}$......... 10 Figure 3-4 TGA Plot of Weight Loss Vs. Time for LAW Melter Feed Simulant Slurry ....... 13

Figure 3-5 Mass Spec Data Identifying Offgas Components Released from Simulant ......... 14 Figure 3-6 Molten Glass Experiment Coupons Prior to Testing ……….................................. 17 Figure 3-7 Pt-Coated I-693 Coupon for Molten Glass Testing, Prior to Testing ……............ 17 Figure 3-8 Pt-Coated Coupon Showing Flaw inside of Attachment Point.............................. 17

Figure 3-9 I-693 Coupons for Vapor Testing, Prior to Testing .............................................. 18

Figure 3-10 MA 758 Coupons for Vapor Testing, Prior to Testing …………………........... 18

Figure 3-11 Pt-Coated I-693 Coupons for Vapor Testing, Prior to Testing ............................ 18

Figure 3-12 SRTC Coupons for Vapor Testing, Prior to Testing............................................ 18

Figure 3-13 AE 7855 (A) and Amdry (G) Coupons for Vapor Testing, Prior to Testing ...... 18

Figure 3-14 Molten Glass Coupon Rack Prior to Testing, ................................................... 20

Figure 3-15 Molten Glass Coupon Rack and Crucible, Prior to Testing................................. 20

Figure 3-16 Long-Term Vapor Space Test Apparatus a) Closeup of three coupon positions

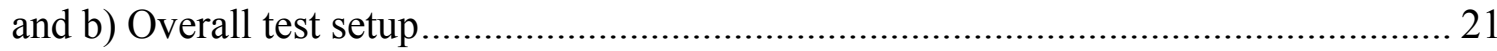

Figure 3-17 Schematic of Long-Term Vapor Space Apparatus ............................................. 22

Figure 3-18 Coupon Holder for the $600^{\circ} \mathrm{C}$ Zone, Before Testing ........................................ 23

Figure 3-19 Cross Section Cut for Coupons ...................................................................... 24

Figure 3-20 Molten Glass Testing Coupons After Completion of Experiment....................... 24

Figure 3-21 SEM Photographs Showing Condition of Coupons After Molten Glass Exposure.

Figure 3-22 Long-Term Vapor Space Coupons from $400^{\circ} \mathrm{C}$ Region, After Testing ............. 29

Figure 3-23 Long-Term Vapor Space Coupons from $600^{\circ} \mathrm{C}$ Region, After Testing ............. 29

Figure 3-24 Long-Term Vapor Space Coupons from $900^{\circ} \mathrm{C}$ Region, After Testing ............. 29

Figure 3-25 SEM Micrograph; I-693 at $400^{\circ} \mathrm{C}$ Cross Section................................................ 34

Figure 3-26 SEM Micrograph; MA 758 at $400^{\circ} \mathrm{C}$ Cross Section.......................................... 34

Figure 3-27 SEM; Pt-Coated I-693 at $400^{\circ} \mathrm{C}$ Cross Section ................................................ 34

Figure 3-28 SEM; Micrograph; SRTC at $400^{\circ} \mathrm{C}$ Cross Section ........................................... 34

Figure 3-29 SEM Micrograph; I-693 at $600^{\circ} \mathrm{C}$ Cross Section.............................................. 35

Figure 3-30 SEM Micrograph; MA 758 at $600^{\circ} \mathrm{C}$ Cross Section ....................................................... 35

Figure 3-31 SEM; Pt-Coated I-693 at $600^{\circ} \mathrm{C}$ Cross Section................................................ 35

Figure 3-32 SEM; Micrograph; SRTC at $600^{\circ} \mathrm{C}$ Cross Section ........................................... 35

Figure 3-33 Cross Section of Pt-Coated I-693 Coupon Showing Layers of Ni-Cr Oxide on

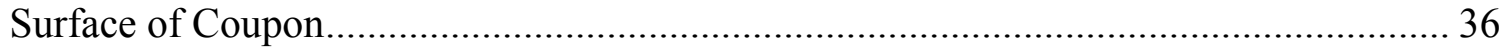

Figure 3-34 SEM Micrograph; I-693 at $900^{\circ} \mathrm{C}$ Cross Section.............................................. 37

Figure 3-35 SEM Micrograph; MA 758 at $900^{\circ} \mathrm{C}$ Cross Section.......................................... 37

Figure 3-36 SEM; Pt-Coated I-693 at $900^{\circ} \mathrm{C}$ Cross Section ................................................. 37

Figure 3-37 SEM; Micrograph; SRTC at $900^{\circ} \mathrm{C}$ Cross Section ........................................... 37

Figure A-1 Chain of Custody Form for the Glass and Melter Feed Simulant ...................... A-2 
Figure C-1 SEM Photographs and EDS analyses from the glass contact region of the Inconel 693 coupon. A-10

Figure C-2 SEM Photographs and EDS analyses from the vapor space region of the Inconel 693 coupon. A-11

Figure C-3 SEM Photographs and EDS analyses from the glass contact region of the Inconel MA 758 coupon. A-12

Figure C-4 SEM Photographs and EDS analyses from the vapor space region of the Inconel MA 758 coupon... A-13

Figure C-5 SEM Photographs and EDS analyses from the glass contact region of the SRTC alloy coupon.

Figure C-6 SEM Photographs and EDS analyses from the vapor space region of the SRTC alloy coupon. A-15

Figure C-7 SEM Photographs of the platinum-coated Inconel 693 coupon from the glass contact region after exposure (A, B and $\mathrm{C}$ ) and in the as received condition (DandE).

Figure D-1 20X SEM Photos of CouponCross Sections from $400^{\circ} \mathrm{C}$ Zone ...................... A-18

Figure D-2 20X SEM Photos of CouponCross Sections from $600^{\circ} \mathrm{C}$ Zone ...................... A-19

FigureD-3 20X SEM Photos of CouponCross Sections from $900^{\circ} \mathrm{C}$ Zone ...................... A-20

Figure D-4 100X SEM Photos of CouponCross Sections from $400^{\circ} \mathrm{C}$ Zone .................... A-21

Figure D-5 100X SEM Photos of CouponCross Sections from $600^{\circ} \mathrm{C}$ Zone .................... A-22

Figure D-6 100X SEM Photos of CouponCross Sections from $900^{\circ} \mathrm{C}$ Zone .................... A-23

Figure E-1 SEM Photos Showing Depth of Attack, I-693 at 400 C . ......................................... A-25

Figure E-2 SEM and EDS of I-693 from $400^{\circ} \mathrm{C}$ Zone .................................................... A-26

Figure E-3 SEM Photos Showing Depth of Attack, Pt-Coated I-693 at $400^{\circ} \mathrm{C}$. ................................. A-27

Figure E-4 Pt SEM and EDS of Pt-Coated I-693 from $400^{\circ} \mathrm{C}$ Zone ................................ A-28

Figure E-5 SEM Photos Showing Depth of Attack, MA 758 at $400^{\circ} \mathrm{C}$............................ A-29

Figure E-6 SEM and EDS of MA 758 from $400^{\circ} \mathrm{C}$ Zone ............................................ A-30

Figure E-7 SEM Photos Showing Depth of Attack, SRTC Alloy at $400{ }^{\circ} \mathrm{C}$.................................... A-31

Figure E-8 SEM and EDS of SRTC Alloy from $400^{\circ} \mathrm{C}$ Zone........................................ A-32

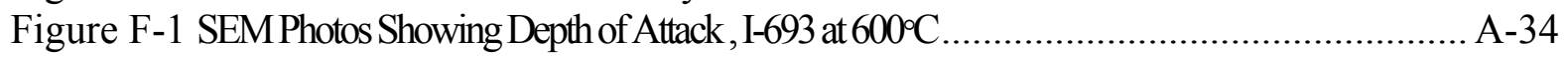

Figure F-2 SEM and EDS of I-693 from $600^{\circ} \mathrm{C}$ Zone .................................................. A-35

Figure F-3 SEM and EDS of I-693 from $600^{\circ} \mathrm{C}$ Zone, cont....................................... A-36

Figure F-4 SEM Photos Showing Depth of Attack, Pt-Coated I-693 at $600^{\circ} \mathrm{C}$.................................. A-37

Figure F-5 SEM and EDS of Pt-Coated I-693 from $600^{\circ} \mathrm{C}$ Zone ................................... A-38

Figure F-6 SEM and EDS of Pt-Coated I-693 from $600^{\circ} \mathrm{C}$ Zone, cont. ........................... A-39

Figure F-7 SEM Photos Showing Depth of Attack, MA 758 at $600^{\circ} \mathrm{C}$........................................ A-40

Figure F-8 SEM and EDS of MA 758 from $600^{\circ} \mathrm{C}$ Zone ........................................... A-41

Figure F-9 SEM Photos Showing Depth of Attack, SRTC Alloy at $600^{\circ} \mathrm{C}$...................................... A-42

Figure F-10 SEM and EDS of SRTC Alloy from $600^{\circ} \mathrm{C}$ Zone....................................... A-43

Figure F-11 SEM and EDS of SRTC Alloy from $600^{\circ} \mathrm{C}$ Zone, cont.............................. A-44

Figure G-1 SEMPhotos Showing Depth of Attack, I-693 at 900 C............................................ A-46

Figure G-2 SEM and EDS of I-693 from $900^{\circ} \mathrm{C}$ Zone ................................................ A-47

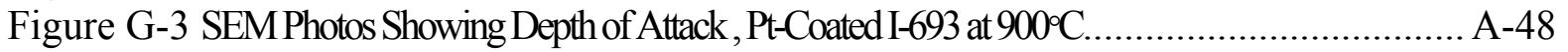

Figure G-4 SEM and EDS of Pt-Coated I-693 from $900^{\circ} \mathrm{C}$ Zone ................................... A-49

Figure G-5 SEMPhotos Showing Depth of Attack, MA 758 at $900^{\circ} \mathrm{C}$....................................... A-50

Figure G-6 SEM and EDS of MA 758 from $900^{\circ} \mathrm{C}$ Zone........................................... A-51

Figure G-7 SEM Photos Showing Depth of Attack; SRTC Alloy at $900^{\circ} \mathrm{C}$..................................... A-52 
Figure G-8 SEM and EDS of SRTC Alloy from $900^{\circ} \mathrm{C}$ Zone A-53

Figure G-9SEM and EDS of SRTC Alloy from $900^{\circ} \mathrm{C}$ Zone. A-54

\section{LIST OF TABLES}

Table 1-1 Summary of Data Used to Calculate Total Degradation from One Side of the Coupons. 3

Table 1-2 Qualitative Ranking of Long-Term Vapor Space Coupons .................................... 4

Table 3-1 LAW Sub-Envelope A1 Simulant Glass Composition ............................................ 8

Table 3-2 Results of Three-Day Glass Compositional Study .................................................. 9

Table 3-3 LAW Sub-Envelope A1 Simulant Feed Composition, 1 Liter Basis ...................... 11

Table 3-4 LAW Sub-Envelope A1 Glass Former Additives per 1 Liter of Simulant Feed.... 12

Table 3-5 LAW Sub-Envelope A1 Simulant Feed ICP Data ………………………............ 12

Table 3-6 LAW Sub-Envelope A1 Simulant Feed IC Data.................................................... 13

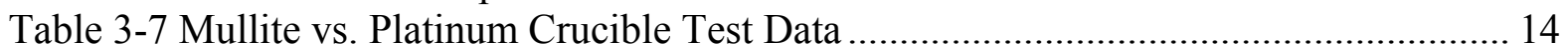

Table 3-8 Heat Chemistries for Coupon Alloys ................................................................. 15

Table 3-9 Material Certifications for Amdry 964 and AE 7855 Coatings ............................. 16

Table 3-10 Initial Coupon Dimensions (cm) for Molten Glass Experiment ........................... 19

Table 3-11 Initial Coupon Dimensions (cm) for Vapor Space Experiment ........................... 19

Table 3-12 Final Thickness and Depth of Internal Attack Following Molten Glass Exposure.

Table 3-13 Total Degradation Using Maximum and Average Depth of Attack..................... 27

Table 3-14 Operational Summary of Vapor Space Corrosion Experiment ............................. 28

Table 3-15 Coupon Weight Changes for Long-Term Vapor Space Experiment..................... 30

Table 3-16 XRF Data for Long-Term Vapor Space Coupons, After Testing ………….......... 31

Table 3-17 ICP Leach Data for Long-Term Vapor Space Coupons, After Testing ................ 32

Table 3-18 IC Leach Data for Long-Term Vapor Space Coupons, After Testing .................. 32

Table 3-19 Qualitative Ranking of Long-Term Vapor Space Coupons ................................. 33

Table 3-20 Internal Depth of Attack for Long-Term Vapor Space Coupons .......................... 33

Table 3-21 UT Measurements of Bubbler Sub-assembly....................................................... 38

Table A-1 RPP LLW Envelope A Simulant Melter Feed with Additives, used in Long-Term

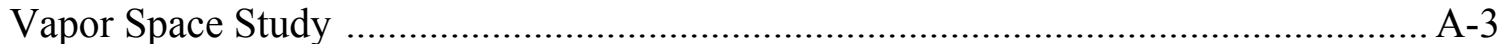

Table A-2 Complete Data for Mullite vs. Platinum Crucible Test ..................................... A-4

Table B-1 Rigaku 3271 Wavelength-dispersive X-ray Fluorescence Spectrometer Parameters

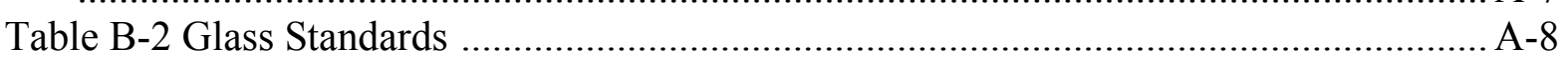




\section{LIST OF ACRONYMS}

$\begin{array}{ll}\text { ADS } & \text { Analytical Development Section } \\ \text { DWPF } & \text { Defense Waste Processing Facility } \\ \text { EDM } & \text { Electro Discharge Machining } \\ \text { EDS } & \text { Energy Dispersive Spectrometry } \\ \text { FP } & \text { Fundamental Parameter } \\ \text { HVOF } & \text { High Velocity Oxygen Fuel Sprayer } \\ \text { IC } & \text { Ion Chromatography } \\ \text { ICP-ES } & \text { Inductively Coupled Plasma Electron Spectroscopy } \\ \text { Kcps } & \text { Kilocounts per second } \\ \text { LAW } & \text { Low Activity Waste } \\ \text { MTS } & \text { Materials Technology Section } \\ \text { MS } & \text { Mass Spectrometer } \\ \text { QA } & \text { Quality Assurance } \\ \text { QAP } & \text { Quality Assurance Plan } \\ \text { QAPjP } & \text { Quality Assurance Project Plan } \\ \text { RPP } & \text { River Protection Program } \\ \text { SEM } & \text { Scanning Electron Microscopy } \\ \text { SRTC } & \text { Savannah River Technology Center } \\ \text { SRS } & \text { Savannah River Site } \\ \text { TGA } & \text { Thermal Gravimetric Analyzer } \\ \text { TTP } & \text { Task Technical Plan } \\ \text { UT } & \text { Ultrasonic Testing } \\ \text { VSL } & \text { Vitreous State Laboratory } \\ \text { WD } & \text { Wavelength Dispersive } \\ \text { XRD } & \text { X-ray Diffraction } \\ \text { XRF } & \text { X-ray Fluorescence }\end{array}$




\subsection{SUMMARY OF TESTING}

\subsection{OBJECTIVES}

The River Protection Program (RPP) low activity waste (LAW) melter design incorporates a series of bubblers used to increase convection in the molten glass. Through runs of a pilot melter at Duratek, Inc. in Columbia, Maryland, the bubblers have been identified as the major component limiting LAW melter availability, requiring frequent replacement due to corrosive degradation, primarily at the melt line.

Laboratory experiments were performed to evaluate the performance of several alloys and coatings in simulated RPP low activity waste melter vapor space and molten glass environments. The performance of the alloys and coatings was studied in order to advance our understanding of how these materials react at the melt/air interface inside the melter. The ultimate goal was to identify a material with superior performance compared to that of Inconel 693, and to deliver a bubbler sub-assembly made of that material to the RPP LAW melter pilot facility for further testing. The Task Technical and Quality Assurance Plan (TTP and QAP) for this evaluation, SRT-RPP-2000-00037, Rev. 0, was developed in response to RPP Task Specification TSP-W375-00-00032, Rev. 2.

\subsection{CONDUCT OF TESTING}

Materials that were tested were Inconel 693 (I-693), platinum-coated Inconel 693, Inconel MA 758 (MA 758), an SRTC proprietary Inconel alloy (SRTC), Inconel 690 (I-690) coated with AE 7855 and I-690 coated with Amdry 964. The materials were selected by the customer from a much larger list of alloys and coatings developed by SRTC. The alloys were nickel / chromium alloys with additions of various amounts of aluminum and yttrium, the yttrium added as a grain stabilizer. MA 758, the only mechanically alloyed material tested, was selected because it was successfully used in the RPP LAW pilot melter. Platinum-coated alloys were also successfully used in the melter. The last two metallic coatings, AE 7855 and Amdry 964, both developed for the aerospace industry, were selected in part because their thermal expansions closely match that of I-690. The platinum was electroplated onto the I-693 coupons and the other two coatings were applied with a high velocity oxygen fuel sprayer (HVOF).

The glass and feed simulants used were LAWA44 glass and the corresponding sub-envelope A1 feed developed for Hanford Tank AN-105. Target concentrations of corrosive species in the simulant glass were $0.24 \mathrm{wt} \% \mathrm{SO}_{3}$ and $0.56 \mathrm{wt} \% \mathrm{Cl}$.

The material performance testing consisted of two main experiments outlined in the TTP. Molten glass attack and melt line attack were studied using a static molten glass test. Coupons were suspended in a crucible of molten glass at the anticipated LAW melt pool temperature. Coupons were then evaluated using conventional techniques such as scanning electron microscopy (SEM) and optical metallography. 
In the second experiment, vapor space conditions of the envelope A formulation were simulated. Coupons were suspended above a crucible of simulant melter feed heated to LAW melt pool temperature. Identical sets of coupons were placed in three temperature zones of the offgas line, at $400^{\circ} \mathrm{C}, 600^{\circ} \mathrm{C}$, and $900^{\circ} \mathrm{C}$. Deposits condensed on the coupons and in the offgas line were analyzed using Ion Chromatography (IC), Inductively Coupled Plasma-Emission Spectroscopy (ICP-ES), and X-ray Fluorescence (XRF). Visual examination, XRF, XRD, SEM, and optical metallography were used to evaluate the test coupons.

Short-term vapor space testing as outlined in the TTP was attempted but did not yield usable data. In this experiment, a furnace containing melter feed was heated to LAW melt pool temperature. The offgas from the feed was pulled through a thermal gravimetric analyzer (TGA) containing a coupon of test material suspended from the TGA's weighing mechanism and held at a temperature expected in the LAW melter plenum. Changes in the weight of the coupon were tracked over several hours of exposure to the offgas. The data were then analyzed in an attempt to attribute weight losses to corrosion. The coupons, however, gained and lost weight over the time interval, presumably due to the competing processes of metal loss, metal oxidation, and offgas deposition. No clear conclusions could be drawn.

\subsection{RESULTS AND PERFORAMCE AGAINST OBJECTIVES}

The first of the two tests conducted was the molten glass study. Coupons were partially submerged in molten glass at $1150^{\circ} \mathrm{C}$ for 53 days. Because the chloride and sulfate salts are volatile, the glass was changed every day. Initial visual inspection of the coupons following exposure indicated that both the HVOF coated coupons had failed due to severe spallation of the coating. No further evaluation of these was performed. The remaining four coupons were prepared for examination using standard metallographic practices taking particular care to ensure that the ground surface remained orthogonal to the sides. Metallurgical examination of the platinum-coated coupon revealed several through-coupon cracks, therefore, this material was not included in the dimensional evaluation. Dimensional analysis was performed using a measuring microscope to determine the minimum thickness and a scanning electron microscope (SEM) to determine the depth of internal attack. The ultimate goal was to determine total degradation, which is the sum of the material loss and internal attack resulting on one side of the coupon. SEM photographs also revealed some insight into how these materials performed, i.e. oxide stability, in the molten glass and vapor regions. Material loss, depth of internal attack, and total degradation are presented in the table below. Degradation measurements were made for the glass/vapor interface region but are not included in the table. Molten glass level fluctuations made accurate dimensional measurement difficult. These measurements are reported later in this document. 
WSRC-TR-2002-00588, REV. 0

SRT-RPP-2002-00283. REV. 0

Table 1-1 Summary of Data Used to Calculate Total Degradation from One Side of the Coupons

\begin{tabular}{|c|c|c|c|c|c|c|c|c|c|c|}
\hline \multirow{3}{*}{ Material } & \multicolumn{4}{|c|}{ Internal Depth of Attack $(\mu \mathrm{m})$} & \multicolumn{2}{|c|}{$\begin{array}{l}\text { Total Material } \\
\text { Loss }(\mu \mathrm{m})^{*}\end{array}$} & \multicolumn{4}{|c|}{\begin{tabular}{|c|c|}
$\begin{array}{c}\text { Total Degradation } \\
(\mu \mathrm{m})^{* *}\end{array}$ & $\begin{array}{c}\text { Total Degradation } \\
(\mu \mathrm{m})^{* * *}\end{array}$
\end{tabular}} \\
\hline & \multicolumn{2}{|c|}{ Glass } & \multicolumn{2}{|c|}{ Vapor $^{\xi}$} & \multirow[t]{2}{*}{ Glass } & \multirow[t]{2}{*}{ Vapor $^{\xi}$} & \multirow[t]{2}{*}{ Glass } & \multirow[t]{2}{*}{ Vapor $^{\xi}$} & \multirow[t]{2}{*}{ Glass } & \multirow[t]{2}{*}{ Vapor $^{\xi}$} \\
\hline & Max & Avg & Max & Avg & & & & & & \\
\hline SRTC & 233 & 137 & 77 & 73 & 241 & 216 & 353 & 185 & 257 & 181 \\
\hline MA 758 & 443 & 436 & 372 & 236 & 86 & 13 & 486 & 378 & 479 & 243 \\
\hline $\mathrm{I}-693$ & 766 & 480 & 326 & 204 & 516 & 315 & 1024 & 484 & 737 & 362 \\
\hline
\end{tabular}

* Material loss from both sides of the coupon

** Total degradation using maximum internal depth of attack

*** Total degradation using average internal depth of attack

$\xi \quad$ 'Vapor' denotes measurements in the vapor space above the molten glass

The final ranking from the molten glass test is based on total degradation, which is the sum of material loss and internal attack. Considering total degradation, the SRTC alloy was the most resistant to corrosive attack in both the molten glass and vapor environments. However when evaluating only material loss, the MA 758 was the most resistant to corrosive attack in both regions. Alloy MA 758 had the most uniform oxide layer and this is reflected in its low material loss, however, the oxide did not act as a good diffusion barrier as indicated by the depth of the internal attack. All of the alloys exhibited evidence of chromium depletion generally to the depth of the internal attack. No attempt was made to quantify the depth of chromium depletion or grain growth. Grain boundary area can affect diffusion and corrosion rates. Inconel 693 alloy was least resistant to attack in both environments.

Vapor space testing was performed in a separate experimental apparatus that contained three specific temperature zones where coupons of the same six alloys were placed. The temperatures were 400,600 , and $900^{\circ} \mathrm{C}$. The 900 and $400^{\circ} \mathrm{C}$ temperatures represented the maximum and minimum plenum temperatures expected in the LAW melter during feeding and idling times. The $600^{\circ} \mathrm{C}$ temperature zone was added by SRTC because this is the region where chloride and sulfate salt deposition, which generally occurs below $850^{\circ} \mathrm{C}$, has the greatest effect on nickel-based alloys.

The melter feed simulant was changed out twice a day to maximize the amount of corrosive species in contact with the coupons. During the initial phase of this 73-day test a mass spectrometer was coupled to the furnace outlet. Large amounts of $\mathrm{CO}_{2}$ and $\mathrm{NO}_{\mathrm{X}}$ were observed, as was a significant amount of $\mathrm{HCl}$. This was also confirmed during the limited TGA runs. Synergistic corrosive effects exist with the presence of both deposited salts and $\mathrm{HCl}$ gas, but the effects cannot be differentiated by this test.

Degradation in the $400^{\circ} \mathrm{C}$ zone was minimal. Degradation in the $900^{\circ} \mathrm{C}$ region was higher but not as severe as that in the $600^{\circ} \mathrm{C}$ region. IC and ICP data showed the highest concentration of aggressive species on the coupons in the $600^{\circ} \mathrm{C}$ region, which was consistent with the higher degree of corrosive attack. However, the presence of $\mathrm{HCl}$ may 
result in corrosive attack in all temperature zones and it would be impossible to differentiate degradation from the competing mechanisms. Another significant observation was that the degradation observed in the $900{ }^{\circ} \mathrm{C}$ region of the vapor space test was considerably less than the degradation observed in the vapor space from the molten glass test, which was maintained at $1150{ }^{\circ} \mathrm{C}$. Based on the observed metal loss and internal attack the following relative ranking was developed.

Table 1-2 Qualitative Ranking of Long-Term Vapor Space Coupons

\begin{tabular}{|l|l|l|l|}
\hline Material Ranking & $400^{\circ} \mathrm{C}$ Zone & $600^{\circ} \mathrm{C}$ Zone & $900^{\circ} \mathrm{C}$ Zone \\
\hline 1 & Pt-Coated I-693 & Pt-Coated I-693 & I-693 \\
\hline 2 & SRTC Alloy/I-693* & MA 758 & Pt-Coated I-693 \\
\hline 3 & SRTC Alloy/I-693* & I-693 & SRTC Alloy \\
\hline 4 & MA 758 & SRTC Alloy & MA 758 \\
\hline
\end{tabular}

*Material performance was basically identical.

\subsection{QUALITY R EQUIREMENTS}

This work was conducted in accordance with the RPP-WTP QA requirements specified for work conducted by SRTC as identified in DOE IWO MOSRLE60. SRTC has provided matrices to WTP demonstrating compliance of the SRTC QA program with the requirements specified by WTP. Specific information regarding the compliance of the SRTC QA program with RW-0333P, Revision 10, NQA-1 1989, Part 1, Basic and Supplementary Requirements and NQA-2a 1990, Subpart 2.7 is contained in these matrices.

As stated in the TTP for this task, data that was generated will not be used for environmental regulatory purposes. Per the "Quality Assurance Project Plan (QAPjP) for Testing Programs Generating Environmental Regulatory Data”, PL-24590-QA00001, Rev. 0, the quality control for analytical data specified in the aforementioned QAPjP was not applicable. The following analytical protocol was followed for this task.

Analyses were provided by SRTC's Analytical Development Section (ADS) on a "routine" QA/QC level. Routine Level is for general R\&D support. ADS maintains a written method or instrument procedure for all Routine Level analyses, and the results for most methods are recorded. Quality Control is addressed through ADS's Measurement Control Program (MCP) for analytical services. Quality Control data is routinely tracked and evaluated. The ADS QC program tracks long term system performance of the Measurement Systems. These systems include instruments, standards and personnel. These records are available and auditable, but were submitted with sample analysis results. Measuring and test equipment used in the testing was in compliance with WSRC QA requirements.

\subsection{ISSUES}

Generally molten glass attack is the focus of testing programs because it is one of the more aggressive environments. However, vapor corrosion, especially in the presence of mixed gases and salts, can be catastrophic. Melter and offgas components maintained at or cycled 
WSRC-TR-2002-00588, REV. 0

SRT-RPP-2002-00283. REV. 0

through critical temperature ranges can suffer severe degradation in very short time periods. This was the case for several critical components in the Defense Waste Processing Facility (DWPF) at SRS. These components were identified and modified during cold runs (nonradioactive operations). System modifications during radioactive operations would have presented a major engineering challenge and would have been extremely difficult to remotely install.

Similar issues are of concern for the RPP LAW melter system. The synergistic affects of $\mathrm{HCl}$ and chloride and sulfate salts can be extremely corrosive as shown in the current testing program. Some degradation was even seen in the $400^{\circ} \mathrm{C}$ region. It is extremely difficult to model the complex environment inside the plenum and off gas system. Furthermore it is extremely difficult to locate coupons precisely in a full size melter system where the attack may occur therefore, laboratory testing of promising materials, alloys and coatings, is necessary in order identify areas of concern and predict performance. This will maximize service lives of critical components, minimize worker exposure, and ultimately reduce operating costs.

Additional material testing in the molten glass region is necessary. Commercially available materials have shown some promise but work is still needed. Because this is a very specific environment and a very limited market, commercial vendors are not willing to expend much effort in developing more corrosion resistant materials. The use of platinum coatings is one option that has shown promise in actual melter tests and should be pursued. The selection of the optimal base metal, diffusion barriers, platinum alloy composition, surface finish, porosity and thermo-physical properties should be evaluated in order to optimize performance of the platinum coating. Barrier and functionally graded coatings are applied in the coating industry to optimize mechanical properties and corrosion resistance. Application of a barrier coating could be applied to the Inconel substrate before the corrosion resistant platinum coating to minimize diffusion of oxygen. Mechanical properties at ambient and elevated temperatures, along with oxidation and corrosion resistance must be evaluated to assess performance. Testing comparing the barrier-coated coupon with other platinum, platinum alloys, and platinum thermal spray coatings should then be performed. Alloy development is also possible but would require a longer-term effort. With a good understanding of the glass chemistry it would be possible to develop an alloy with increased corrosion resistance for this particular glass chemistry.

Total degradation in the molten glass tests was based on metal loss and internal attack. Close examination of components from the Duratek melter should be performed to correlate test data with actual component degradation. This would involve a thorough metallurgical evaluation of each failed melter component.

\subsection{CD-ROM ENCLOSURES}

N/A

Page 5 of 40 


\subsection{DISCUSSI ON}

\subsection{INTRODUC TION}

The River Protection Program (RPP) low activity waste (LAW) melter design incorporates a series of bubblers used to increase convection in the molten glass. Through runs of a pilot melter at Duratek, Inc. in Columbia, Maryland, the bubblers have been identified as the major component limiting LAW melter availability, requiring frequent replacement due to corrosive degradation, primarily at the melt line.

Laboratory experiments were performed to evaluate the performance of several alloys and coatings in simulated RPP low activity waste melter vapor space and molten glass environments. The performance of the alloys and coatings was studied in order to advance our understanding of how these materials react at the melt/air interface inside the melter. The ultimate goal was to identify a material with superior performance compared to that of Inconel 693, and to deliver a bubbler sub-assembly made of that material to the RPP LLW melter pilot facility for further testing. The Task Technical and Quality Assurance Plan (TTP and QAP) for this evaluation, SRT-RPP-2000-00037, Rev. 0, was developed in response to RPP Task Specification TSP-W375-00-00032, Rev. 2.

Materials that were tested were Inconel 693 (I-693), platinum-coated Inconel 693, Inconel MA 758 (MA 758), an SRTC proprietary Inconel alloy (SRTC), Inconel 690 (I-690) coated with AE 7855 and I-690 coated with Amdry 964. The materials were selected by the customer from a much larger list of alloys and coatings developed by SRTC. The alloys were nickel / chromium alloys with additions of various amounts of aluminum and yttrium, the yttrium added as a grain stabilizer. MA 758, the only mechanically alloyed material tested, was selected because it was successfully used in the RPP LAW pilot melter.

Platinum-coated alloys were also successfully used in the melter. The last two metallic coatings, AE 7855 and Amdry 964, both developed for the aerospace industry, were selected in part because their thermal expansions closely match that of I-690. The platinum was electroplated onto the I-693 coupons and the other two coatings were applied with a high velocity oxygen fuel sprayer (HVOF).

The glass and feed simulants used were LAWA44 glass and the corresponding sub-envelope A1 feed developed for Hanford Tank AN-105. Target concentrations of corrosive species in the simulant glass were $0.24 \mathrm{wt} \% \mathrm{SO}_{3}$ and $0.56 \mathrm{wt} \% \mathrm{Cl}$.

The materials performance testing consisted of two main experiments outlined in the TTP. Molten glass attack and melt line attack were studied using a static molten glass test. Coupons were suspended in a crucible of molten glass at the anticipated LAW melt pool temperature. Coupons were then evaluated using conventional techniques such as scanning electron microscopy (SEM) and optical metallography.

In the second experiment, vapor space conditions of the envelope A formulation were simulated. Coupons were suspended above a crucible of simulant melter feed heated to LAW melt pool temperature. Identical sets of coupons were placed in three temperature 
WSRC-TR-2002-00588, REV. 0

SRT-RPP-2002-00283. REV. 0

zones of the offgas line, at $400^{\circ} \mathrm{C}, 600^{\circ} \mathrm{C}$, and $900^{\circ} \mathrm{C}$. Deposits which condensed on the coupons and in the offgas line were analyzed using ion chromatography (IC), Inductively Coupled Plasma-Emission Spectroscopy (ICP-ES), and X-ray Fluorescence (XRF). Visual examination, XRF, XRD, SEM, and optical metallography were used to evaluate the test coupons.

Short-term vapor space testing as outlined in the TTP was conducted but did not yield usable data. In this experiment, a furnace containing melter feed was heated to LAW melt pool temperature. The offgas from the feed was pulled through a thermal gravimetric analyzer (TGA) containing a coupon of test material suspended from the TGA's weighing mechanism and held at a temperature expected in the LAW melter plenum. Changes in the weight of the coupon were tracked over several hours of exposure to the offgas. The data were then analyzed in an attempt to attribute weight losses to corrosion. The coupons, however, gained and lost weight over the time interval, presumably due to the competing processes of metal loss, metal oxidation, and offgas deposition. No clear conclusions could be drawn from the current study. Additional modifications and development to the test method would be needed to obtain relevant data.

\subsection{QUALITY ASSURANCE}

This work was conducted in accordance with the RPP-WTP QA requirements specified for work conducted by SRTC as identified in DOE IWO MOSRLE60. SRTC has provided matrices to WTP demonstrating compliance of the SRTC QA program with the requirements specified by WTP. Specific information regarding the compliance of the SRTC QA program with RW-0333P, Revision 10, NQA-1 1989, Part 1, Basic and Supplementary Requirements and NQA-2a 1990, Subpart 2.7 is contained in these matrices.

As stated in the TTP for this task, data that was generated will not be used for environmental regulatory purposes. Per the "Quality Assurance Project Plan (QAPjP) for Testing Programs Generating Environmental Regulatory Data", PL-24590-QA00001, Rev. 0, the quality control for analytical data specified in the aforementioned QAPjP was not applicable. The following analytical protocol was followed for this task.

Analyses were provided by SRTC's Analytical Development Section (ADS) on a "routine" QA/QC level. Routine Level is for general R\&D support. ADS maintains a written method or instrument procedure for all Routine Level analyses, and the results for most methods are recorded. Quality Control is addressed through ADS's Measurement Control Program (MCP) for analytical services. Quality Control data is routinely tracked and evaluated. The ADS QC program tracks long term system performance of the Measurement Systems. These systems include instruments, standards and personnel. These records are available and auditable, but were submitted with sample analysis results. Measuring and test equipment used in the testing was in compliance with WSRC QA requirements. 
WSRC-TR-2002-00588, REV. 0

SRT-RPP-2002-00283. REV. 0

\subsection{CONDUCT OF TESTING}

\subsubsection{Materials}

\subsubsection{Glass and Feed Characterization}

The melter glass and feed used in the material evaluation experiments were LAW subenvelope A1 simulant sent to SRTC by the Vitreous State Laboratory (VSL) at the Catholic University of America. VSL personnel made the simulant glass in their DM1200 melter using one of two batches of feed purchased from Optima Chemical Corporation. Table 3-1 contains the target composition of the glass.

\section{Table 3-1 LAW Sub-Envelope A1 Simulant Glass Composition}

\begin{tabular}{|l|c|}
\hline Glass Oxide & Weight Percent \\
\hline $\mathrm{Al}_{2} \mathrm{O}_{3}$ & 6.18 \\
\hline $\mathrm{B}_{2} \mathrm{O}_{3}$ & 8.98 \\
\hline $\mathrm{CaO}$ & 1.99 \\
\hline $\mathrm{Cr}_{2} \mathrm{O}_{3}$ & 0.02 \\
\hline $\mathrm{Cs}_{2} \mathrm{O}$ & 0.14 \\
\hline $\mathrm{Fe}_{2} \mathrm{O}_{3}$ & 6.96 \\
\hline $\mathrm{K}_{2} \mathrm{O}$ & 0.44 \\
\hline $\mathrm{MgO}$ & 1.99 \\
\hline $\mathrm{Na}_{2} \mathrm{O}$ & 20.02 \\
\hline $\mathrm{NiO}_{\mathrm{O}}$ & 0.00 \\
\hline $\mathrm{SiO}$ & 44.44 \\
\hline $\mathrm{TiO}_{2}$ & 1.99 \\
\hline $\mathrm{ZnO}$ & 2.96 \\
\hline $\mathrm{ZrO}$ & 2.98 \\
\hline $\mathrm{Cl}$ & 0.56 \\
\hline $\mathrm{F}$ & 0.02 \\
\hline $\mathrm{P}_{2} \mathrm{O}_{5}$ & 0.07 \\
\hline $\mathrm{SO}$ & 0.24 \\
\hline $\mathrm{Total}$ & 100.00 \\
\hline
\end{tabular}

NOTE:

- Potassium iodide is spiked into the feed at VSL at a level corresponding to $0.1 \mathrm{wt} \%$ iodine in the glass if it were all retained.

- $\quad$ Cadmium and selenium are spiked at $1124 \mathrm{mg} / \mathrm{l}$ and $899 \mathrm{mg} / \mathrm{l}$, respectively, in the simulant, which corresponds to 0.1 wt $\%$ of each oxide in the glass.

- $\quad$ Ref: LAW A1 Integrated Off-Gas Tests on the DM1200 Test Plan. VSL-01T8800-2, Rev. 1, Vitreous State Laboratory, The Catholic University of America, DC 20064.

After receipt of the glass at SRTC, a three-day study was performed to determine the rates of evolution of corrosive species from the molten glass when the glass was heated in mullite crucibles. Table 3-2 contains results obtained from XRF analysis of the glass prior to heating and after one, two, and three days at $1150^{\circ} \mathrm{C}$. 
WSRC-TR-2002-00588, REV. 0

SRT-RPP-2002-00283. REV. 0

Table 3-2 Results of Three-Day Glass Compositional Study

Composition (Wt \%)

\begin{tabular}{|l|c|c|c|c|c|c|c|c|}
\hline Sample & $\mathbf{A l}_{\mathbf{2}} \mathbf{O}_{\mathbf{3}}$ & $\boldsymbol{B}_{\mathbf{2}} \mathbf{O}_{\mathbf{3}}$ & $\mathbf{C a O}$ & $\mathbf{C r}_{\mathbf{2}} \mathbf{O}_{\mathbf{3}}$ & $\mathbf{F e}_{\mathbf{2}} \mathbf{O}_{\mathbf{3}}$ & $\mathbf{K}_{\mathbf{2}} \mathbf{O}$ & $\mathbf{M g O}$ & $\mathbf{N a}_{\mathbf{2}} \mathbf{O}$ \\
\hline As-Received & 6.06 & 9.82 & 2.01 & 0.08 & 7.57 & 0.52 & 1.63 & 21.48 \\
\hline $\mathbf{1 d a y @ 1 1 5 0} \mathbf{C} \mathbf{C}$ & 6.35 & 9.92 & 2.00 & 0.08 & 7.49 & 0.52 & 1.65 & 20.87 \\
\hline $\mathbf{2 d a y @ 1 1 5 0} \mathbf{C}$ & 6.58 & 9.69 & 2.05 & 0.09 & 7.80 & 0.55 & 1.60 & 19.80 \\
\hline $\mathbf{3 d a y @ 1 1 5 0 ^ { \mathbf { 0 } } \mathbf { C }}$ & 6.85 & 9.60 & 2.00 & 0.08 & 7.58 & 0.55 & 1.61 & 19.88 \\
\hline
\end{tabular}

\begin{tabular}{|l|c|c|c|c|c|c|c|}
\hline Sample & $\mathbf{S i O}_{\mathbf{2}}$ & $\mathbf{T i O}_{\mathbf{2}}$ & $\mathbf{Z n O}$ & $\mathbf{Z r O}_{\mathbf{2}}$ & $\mathbf{P}_{\mathbf{2}} \mathbf{O}_{\mathbf{5}}$ & $\mathbf{S O}_{\mathbf{3}}$ & $\mathbf{C l}$ \\
\hline As-Received & 41.68 & 2.06 & 3.24 & 2.91 & 0.08 & 0.31 & 0.29 \\
\hline $\mathbf{1 d a y} @ \mathbf{1 1 5 0} \mathbf{0}^{\mathbf{C}}$ & 42.34 & 2.03 & 3.19 & 2.86 & 0.08 & 0.25 & 0.11 \\
\hline $\mathbf{2 d a y} @ \mathbf{1 1 5 0}^{\mathbf{0}} \mathbf{C}$ & 42.64 & 2.12 & 3.35 & 3.04 & 0.08 & 0.22 & 0.07 \\
\hline $\mathbf{3 d a y @ 1 1 5 0 ^ { \mathbf { } } \mathbf { C }}$ & 42.98 & 2.09 & 3.22 & 2.92 & 0.08 & 0.20 & 0.04 \\
\hline
\end{tabular}

$\mathrm{B}_{2} \mathrm{O}_{3}$ was determined by ICP-ES after sodium peroxide / sodium hydroxide digestion.

The data for phosphate, sulfate, and chloride are plotted in Figure 3-1, Figure 3-2, and Figure 3-3. See Appendix B for further details on instrument parameters and sample preparation. 
WSRC-TR-2002-00588, REV. 0

SRT-RPP-2002-00283. REV. 0

Phosphate Volatility in RPP Envelop A Glass

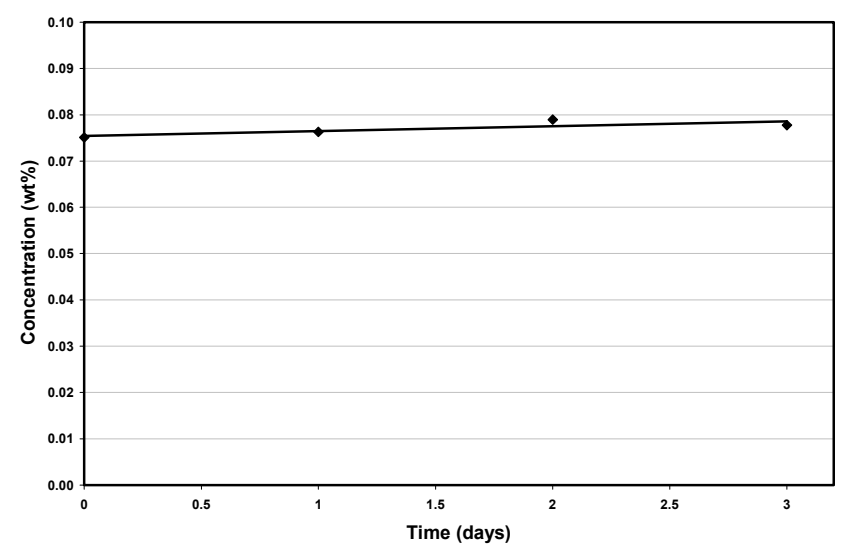

Figure 3-1 Plot of Phosphate Concentration in Simulant Glass Versus Time at $1150^{\circ} \mathrm{C}$

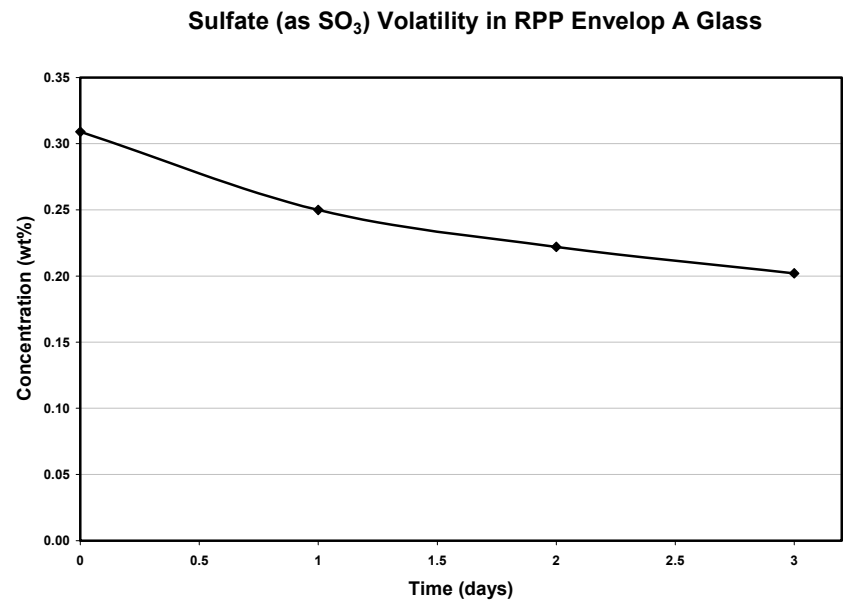

Figure 3-2 Plot of Sulfate Concentration in Simulant Glass Versus Time at $1150^{\circ} \mathrm{C}$

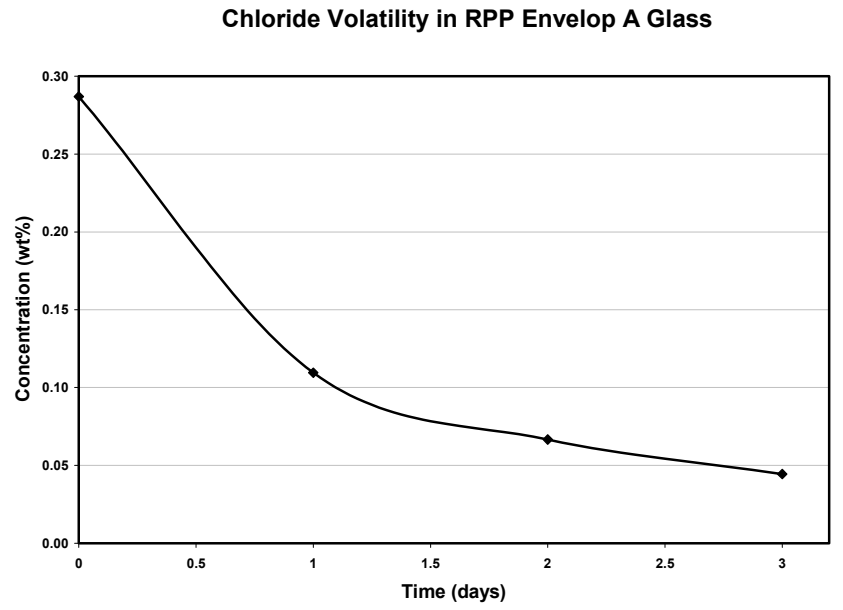

Figure 3-3 Plot of Chloride Concentration in Simulant Glass Versus Time at $1150^{\circ} \mathrm{C}$ 
VSL personnel mixed the second feed batch with sugar (anti-foaming agent) and shipped it to SRTC. Table 3-3 and Table 3-4 contain the composition of the simulant waste and the composition of the additives and glass formers added to the simulant on a one liter basis. See Appendix A for additional batching information.

Table 3-3 LAW Sub-Envelope A1 Simulant Feed Composition, 1 Liter Basis

\begin{tabular}{|c|c|}
\hline Batch Chemical & Target Weight $(\mathrm{g})$ \\
\hline Water & 284.43 \\
\hline $\mathrm{Al}\left(\mathrm{NO}_{3}\right)_{3}-9 \mathrm{H}_{2} \mathrm{O}, 60 \%$ sol. & 387.68 \\
\hline $\mathrm{Al}(\mathrm{OH})_{3}$ & 46.11 \\
\hline $\mathrm{Ca}\left(\mathrm{NO}_{3}\right)_{2}-4 \mathrm{H}_{2} \mathrm{O}$ & 0.34 \\
\hline $\mathrm{Na}_{2} \mathrm{CrO}_{4}-4 \mathrm{H}_{2} \mathrm{O}$ & 0.76 \\
\hline $\mathrm{CsNO}_{3}$ & 2.48 \\
\hline $\mathrm{Fe}\left(\mathrm{NO}_{3}\right)_{3}-9 \mathrm{H}_{2} \mathrm{O}$ & 0.14 \\
\hline $\mathrm{KOH}$ & 7.71 \\
\hline $\mathrm{NaOH}, 50 \%$ sol. $\mathrm{D}=1.53$ & 440.63 \\
\hline $\mathrm{Ni}\left(\mathrm{NO}_{3}\right)_{3}-6 \mathrm{H}_{2} \mathrm{O}$ & 0.14 \\
\hline $\mathrm{SiO}_{2}$ & 0.33 \\
\hline $\mathrm{NaCl}$ & 11.55 \\
\hline $\mathrm{NaF}$ & 0.68 \\
\hline $\mathrm{Na}_{3} \mathrm{PO}_{4}-12 \mathrm{H}_{2} \mathrm{O}$ & 4.53 \\
\hline $\mathrm{Na}_{2} \mathrm{SO}_{4}$ & 4.31 \\
\hline $\mathrm{NaNO}_{2}$ & 134.31 \\
\hline $\mathrm{Na}_{2} \mathrm{CO}_{3}$ & 21.09 \\
\hline $\mathrm{NH}_{4} \mathrm{NO}_{3}$ & 10.98 \\
\hline $\mathrm{Na}_{2}$ EDTA-2 $\mathrm{H}_{2} \mathrm{O}(\mathrm{C} 10)$ & 4.72 \\
\hline $\mathrm{Na}_{3}$ HEDTA $41 \%$ sol. (C10) & 13.34 \\
\hline Sodium Acetate (C2) & 4.92 \\
\hline Sodium Formate (C1) & 3.06 \\
\hline Sodium Oxalate (C2) & 1.04 \\
\hline Glycolic Acid (C2) & 2.72 \\
\hline Total Weight & 1388.55 \\
\hline
\end{tabular}

NOTE:

- Potassium iodide is spiked into the feed at VSL at a level corresponding to $0.1 \mathrm{wt} \%$ iodine in the glass if it were all retained.

- $\quad$ Cadmium and selenium are spiked at $1124 \mathrm{mg} / \mathrm{l}$ and $899 \mathrm{mg} / 1$, respectively, in the simulant, which corresponds to 0.1 $\mathrm{wt} \%$ of each oxide in the glass.

- Ref: LAW A1 Integrated Off-Gas Tests on the DM1200 Test Plan. VSL-01T8800-2, Rev. 1, Vitreous State Laboratory, The Catholic University of America, DC 20064. 
WSRC-TR-2002-00588, REV. 0

SRT-RPP-2002-00283. REV. 0

Table 3-4 LAW Sub-Envelope A1 Glass Former Additives per 1 Liter of Simulant Feed

\begin{tabular}{|c|c|}
\hline Glass Former Additive & Target Weight $(\mathrm{g})$ \\
\hline Kyanite $\left(\mathrm{Al}_{2} \mathrm{SiO}_{5}\right) 325 \mathrm{Mesh}$ (Kyanite Mining) (g) & 42.46 \\
\hline $\mathrm{H}_{3} \mathrm{BO}_{3}$ (US Borax - Technical Granular) (g) & 200.66 \\
\hline Wollanstonite NYAD 325 Mesh (NYCO Minerals) (g) & 52.14 \\
\hline $\mathrm{Fe}_{2} \mathrm{O}_{3}(97 \%$ Alfa $)(\mathrm{g})$ & 81.65 \\
\hline Olivine $\left(\mathrm{Mg}_{2} \mathrm{SiO}_{4}\right) 325 \mathrm{Mesh}(\# 180$ Unimin) $(\mathrm{g})$ & 51.92 \\
\hline $\mathrm{SiO}_{2}($ Sil-co-Sil 75 US Silica) $(\mathrm{g})$ & 466.91 \\
\hline $\mathrm{TiO}_{2}$ (Rutile Airfloated Chemaloy) (g) & 25.86 \\
\hline $\mathrm{ZnO}$ (KADOX - 920 Zinc Corp. of America) (g) & 36.8 \\
\hline Zircon $\mathrm{ZrSiO}_{4}$ (Flour) Mesh 325 (AM Mineral) (g) & 55.61 \\
\hline Addition of Sucrose as Reductant (nominal) (g) & 69.48 \\
\hline$+\mathrm{Na}_{2} \mathrm{SO}_{4}$ (from recycled off-gas) $(\mathrm{g})$ & 1.08 \\
\hline Total Weight of Glass Formers & 1085 \\
\hline
\end{tabular}

- Ref: LAW A1 Integrated Off-Gas Tests on the DM1200 Test Plan. VSL-01T8800-2, Rev. 1, Vitreous State Laboratory, The Catholic University of America, DC 20064.

The simulant melter feed sent from VSL was analyzed using Inductively Coupled Plasma Electron Spectroscopy (ICP-ES) to measure cation concentrations. Table 3-5 contains the measured data converted to oxide weight percent and target amounts reported by VSL.

Table 3-5 LAW Sub-Envelope A1 Simulant Feed ICP Data

\begin{tabular}{|l|c|c|c|}
\hline & Target (wt\%) & $\mathrm{Na}_{2} \mathrm{O}_{2}$ Fusion (wt\%) & $\mathrm{Li}_{2} \mathrm{~B}_{4} \mathrm{O}_{7}$ Fusion (wt\%) \\
\hline $\mathrm{Al}_{2} \mathrm{O}_{3}$ & 6.18 & 4.94 & 4.97 \\
\hline $\mathrm{B}_{2} \mathrm{O}_{3}$ & 8.98 & 8.32 & \\
\hline $\mathrm{CaO}$ & 1.99 & & 1.46 \\
\hline $\mathrm{Cr}_{2} \mathrm{O}_{3}$ & 0.02 & & 0.01 \\
\hline $\mathrm{Cs}_{2} \mathrm{O}$ & 0.14 & 4.71 & \\
\hline $\mathrm{Fe}_{2} \mathrm{O}_{3}$ & 6.96 & & 4.70 \\
\hline $\mathrm{K}_{2} \mathrm{O}$ & 0.44 & 0.14 & 0.51 \\
\hline $\mathrm{MgO}$ & 1.99 & & 0.15 \\
\hline $\mathrm{Na}_{2} \mathrm{O}$ & 20.02 & & 17.51 \\
\hline $\mathrm{NiO}_{\mathrm{SiO}}$ & 0.00 & 29.63 & 0.01 \\
\hline $\mathrm{TiO}_{2}$ & 44.44 & 1.65 & 30.38 \\
\hline $\mathrm{ZnO}^{\mathrm{ZnO}}$ & 1.99 & 2.44 & 1.70 \\
\hline $\mathrm{Cl}_{2}$ & 2.96 & 1.30 & 2.48 \\
\hline $\mathrm{F}$ & 2.98 & & 1.37 \\
\hline $\mathrm{P}_{2} \mathrm{O}_{5}$ & 0.56 & & \\
\hline $\mathrm{SO}_{3}$ & 0.02 & & \\
\hline
\end{tabular}

- Ref: LAW A1 Integrated Off-Gas Tests on the DM1200 Test Plan. VSL-01T8800-2, Rev. 1, Vitreous State Laboratory, The Catholic University of America, DC 20064.

- Blank spaces denote no analysis for those species. 
Ion chromatography (IC) was used to measure the concentrations of the corrosive species in an undigested sample. Table 3-6 contains both the measured data and target amounts based on a recipe reported by VSL.

Table 3-6 LAW Sub-Envelope A1 Simulant Feed IC Data

\begin{tabular}{|l|c|c|}
\hline & Recipe $(\mu \mathrm{g} / \mathrm{g})$ & Measured $(\mu \mathrm{g} / \mathrm{g})$ \\
\hline $\mathrm{F}$ & 179 & 190 \\
\hline $\mathrm{Cl}$ & 4078 & 3280 \\
\hline $\mathrm{PO}_{4}$ & 659 & 800 \\
\hline $\mathrm{SO}_{4}$ & 1696 & 1950 \\
\hline
\end{tabular}

- Ref: LAW A1 Integrated Off-Gas Tests on the DM1200 Test Plan. VSL-01T8800-2, Rev. 1, Vitreous State Laboratory, The Catholic University of America, DC 20064.

The melter feed was also characterized using a Setaram Model Setsys 16/18 Thermogravimetric Analyzer (TGA) coupled to a Balzers Model Quadrupole QMS200 mass spectrometer (MS). A $50 \mathrm{mg}$ sample of the simulant slurry was heated to $1100^{\circ} \mathrm{C}$ in the TGA at a rate of $20^{\circ} \mathrm{C} / \mathrm{min}$. The sample chamber was purged with air at a rate of $35 \mathrm{ml} / \mathrm{min}$. Figure 3-4 is a plot of weight loss versus time. The majority of the mass loss occurred within 30 minutes between $100^{\circ} \mathrm{C}$ and $700^{\circ} \mathrm{C}$. Some additional mass loss may have occurred if the test were run longer. This mass loss would be expected to be small.

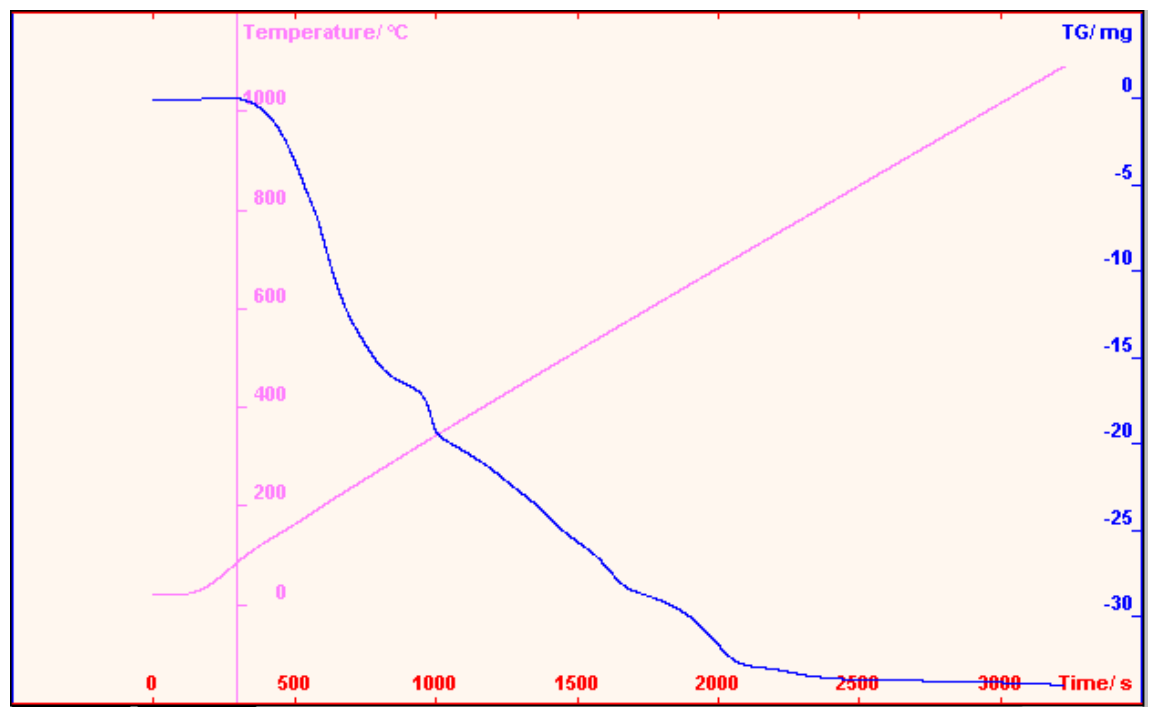

Figure 3-4 TGA Plot of Weight Loss Vs. Time for LAW Melter Feed Simulant Slurry

A mass spectrometer inserted in the TGA offgas line gathered compositional data. The MS was later used to characterize the evolved gases from the long-term vapor space experiment. Only a relatively small amount of $\mathrm{Na}_{2} \mathrm{SO}_{4}$ salt was detected, most likely because the offgas was cooled to below $200^{\circ} \mathrm{C}$ prior to entering the mass spec in order to protect the instrument. Consequently salts present in the offgas would have deposited in the heated capillary transfer line prior to MS detection. Figure 3-5 shows the relative amounts of corrosive species detected when a fresh crucible of melter feed simulant was placed in the $1150^{\circ} \mathrm{C}$ furnace. 
WSRC-TR-2002-00588, REV. 0

SRT-RPP-2002-00283. REV. 0

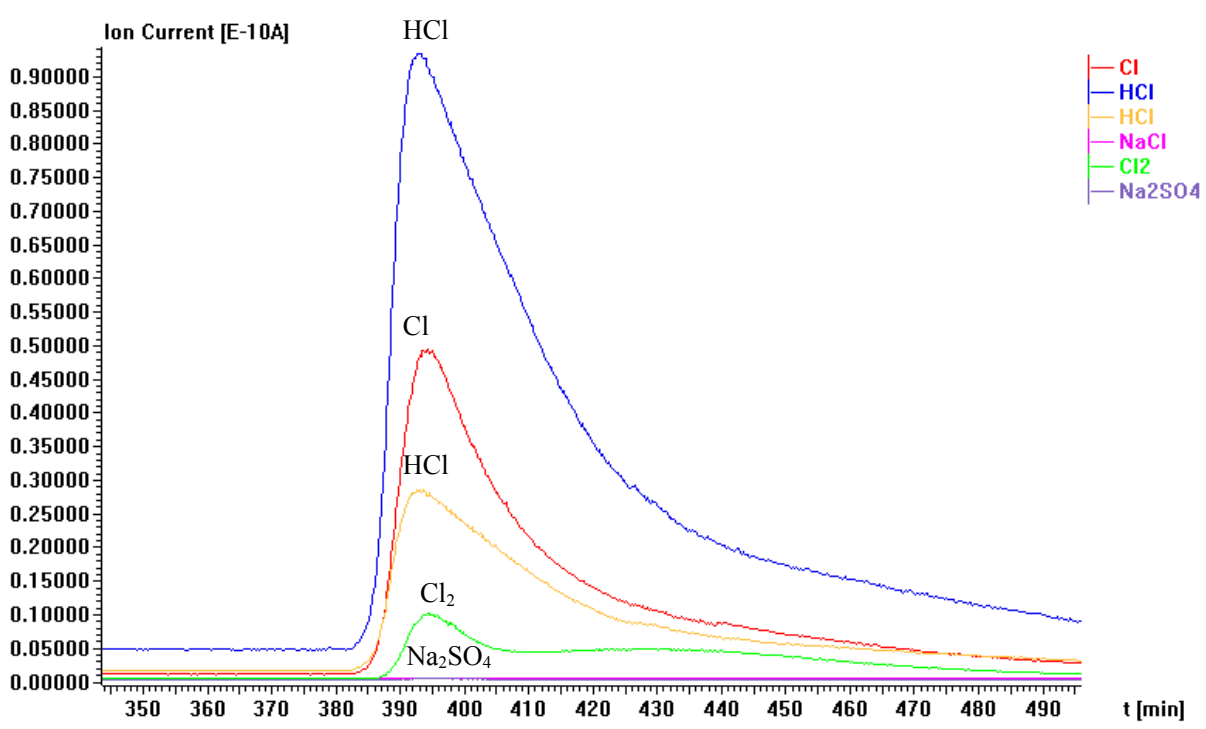

Figure 3-5 Mass Spec Data Identifying Offgas Components Released from Simulant

Lastly, the sulfur, chlorine, and phosphorous content of VSL melter feed vitrified in a mullite crucible was compared to that produced in a 95/5 platinum/gold crucible. The experiment was conducted to determine if the mullite absorbed the species or if it affected the rate of evolution of the species. Table 3-7 contains the comparative data. XRF was used to analyze the glass. See Appendix A for complete data and experimental procedure.

Table 3-7 Mullite vs. Platinum Crucible Test Data

\begin{tabular}{|l|l|l|l|}
\hline & $\mathrm{Cl}(\mathrm{kcps})$ & $\mathrm{P}(\mathrm{kcps})$ & $\mathrm{S}(\mathrm{kcps})$ \\
\hline Envelope A Feed Stock & & & \\
\hline 1 dav in mullite $0.1150^{\circ} \mathrm{C}$ & 0.9851 & 0.4115 & 0.5141 \\
\hline dav in mullite $01150^{\circ} \mathrm{C}$ & 0.9451 & 0.4048 & 0.4900 \\
\hline Average & 0.9651 & 0.4082 & 0.5021 \\
\hline 1 dav in Pt a $1150^{\circ} \mathrm{C}$ & 0 & & \\
\hline 1 dav in Pt $01150^{\circ} \mathrm{C}$ & 0 & 0.5556 & 0.9970 \\
\hline Average & 0 & 0.5443 & 0.8808 \\
\hline
\end{tabular}

Note: The crucible material itself was found to have essentially no $\mathrm{S}$ or $\mathrm{Cl}$. P peak measured at $0.4357 \mathrm{kcps}$.

After 24 hours at $1150^{\circ} \mathrm{C}$, nearly twice the amount of sulfur was found in the glass melted in the platinum crucibles than in the glass melted in the mullite crucibles. Additionally, a significant amount of chlorine was found in the glass from the mullite crucibles while none was detected in the glass from the platinum crucibles.

A possible explanation for the difference in sulfur is that the mullite material partially absorbs the sulfur. The mullite may also interact with the chlorine in a similar manner to slow the rate of evolution from the glass. This assumption is based on the fact that no chlorine was detected in glass melted in a mullite crucible held at temperature for three days. 
For the purposes of the long-term vapor space experiment, the differences in sulfur and chlorine content after melting are assumed to have no bearing on the comparative results and conclusions of the study. All coupons in each temperature region in the experiment were exposed to the same amounts of chlorine and sulfur and therefore can be compared to each other. The amounts of chlorine and sulfur released were maximized by frequent changeout of the crucibles of melter feed.

\subsubsection{Coupon pre paration}

Six materials were evaluated in the material testing. Coupons of Inconel 693, Inconel MA 758 , and SRTC alloys were initially sectioned from bar or plate stock using electro discharge machining $(\mathrm{EDM})$. Approximately 5 mils $(0.127 \mathrm{~mm})$ of material was conventionally machined from all sides of the coupons to remove the recast layer left by the EDM process. From this point the coupons were sanded with 220 grit silicon carbide paper, washed, dried, and documented. Alloy compositions for the heats of material used are in Table 3-8.

Table 3-8 Heat Chemistries for Coupon Alloys

\begin{tabular}{|c|c|c|c|c|}
\hline \multirow[b]{2}{*}{ Element } & \multicolumn{4}{|c|}{ Alloys; (wt\% in alloy) } \\
\hline & $\begin{array}{l}\text { Inconel } 693 \\
\text { Heat\#D57277 }\end{array}$ & Inconel 693* & $\begin{array}{l}\text { Inconel MA 758 } \\
\text { Heat\# DT2435HP }\end{array}$ & SRTC Alloy \\
\hline $\mathrm{Mn}$ & 0.098 & 0.10 & 0.001 & \\
\hline $\mathrm{Fe}$ & 5.296 & 5.14 & 0.0705 & Proprietary \\
\hline $\mathrm{Si}$ & 0.103 & 0.12 & 0.077 & \\
\hline $\mathrm{Cr}$ & 30.13 & 30.34 & 30.49 & \\
\hline Co & & 0.61 & & \\
\hline Mo & & 0.06 & & \\
\hline $\mathrm{P}$ & & 0.004 & & \\
\hline Wo & & $<0.01$ & & \\
\hline $\mathrm{Ni}$ & Bal & 59.52 & Bal & \\
\hline $\mathrm{Al}$ & 3.25 & 3.26 & 0.344 & \\
\hline $\mathrm{Ti}$ & 0.1402 & 0.20 & 0.4575 & \\
\hline $\mathrm{V}$ & & 0.01 & & \\
\hline B & & $<0.001$ & & \\
\hline $\mathrm{Nb}$ & & 0.54 & & \\
\hline Ta & & $<0.01$ & & \\
\hline $\mathrm{Cu}$ & & $<0.01$ & & \\
\hline $\mathrm{Zr}$ & & 0.04 & & \\
\hline $\mathrm{Mg}$ & & 0.009 & & \\
\hline $\mathrm{Ce}$ & & $<0.01$ & & \\
\hline $\mathrm{La}$ & & $<0.01$ & & \\
\hline $\mathrm{Ca}$ & & $<0.01$ & & \\
\hline $\mathrm{Y}$ & 0.0003 & & 0.4554 & \\
\hline $\mathrm{C}$ & 0.007 & & 0.053 & \\
\hline $\mathrm{N}$ & & & 0.1352 & \\
\hline $\mathrm{O}$ & & & 0.4233 & \\
\hline
\end{tabular}

*I-693 used for Pt-coated samples. Note: Blank spaces denote no analysis performed/provided by manufacturer for those elements 
A set of the Inconel 693 coupons was sent to INTA Technologies in Santa Clara, California where they were first coated with a strike of nickel and then electroplated with between 10 to $15 \mu \mathrm{m}$ of platinum. The nickel flash coat was on the order of less than a micron thick and was applied to provide a uniform, predictable surface for coating. Following electroplating, the coupons were heat-treated for ten minutes at $750^{\circ} \mathrm{C}$ in hydrogen to promote diffusion of the coatings.

The last two materials tested were coatings on Inconel 690. Sulzer Metco, Inc coated $1 / 8^{\text {th }}$ inch rods with approximately 130 to $200 \mu \mathrm{m}$ of Amdry 964 and between 100 to $150 \mu \mathrm{m}$ of AE 7855. The coatings were sprayed on using a high velocity oxygen fuel (HVOF) sprayer. Table 3-9 contains material certification data for the lots of material used. Figures 3-6, 3-7, and 3-8 are the molten glass experiment coupons prior to testing. Figures 3-9 through 3-13 are the long-term vapor space experiment coupons prior to testing. Table 3-10 and Table 3-11 contain dimensions of the coupons prior to testing.

Table 3-9 Material Certifications for Amdry 964 and AE 7855 Coatings

\begin{tabular}{|l|l|c|c|}
\hline & & \multicolumn{2}{|c|}{ Coatings (wt\% in coatings) } \\
\hline Element & Analytical Method & $\begin{array}{l}\text { Amdry 964 } \\
\text { Lot No. 291309 }\end{array}$ & $\begin{array}{l}\text { AE 7855 } \\
\text { Lot No. 291305 }\end{array}$ \\
\hline $\mathrm{Al}$ & ICP & 11.26 & 11 \\
\hline $\mathrm{B}$ & & & 0.29 \\
\hline $\mathrm{C}$ & Combustion & 0.01 & 0.02 \\
\hline $\mathrm{Co}$ & & & 19 \\
\hline $\mathrm{Cr}$ & ICP & 31.00 & 28 \\
\hline $\mathrm{Ni}$ & Balance & 56.92 & 29 \\
\hline $\mathrm{Re}$ & & & 3 \\
\hline $\mathrm{Si}$ & & & 0.03 \\
\hline $\mathrm{S}$ & Combustion & $<0.010$ & 5 \\
\hline $\mathrm{Ta}$ & & & 4 \\
\hline $\mathrm{Y}$ & ICP & 0.56 & $<0.03$ \\
\hline $\mathrm{T} . \mathrm{A} . \mathrm{O}$. & ICP & $<0.20$ & \\
\hline $\mathrm{H}_{2}$ & LECO & 0.003 & 0.03 \\
\hline $\mathrm{O}_{2}$ & LECO & 0.02 & 0.00 \\
\hline $\mathrm{N}_{2}$ & LECO & 0.03 & 5 \\
\hline
\end{tabular}

Blank spaces denote no analysis performed or provided by manufacturer for those elements 
WSRC-TR-2002-00588, REV. 0

SRT-RPP-2002-00283. REV. 0

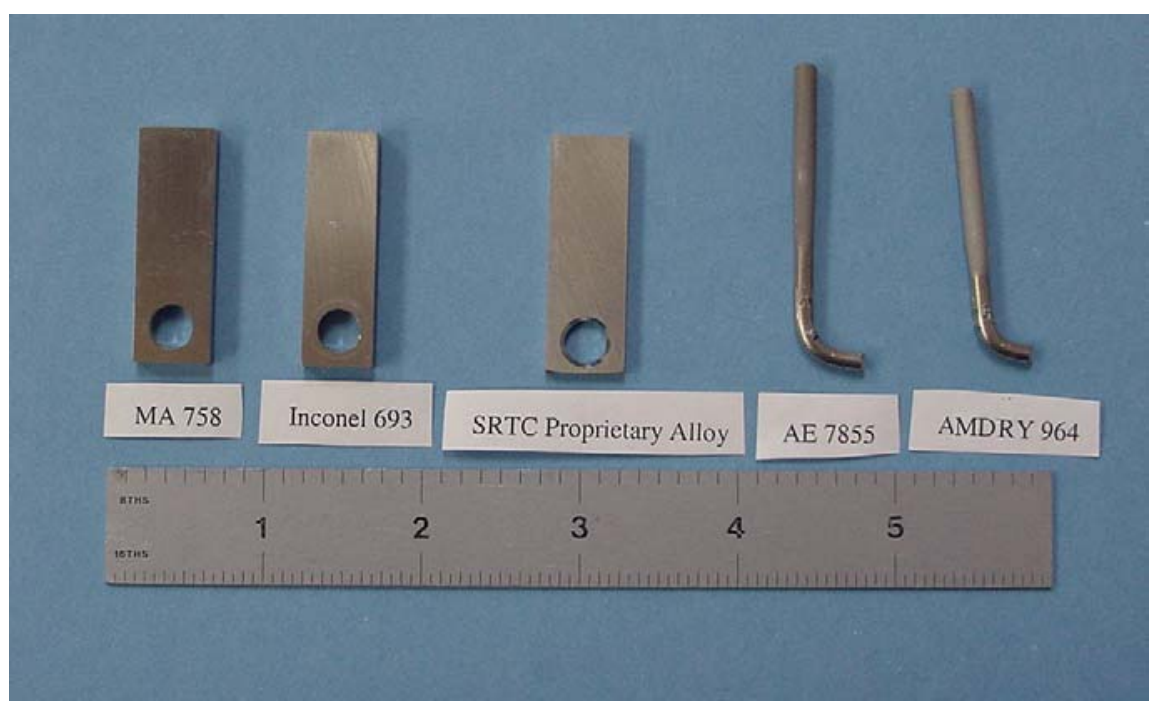

Figure 3-6 Molten Glass Experiment Coupons Prior to Testing

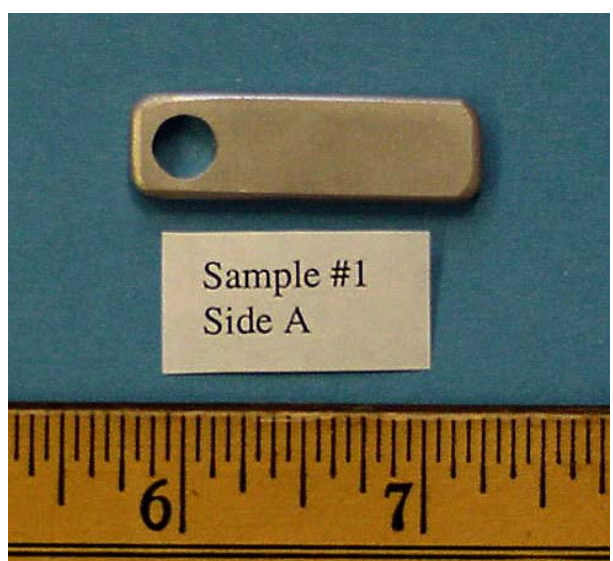

Figure 3-7 Pt-Coated I-693 Coupon for Molten Glass Testing, Prior to Testing

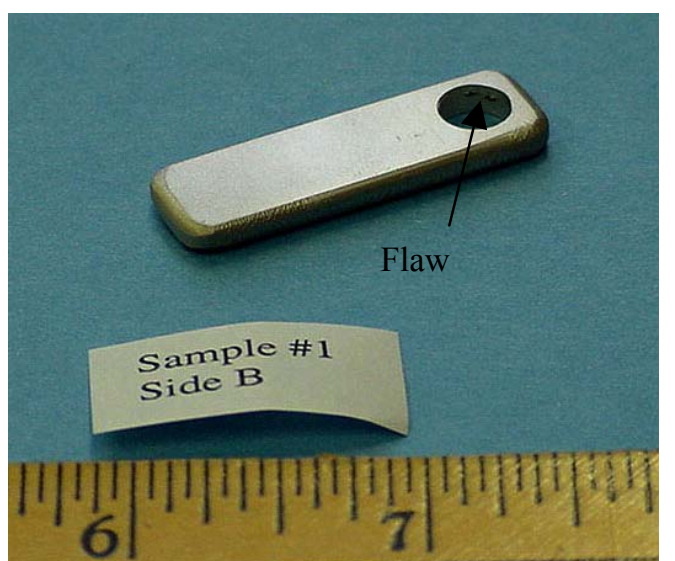

Figure 3-8 Pt-Coated Coupon Showing Flaw inside of Attachment Point 
WSRC-TR-2002-00588, REV. 0

SRT-RPP-2002-00283. REV. 0

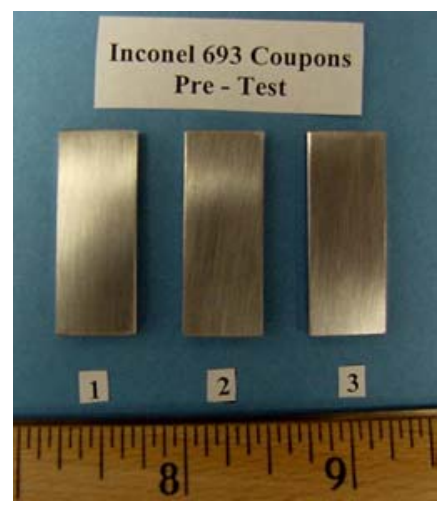

Figure 3-9 I-693 Coupons for Vapor Testing, Prior to Testing

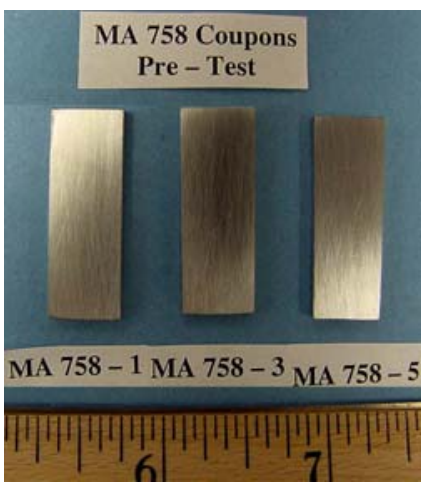

Figure 3-10 MA 758 Coupons for Vapor Testing, Prior to Testing

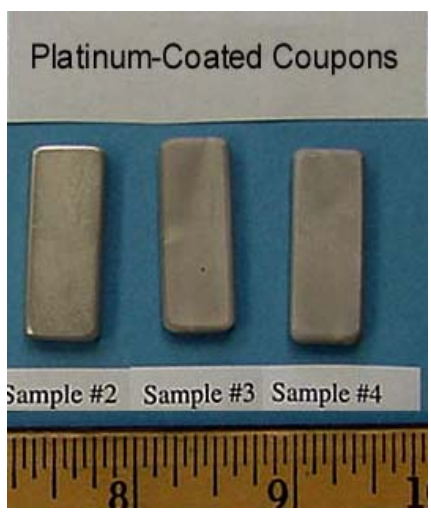

Figure 3-11 Pt-Coated I-693 Coupons for Vapor Testing, Prior to Testing

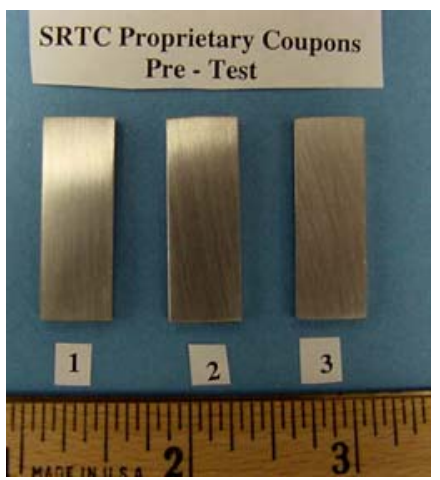

Figure 3-12 SRTC Coupons for Vapor Testing, Prior to Testing

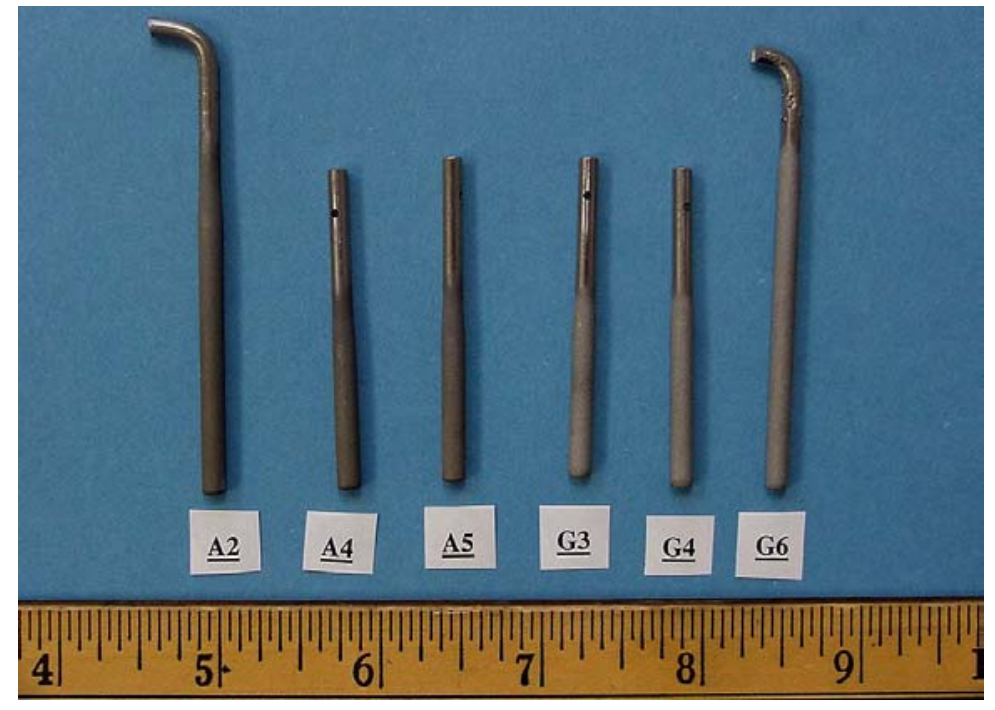

Figure 3-13 AE 7855 (A) and Amdry (G) Coupons for Vapor Testing, Prior to Testing 
WSRC-TR-2002-00588, REV. 0

SRT-RPP-2002-00283. REV. 0

Table 3-10 Initial Coupon Dimensions (cm) for Molten Glass Experiment

\begin{tabular}{|c|c|c|c|c|c|c|}
\hline Top Thic & $\begin{array}{l}\text { Inconel 693 } \\
0.4587\end{array}$ & $\begin{array}{l}\text { MA758 } \\
0.4232\end{array}$ & $\begin{array}{l}\text { ALLVAC } \\
0.2685\end{array}$ & $\begin{array}{l}\text { AE7855 Coated } \\
\text { Inco 690 Rod } \\
0.3757\end{array}$ & $\begin{array}{l}\text { Amdry Coated } \\
\text { Inco 690 Rod } \\
0.3650\end{array}$ & \begin{tabular}{|l} 
Ptcoated \\
Inco 693 \\
0.3205
\end{tabular} \\
\hline Middle Thick. & 0.4605 & 0.4247 & 0.2649 & 0.3749 & 0.3647 & 0.3205 \\
\hline Bottom Thick. & 0.4610 & 0.4267 & 0.2649 & 0.3759 & 0.3637 & 0.3205 \\
\hline Bottom Width & 1.1166 & 1.2454 & 1.2431 & 0.3764 & 0.3653 & Not mea \\
\hline
\end{tabular}

Table 3-11 Initial Coupon Dimensions (cm) for Vapor Space Experiment

\begin{tabular}{|l|l|l|l|l|}
\hline Coupon & Length(avg) & Width(avg)* & Thickness (avg)* & Surface Area(in $\left.{ }^{2}\right)$ \\
\hline I-693 & & & & \\
\hline $400^{\circ} \mathrm{C}$ & 3.160 & 1.217 & 0.320 & 10.490 \\
\hline $600^{\circ} \mathrm{C}$ & 3.157 & 1.217 & 0.318 & 10.458 \\
\hline $900^{\circ} \mathrm{C}$ & 3.157 & 1.217 & 0.320 & 10.484 \\
\hline Pt-Coated I-693 & & & & \\
\hline $400^{\circ} \mathrm{C}$ & 3.145 & 1.191 & 0.358 & 10.581 \\
\hline $600^{\circ} \mathrm{C}$ & 3.142 & 1.181 & 0.363 & 10.548 \\
\hline $900^{\circ} \mathrm{C}$ & 3.127 & 1.184 & 0.363 & 10.529 \\
\hline $\mathrm{MA} 758$ & & & & \\
\hline $400^{\circ} \mathrm{C}$ & 3.091 & 1.077 & 0.323 & 9.329 \\
\hline $600^{\circ} \mathrm{C}$ & 3.101 & 1.092 & 0.320 & 9.452 \\
\hline $900^{\circ} \mathrm{C}$ & 3.165 & 1.092 & 0.318 & 9.626 \\
\hline $\mathrm{SRTC}$ Alloy & & & & \\
\hline $400^{\circ} \mathrm{C}$ & 3.142 & 1.105 & 0.328 & 9.723 \\
\hline $600^{\circ} \mathrm{C}$ & 3.162 & 1.105 & 0.328 & 9.787 \\
\hline $900^{\circ} \mathrm{C}$ & 3.139 & 1.105 & 0.328 & 9.716 \\
\hline & Coated Length & Coated Dia. & & Total Surface Area \\
\hline $\mathrm{AE} 7855$ Coated I-690 & & & & \\
\hline $400^{\circ} \mathrm{C}$ & 5.1 & 0.4 & & 8.3 \\
\hline $600^{\circ} \mathrm{C}$ & 2.5 & 0.4 & & 5.5 \\
\hline $900^{\circ} \mathrm{C}$ & 2.5 & 0.4 & & 5.5 \\
\hline Amdry Coated I-690 & & & & \\
\hline $400^{\circ} \mathrm{C}$ & 5.1 & 0.4 & & 5.4 \\
\hline $600^{\circ} \mathrm{C}$ & 2.5 & 0.4 & & 5.5 \\
\hline $900^{\circ} \mathrm{C}$ & 2.5 & 0.4 & & \\
\hline & & & \\
\hline
\end{tabular}

- $\quad$ Average of three measurements. 
WSRC-TR-2002-00588, REV. 0

SRT-RPP-2002-00283. REV. 0

\subsubsection{Experimental Setup and Method}

\subsubsection{Molten Glass Experimental Setup and Method}

The test coupons attached to a rack and placed in a test crucible are shown in Figure 3-14 and Figure 3-15. Table 3-10 contains initial dimensions of each coupon. The glass supplied by VSL was finely ground, weighed into precise charges and placed into mullite crucibles. The glass charges were replaced on a daily basis, except on weekends, in order to maximize exposure to corrosive species, i.e. $\mathrm{Cl}$ and $\mathrm{SO}_{4}$. To minimize thermal shock to the coupons, the coupon rack remained in the furnace when the crucibles were replaced. This was accomplished by lifting the rack with a rod that was inserted through the top of the furnace and secured with a clamp until the crucible was replaced. After the ground glass melted the coupons were lowered into crucible and maintained at $1150{ }^{\circ} \mathrm{C}$. A lid was not used on top the crucible thus the coupons and glass remained open to the furnace environment at all times.

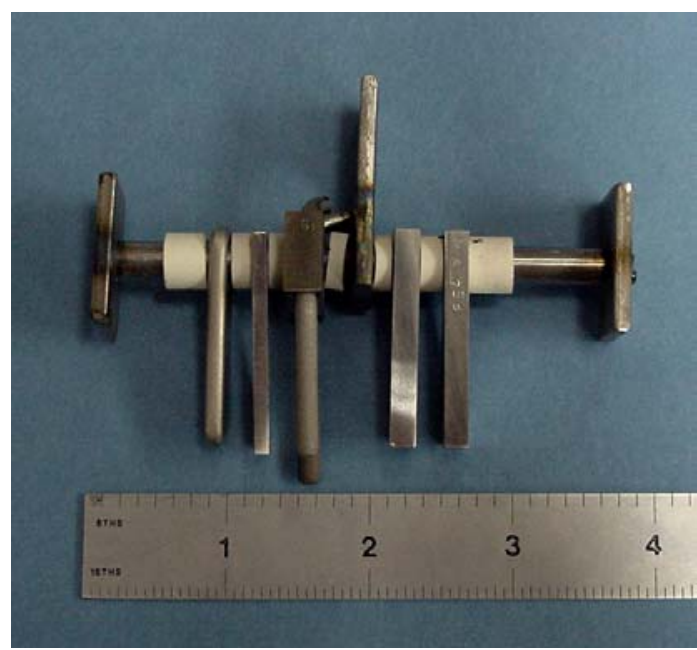

Figure 3-14 Molten Glass Coupon Rack Prior to Testing,

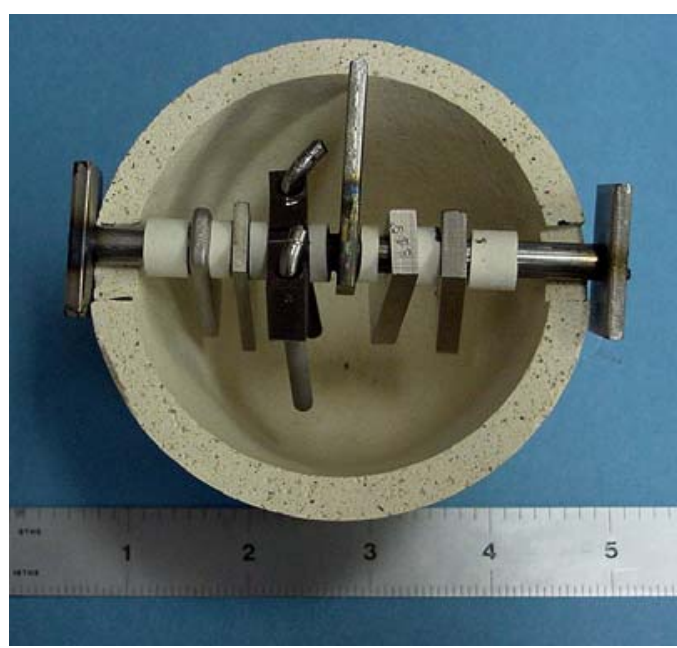

Figure 3-15 Molten Glass Coupon Rack and Crucible, Prior to Testing

\subsubsection{Vapor Space Experimental Setup and Method}

In the vapor space corrosion simulation, a quartz chimney was inserted through the top of a muffle furnace containing a crucible of simulant LAW melter feed. A quartz lid was then placed flush on top of the crucible and was connected to the quartz chimney above with a sliding tube-in-tube joint. Three sets of test material coupons were positioned in the chimney in sections that reached $900^{\circ} \mathrm{C}, 600^{\circ} \mathrm{C}$, and $400^{\circ} \mathrm{C}$ during muffle furnace operation. To maintain the $900^{\circ} \mathrm{C}$ region, a cylindrical ceramic heater was set directly on top of the muffle furnace, surrounding the first $15 \mathrm{~cm}$ of the chimney extending out of the furnace. During operation, thermocouples were used to continuously monitor the temperature zones. See Figure 3-16 and Figure 3-17. 
WSRC-TR-2002-00588, REV. 0

SRT-RPP-2002-00283. REV. 0

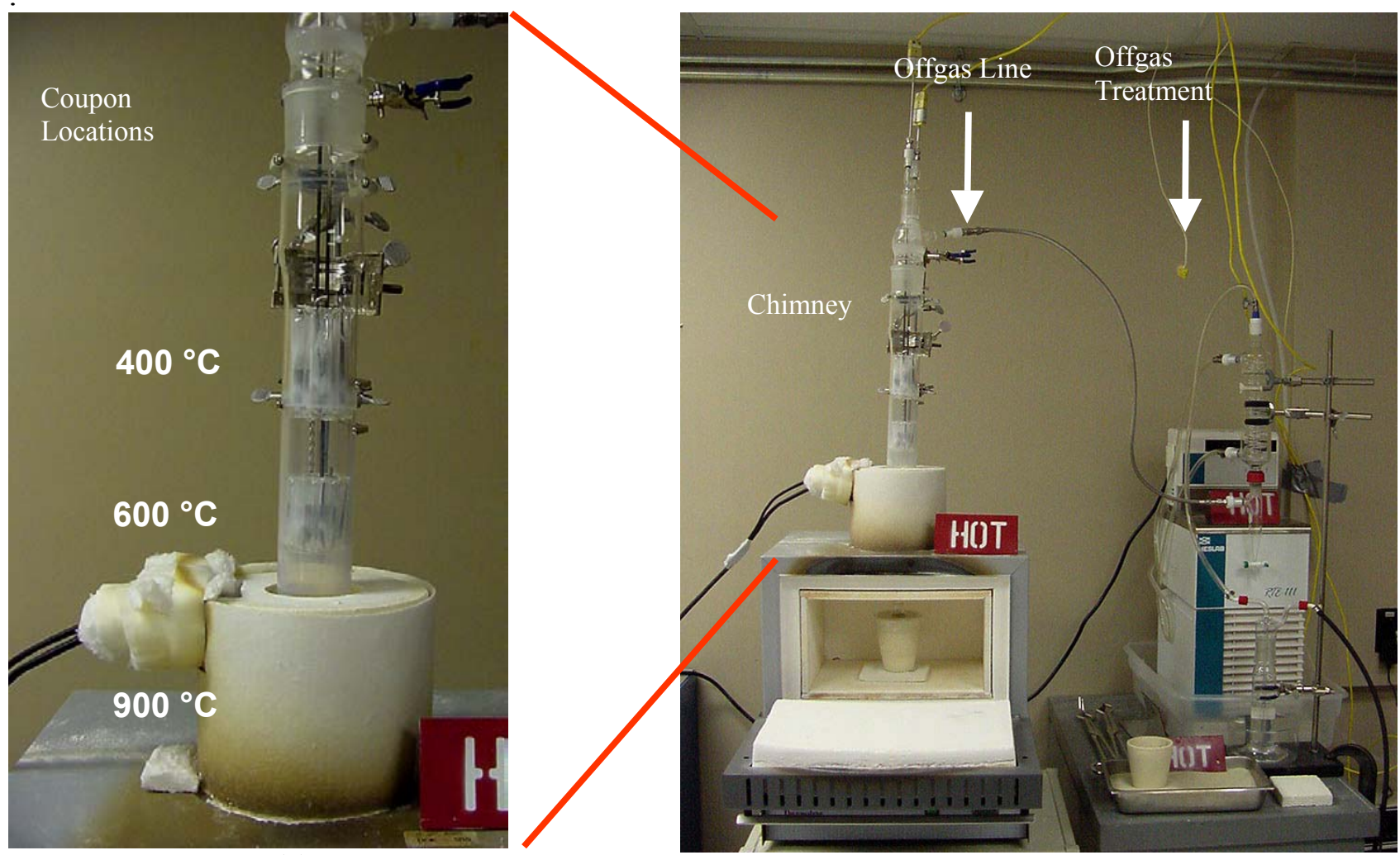

(a)

(b)

Figure 3-16 Long-Term Vapor Space Test Apparatus a) Closeup of three coupon positions and b) Overall test setup 
WSRC-TR-2002-00588, REV. 0

SRT-RPP-2002-00283. REV. 0

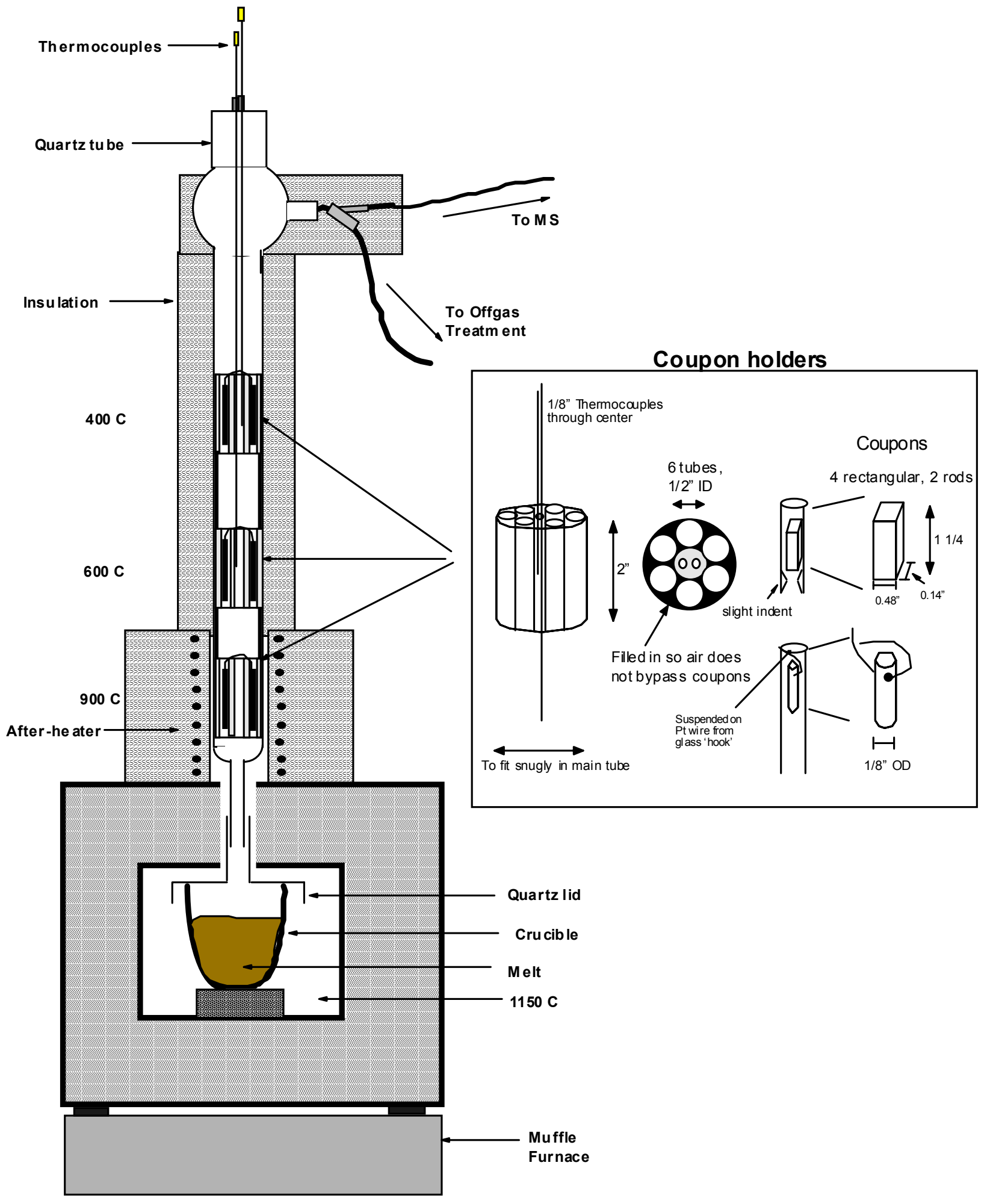

Figure 3-17 Schematic of Long-Term Vapor Space Apparatus 
WSRC-TR-2002-00588, REV. 0

SRT-RPP-2002-00283. REV. 0

Each set of test coupons was placed in a quartz holder. The six coupons per set were positioned evenly around the vertical axis of the chimney. See Figure 3-18. Air was pulled through the assembly from the crucible-lid interface by a venturi positioned downstream of the chimney. After leaving the chimney, the offgas passed through a condenser, a bubbler of sodium hydroxide solution, and a dry ice cold trap before exiting through the venturi.
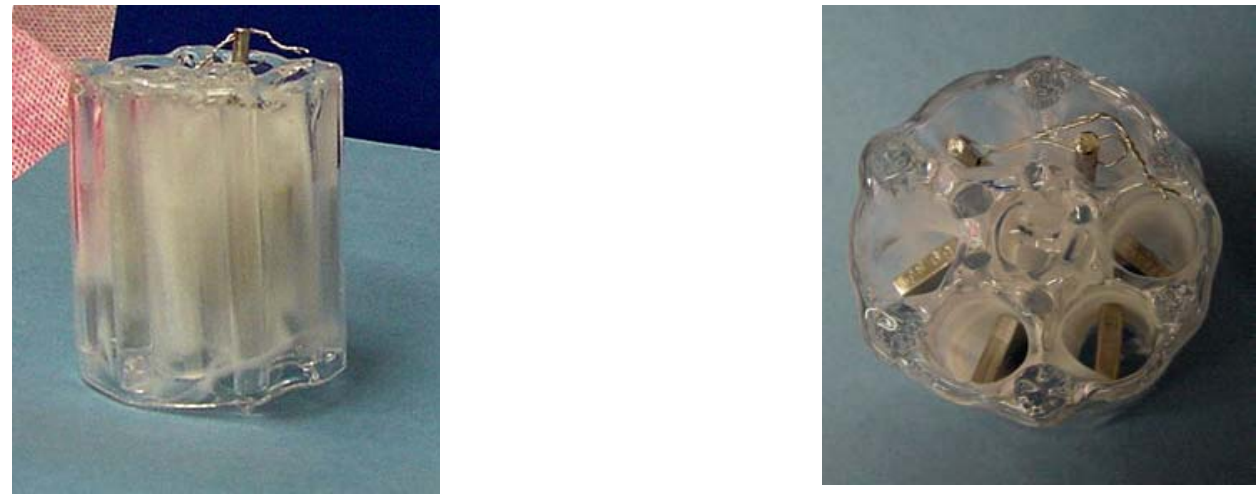

Figure 3-18 Coupon Holder for the $600^{\circ} \mathrm{C}$ Zone, Before Testing

Prior to beginning the experiment, LAW melter feed was batched to a series of $250 \mathrm{ml}$ mullite crucibles in the amount of fifty-five milliliters per batch. After batching, the feed was dried at $105^{\circ} \mathrm{C}$ for a minimum of three days before use in the vapor space corrosion experiment. Plant air was supplied to the venturi at $80 \mathrm{psi}$ and the flowrate through the chimney was adjusted to approximately $130-150 \mathrm{ml} / \mathrm{min}$. The muffle furnace was heated to $1150^{\circ} \mathrm{C}$ and the first crucible placed in the furnace, with the quartz lid lowered on top of it. The crucible was initially replaced once daily. The frequency of changeout was increased to twice daily after the first eight crucibles in order to maximize the amount of offgas passing over the coupons. Crucibles were changed out during the business week, with the last of the week left in over the weekend.

\subsubsection{Preparation of coupons for analysis after testing}

After completion of the experiments, the coupons were weighed and photographed, and the thickness of the coupons (diameter for AE 7855 and Amdry 964 coated rods) were measured. Each coupon from the long-term vapor space study was submerged in $15 \mathrm{ml}$ of boiling deionized water to leach off soluble salts (the AE 7855 and Amdry coated rods were submerged in $26 \mathrm{ml}$ of water). The solutions were removed from the heat and left to stand for 24 hours, with the resulting solutions sent for ICP and IC analyses for quantification of anions and cations. The coupons were re-weighed and re-measured after washing.

A vertical cut was then made through the thickness of the rectangular coupons, parallel to the long axis using an abrasive saw. See Figure 3-19. The resulting cross sections were 
mounted in resin and ground and polished to a one-micron finish. The cross sections were then analyzed with the SEM and Energy Dispersive Spectrometry (EDS).

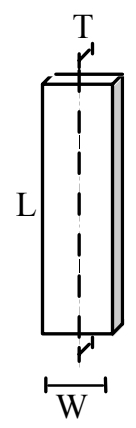

Figure 3-19 Cross Section Cut for Coupons

\subsection{RESULTS A ND DISCUSSION}

\subsubsection{Molten Glas s Experiment}

The coupons were removed after 53 days of exposure. Figure 3-20 shows the condition of the coupons after test completion. Initial observations indicated that both the rods coated with Amdry 964 and AE 7855 had spalled and therefore, no further evaluations of these coupons were performed.

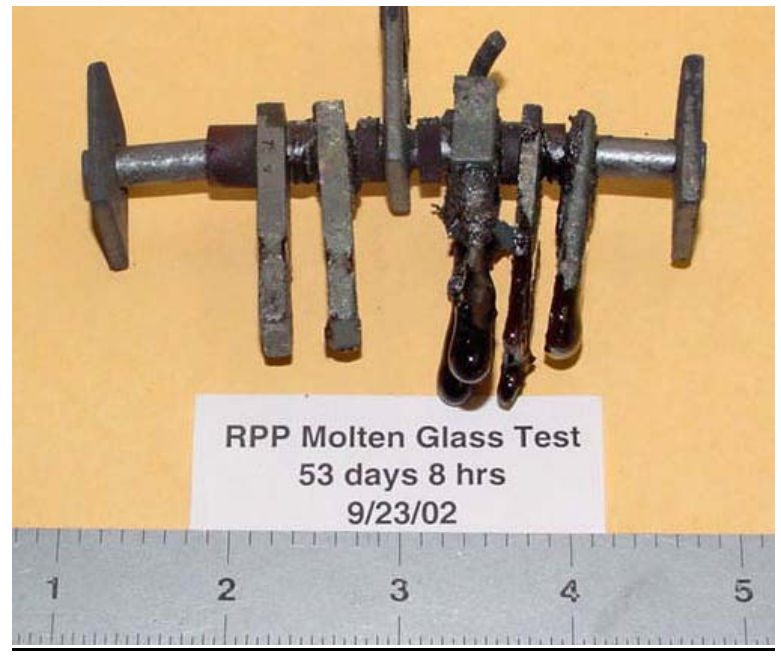

Figure 3-20 Molten Glass Testing Coupons After Completion of Experiment

SEM photographs were taken in representative areas showing regions of normal attack and areas considered to be worst case. The data are qualitative and are not meant to determine actual corrosion rates for engineering systems. A representative series of SEM photographs are shown in Figure 3-21. Areas deemed to be normal and worst case were then selected for further evaluation at higher magnification. A series of SEM photographs and representative EDS spectra are shown for each alloy in Appendix C. 
WSRC-TR-2002-00588, REV. 0

SRT-RPP-2002-00283. REV. 0
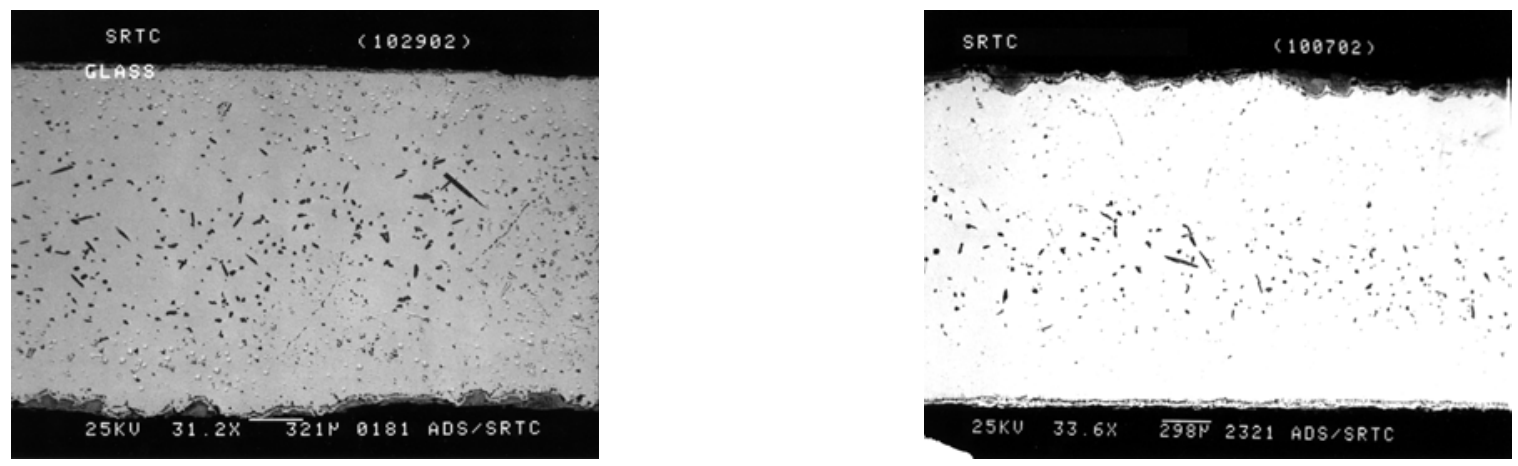

SRTC Alloy (Glass)
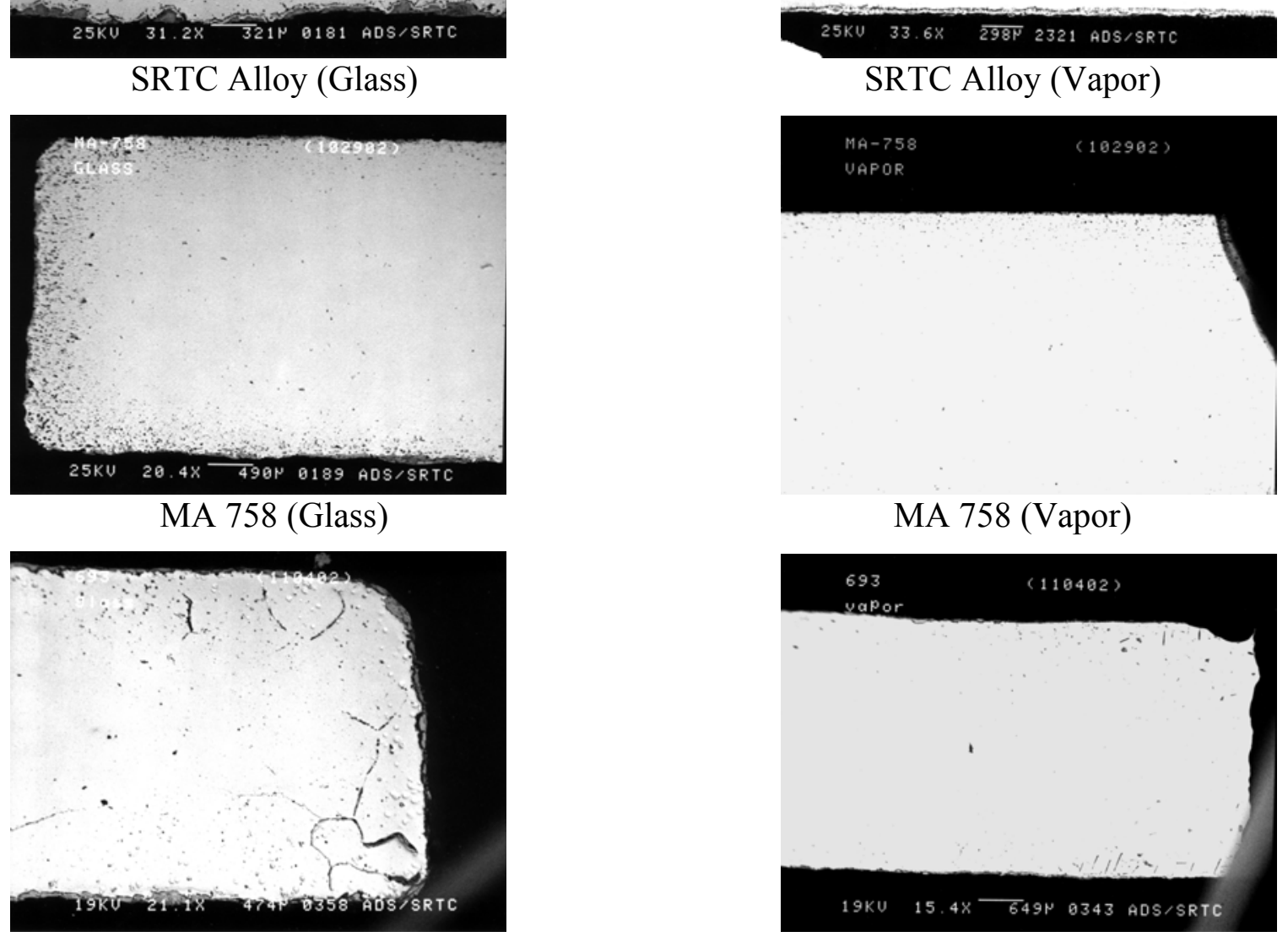

I-693 (Glass)

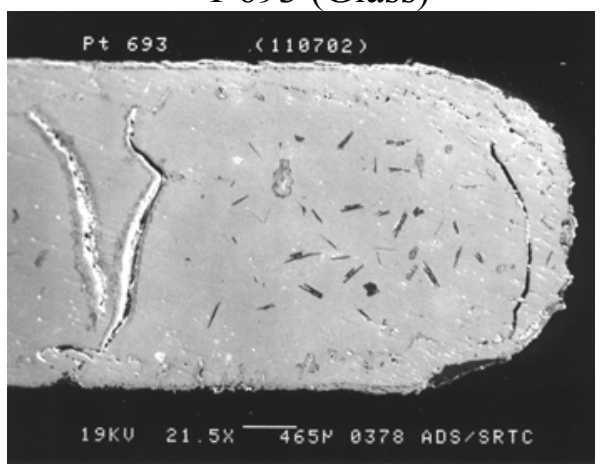

I-693 (Vapor)

I-693 Pt Coated (Glass)

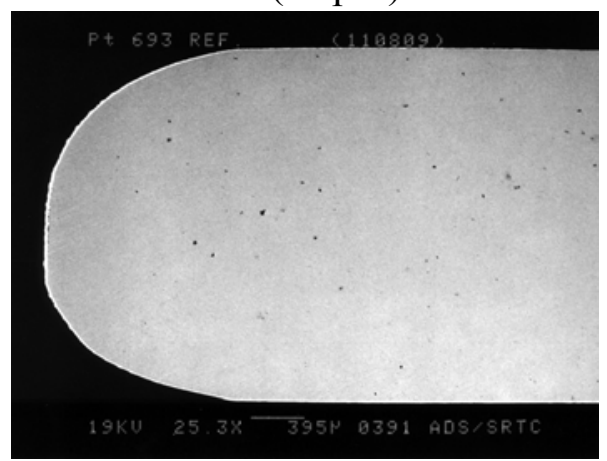

As Received I-693 Pt Coated (Vapor)

Figure 3-21 SEM Photographs Showing Condition of Coupons After Molten Glass Exposure. 
EDS results indicate that chromium depletion was evident in the near surface region of all the coupons. This is evident in the MA 758 glass contact coupon EDS spectra locations 2, 3, and Center shown in Appendix C. An alumina layer was found beneath the outer $\mathrm{Cr}_{2} \mathrm{O}_{3}$ layer in all the coupons and can be seen in the Inconel 693 glass contact coupon locations 9 and 10. This is expected since all the coupons contain aluminum additions. The large particles located in the center of Inconel $693 \mathrm{Pt}$ coated and SRTC glass contact coupons consisted mainly of aluminum. Similar particles have been seen in high temperature oxidation studies performed at SRTC with similar alloys but further investigation of their composition or effect on mechanical properties has not been undertaken. All of the coupons experienced varying degrees of internal attack including internal void formation, intergranular attack (IGA) and chromium depletion. No evidence of chlorine or sulfur was found on the grain boundaries with the limited characterization performed.

Significant intergranular attack of the platinum-coated Inconel 693 coupon was observed. A SEM photograph showing several intergranular cracks is shown in Appendix A, Figure C-7, Photo A. The IGA was significantly deeper than observed in the uncoated I-693 coupon and appeared to originate from a large pit on the surface of the coupon. Both the crack and pit contained chromium oxide. The platinum coating was discontinuous in the region around the pit and was observed on the outermost surface on top of the chromium oxide layer. It is assumed that the chromium oxide formed at the nickel strike/Inconel interface but this was not confirmed during this evaluation; the nickel strike was less than a micron in thickness according to the plating vendor. Transport of oxygen to the substrate may have been accelerated if the as-received electroplated platinum coating contained defects such as pores or scratches. Oxygen could also reach the substrate by diffusion. Although the platinum would be ductile at $1150{ }^{\circ} \mathrm{C}$, it may have fractured because it could not accommodate the volume expansion associated with the chromium oxide formation. Fissures in the protective coating would then allow localized corrosion of the substrate, i.e., crevice, pitting or IGA. Corrosive attack may have been further accelerated by a galvanic effect between the platinum and Inconel substrate. Residual contamination from the plating bath may also have contributed to the observed IGA; however, none was detected by the EDS analysis. A more extensive analysis of the coupon and further testing would be needed to determine the reason for the extensive IGA in the plated I-693 coupon.

Total degradation, which is the sum of material loss (total material loss/2) and depth of internal attack, was used to rank the materials. The coupons were carefully sectioned longitudinally and mounted to maintain a cross sectional surface orthogonal to the sides. A measuring microscope was then used to measure the total material loss in the glass, glass/air interface, and vapor regions. Both optical microscopy and SEM analyses were performed to determine internal depth of attack. Initially the metallographic photographs were used for these measurements, however, upon completion of the SEM investigation, the SEM photographs were used since they had better resolution. Table 3-12 contains the depth of internal attack and final thickness of each coupon. No measurements were taken of the platinum-coated coupon because the internal cracking was so severe. Total 
WSRC-TR-2002-00588, REV. 0

SRT-RPP-2002-00283. REV. 0

degradation from one side of the coupon and the relative ranking of the materials based on this calculation is shown in Table 3-13. The data for total degradation indicates that the performance of the SRTC alloy was superior to the MA 758 and Inconel 693 in both the molten glass and vapor regions.

Table 3-12 Final Thickness and Depth of Internal Attack Following Molten Glass Exposure.

\begin{tabular}{|l|c|c|c|c|c|c|c|c|c|}
\hline \multirow{3}{*}{ Material } & \multicolumn{5}{|c|}{ Internal Depth of Attack $(\mu \mathrm{m})$} & \multicolumn{3}{|c|}{ Final Coupon Thickness $(\mu \mathrm{m})$} \\
\cline { 2 - 8 } & \multicolumn{4}{|c|}{ Glass } & \multicolumn{3}{|c|}{ Vapor } & Interface & Glass \\
\cline { 2 - 10 } & Max & Min & Avg & Max & Min & Avg & & & \\
\hline SRTC & 233 & 41 & 137 & 77 & 69 & 73 & 2447 & 2295 & 2422 \\
\hline MA 758 & 443 & 429 & 436 & 372 & 101 & 236 & 4238 & 3913 & 4165 \\
\hline I-693 & 766 & 193 & 480 & 326 & 83 & 204 & 4287 & 3852 & 4086 \\
\hline
\end{tabular}

Table 3-13 Total Degradation Using Maximum and Average Depth of Attack.

\begin{tabular}{|c|c|c|c|c|c|c|c|c|c|c|}
\hline \multirow{3}{*}{ Material } & \multicolumn{4}{|c|}{ Internal Depth of Attack $(\mu \mathrm{m})$} & \multicolumn{2}{|c|}{$\begin{array}{l}\text { Total Material } \\
\text { Loss }(\mu \mathrm{m})^{*}\end{array}$} & \multicolumn{2}{|c|}{$\begin{array}{c}\text { Total Degradation } \\
(\mu \mathrm{m})^{* *}\end{array}$} & \multicolumn{2}{|c|}{$\begin{array}{c}\text { Total } \\
\text { Degradation } \\
(\mu \mathrm{m}) * * *\end{array}$} \\
\hline & \multicolumn{2}{|c|}{ Glass } & \multicolumn{2}{|c|}{ Vapor } & \multirow[t]{2}{*}{ Glass } & \multirow[t]{2}{*}{ Vapor } & \multirow[t]{2}{*}{ Glass } & \multirow[t]{2}{*}{ Vapor } & \multirow[t]{2}{*}{ Glass } & \multirow[t]{2}{*}{ Vapor } \\
\hline & Max & Avg & Max & Avg & & & & & & \\
\hline SRTC & 233 & 137 & 77 & 73 & 241 & 216 & 353 & 185 & 257 & 181 \\
\hline MA 758 & 443 & 436 & 372 & 236 & 86 & 13 & 486 & 378 & 479 & 243 \\
\hline $\mathrm{I}-693$ & 766 & 480 & 326 & 204 & 516 & 315 & 1024 & 484 & 737 & 362 \\
\hline
\end{tabular}

* Material loss from both sides of the coupon

** Total degradation using maximum internal depth of attack

*** Total degradation using average internal depth of attack

\subsubsection{Long-Term V apor Space Experiment}

\subsubsection{Operationa I Results and Observations}

Seventy-four $55 \mathrm{ml}$ batches of feed were vitrified in the furnace, equating to 4,070 $\mathrm{ml}$ total feed and 3,500 grams of glass produced. The temperature at the coupon set in the $900^{\circ} \mathrm{C}$ zone of the offgas chimney varied plus or minus five degrees. The $600^{\circ} \mathrm{C}$ and $400^{\circ} \mathrm{C}$ zones that contained the other two sets of coupons maintained a plus or minus $35^{\circ} \mathrm{C}$ variance for the first 40 crucibles. The variance was decreased to plus or minus $10^{\circ} \mathrm{C}$ for the last 34 crucibles. The furnace was shut down twice during the experiment, once for a power outage and once for replacement of quartz components. Flow through the venturi was maintained between 130 and $145 \mathrm{ml} / \mathrm{min}$ following initial adjustments in the first day. Table 3-14 summarizes operational results. 
WSRC-TR-2002-00588, REV. 0

SRT-RPP-2002-00283. REV. 0

Table 3-14 Operational Summary of Vapor Space Corrosion Experiment

\begin{tabular}{|l|l|}
\hline Parameter & Result \\
\hline Number of 55 ml crucible batches vitrified & 74 \\
\hline Amount of simulant feed vitrified & $4,070 \mathrm{ml}$ \\
\hline Amount of glass produced & $3,500 \mathrm{~g}$ \\
\hline Total elapsed time of experiment & 85 days \\
\hline Total time of experiment at LAW operating temperature & 71.6 days \\
\hline
\end{tabular}

Glass yield from simulant feed assumed to be $860 \mathrm{~g} / \mathrm{l}$.

Figures 3-22 through 3-24 are pictures of the coupons after completion of the experiment. The coupons exhibited signs of corrosion in all temperature zones of the offgas line. The AE 7855 coating spalled off from the coupons in the $900^{\circ} \mathrm{C}$ zone. In general, the greatest amount of corrosion was seen on the coupons from the $600^{\circ} \mathrm{C}$ zone, followed by the coupons from the $900^{\circ} \mathrm{C}$ and then the $400^{\circ} \mathrm{C}$ zones. The corrosion was greatest on the bottom end of all the coupons, which was the end facing the offgas flow and also the orientation of the end grains. 
WSRC-TR-2002-00588, REV. 0

SRT-RPP-2002-00283. REV. 0

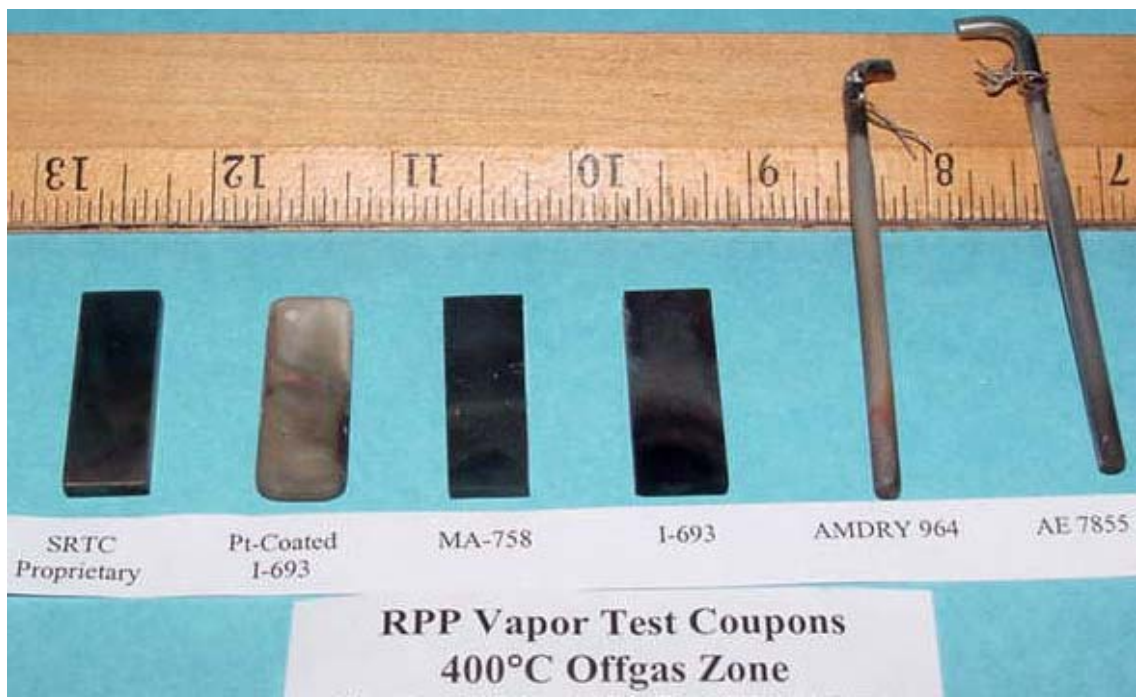

Figure 3-22 Long-Term Vapor Space Coupons from $400^{\circ} \mathrm{C}$ Region, After Testing

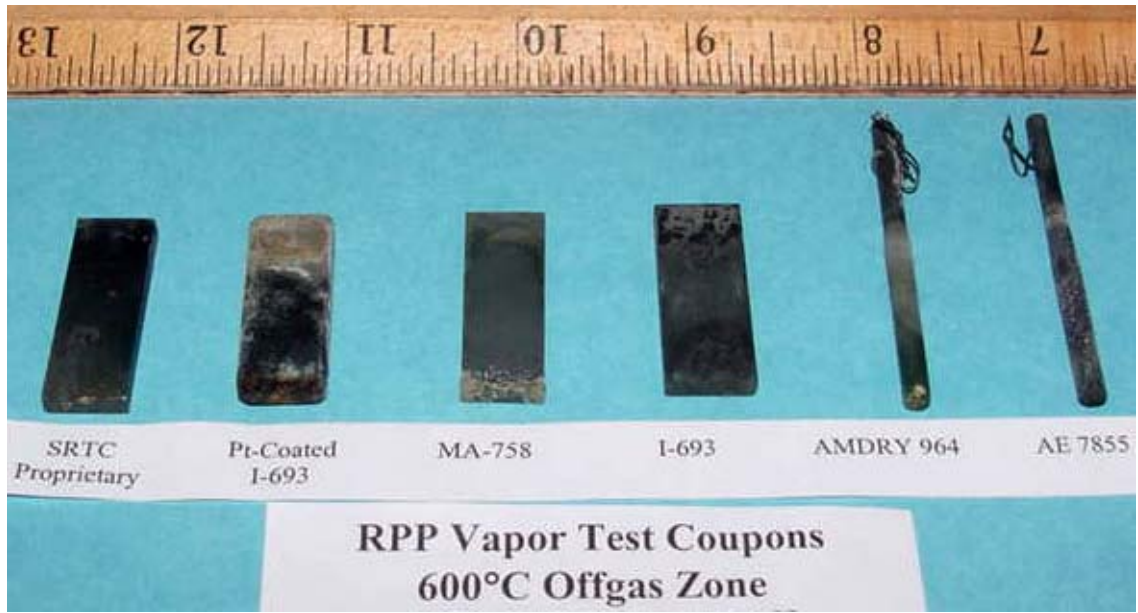

Figure 3-23 Long-Term Vapor Space Coupons from $600^{\circ} \mathrm{C}$ Region, After Testing

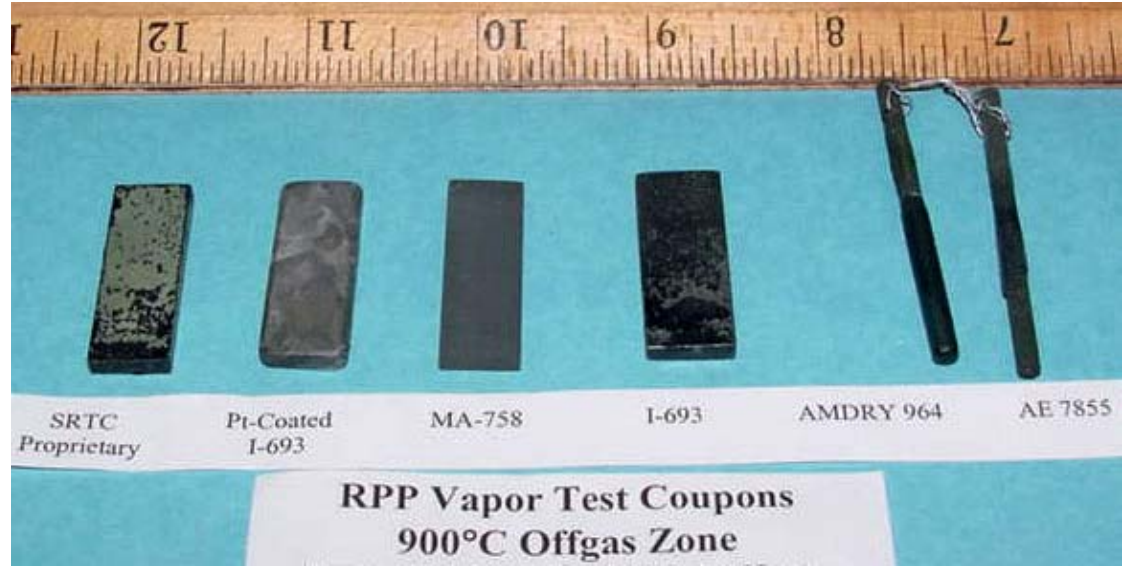

Figure 3-24 Long-Term Vapor Space Coupons from $900^{\circ} \mathrm{C}$ Region, After Testing 
WSRC-TR-2002-00588, REV. 0

SRT-RPP-2002-00283. REV. 0

Table 3-15 contains the difference in weight of each coupon immediately after testing as compared to the initial weight and also the change in weight after attempting to wash deposited salts from the surface of the coupons. Most coupons showed wait gain from salt deposition and most lost weight after coupon washing.

Table 3-15 Coupon Weight Changes for Long-Term Vapor Space Experiment

\begin{tabular}{|l|l|l|}
\hline Coupon & \multicolumn{1}{|c|}{$\begin{array}{c}\text { Post }- \text { Pretest Weight } \\
(\mathrm{g})\end{array}$} & \multicolumn{1}{|c|}{$\begin{array}{c}\text { Washed - Post Weight } \\
(\mathrm{g})\end{array}$} \\
\hline $\mathrm{I}-693$ & \multicolumn{1}{|c|}{$\mathrm{C}$} & -0.0184 \\
\hline $400^{\circ} \mathrm{C}$ & 0.0198 & -0.0074 \\
\hline $600^{\circ} \mathrm{C}$ & 0.0093 & -0.0119 \\
\hline $900^{\circ} \mathrm{C}$ & 0.0137 & \\
\hline Pt-Coated I-693 & & -0.0251 \\
\hline $400^{\circ} \mathrm{C}$ & 0.0255 & -0.0061 \\
\hline $600^{\circ} \mathrm{C}$ & 0.0228 & -0.0041 \\
\hline $900^{\circ} \mathrm{C}$ & 0.0246 & \\
\hline MA 758 & & -0.0033 \\
\hline $400^{\circ} \mathrm{C}$ & 0.0035 & -0.0017 \\
\hline $600^{\circ} \mathrm{C}$ & 0.0047 & 0.0005 \\
\hline $900^{\circ} \mathrm{C}$ & 0.0055 & \\
\hline $\mathrm{SRTC}$ Alloy & & 0.0357 \\
\hline $400^{\circ} \mathrm{C}$ & -0.0349 & -0.0091 \\
\hline $600^{\circ} \mathrm{C}$ & 0.0147 & -0.0052 \\
\hline $900^{\circ} \mathrm{C}$ & -0.0020 & \\
\hline AE 7855 Coated I-690 & & $*$ \\
\hline $400^{\circ} \mathrm{C}$ & 0.0067 & -0.0193 \\
\hline $600^{\circ} \mathrm{C}$ & 0.0495 & -0.0060 \\
\hline $900^{\circ} \mathrm{C}$ & -0.3037 (Coating Spalled) & \\
\hline Amdry Coated I-690 & & $*$ \\
\hline $400^{\circ} \mathrm{C}$ & 0.0038 & -0.0050 \\
\hline $600^{\circ} \mathrm{C}$ & 0.0085 & -0.0238 \\
\hline $900^{\circ} \mathrm{C}$ & 0.0697 & \\
\hline
\end{tabular}

*Uncoated portion partially cut away prior to washing.

\subsubsection{Chemical A nalysis of Materials on Coupon Surfaces}

Sulfur and chlorine were found in varying amounts on the surfaces of the coupons. Without exception, more sulfur and chlorine were found on the coupons from the $600^{\circ} \mathrm{C}$ temperature zone, followed by the $400^{\circ} \mathrm{C}$ zone and then the $900^{\circ} \mathrm{C}$ zone. The $600^{\circ} \mathrm{C}$ coupons correspondingly exhibited the most corrosion. Sulfur was detected on only two coupons from the $900^{\circ} \mathrm{C}$ zone, the Amdry 964 coated coupon and AE 7855 coated coupon. The major cations detected on the coupons were potassium, sodium, cesium, zinc, lead, and barium. Selenium was found on a few coupons, as well. Table 3-16 contains XRF data in the form of relative peak heights from analysis of fixed coupon 
WSRC-TR-2002-00588, REV. 0

SRT-RPP-2002-00283. REV. 0

surface area after completion of the experiment. Table 3-17 and Table 3-18 contain IC and ICP-ES data from analysis of distilled water solutions that the coupons were washed in to remove the soluble salts. The IC and ICP-ES data are on the basis of micrograms per square inch of coupon surface. The two analytical techniques yielded consistent results for sulfur and chlorine concentrations. (Coupon surface areas are listed in Table 3-11.)

Table 3-16 XRF Data for Long-Term Vapor Space Coupons, After Testing

\begin{tabular}{|c|c|c|c|c|c|c|c|c|c|}
\hline & \multicolumn{9}{|c|}{ Counts } \\
\hline $\begin{array}{c}\text { Sample } \\
\text { Identification }\end{array}$ & $\overline{\mathrm{SS}}$ & $\overline{\mathrm{Cl}}$ & $\overline{\mathrm{K}}$ & $\overline{\mathrm{Zn}}$ & $\overline{\mathrm{Pb}}$ & Se & 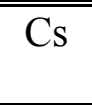 & $\overline{\mathrm{Ba}}$ & $\mathrm{Na}$ \\
\hline I-693 $400^{\circ} \mathrm{C}$ & 3276 & 3170 & 2274 & 400 & 1769 & 4873 & 3521 & 1226 & 6 \\
\hline I-693 $600^{\circ} \mathrm{C}$ & 9280 & 3724 & 11662 & 489 & 1463 & & & & 12 \\
\hline $\mathrm{I}-693900^{\circ} \mathrm{C}$ & & & 5758 & 41561 & 1086 & & & 1387 & $\begin{array}{c}100 \\
5\end{array}$ \\
\hline MA $758400^{\circ} \mathrm{C}$ & & 2899 & 1023 & & 1384 & & & 1925 & 6 \\
\hline MA $758600^{\circ} \mathrm{C}$ & 17982 & 6102 & 13400 & & 1351 & & & 1782 & 3 \\
\hline MA $758900^{\circ} \mathrm{C}$ & & & 1548 & 537 & 832 & & & & 11 \\
\hline SRTC Alloy $400^{\circ} \mathrm{C}$ & & 2124 & 3647 & & 1267 & & 1513 & 1641 & \\
\hline SRTC Alloy $600^{\circ} \mathrm{C}$ & 8176 & 4171 & 32883 & 6332 & 1375 & & 2980 & 2131 & 138 \\
\hline SRTC Alloy $900^{\circ} \mathrm{C}$ & & 1974 & 2688 & 7457 & 996 & & & 1507 & 176 \\
\hline Pt-Coated I-693 $400^{\circ} \mathrm{C}$ & 6018 & 5848 & 4676 & & & & 2360 & 1520 & 6 \\
\hline Pt-Coated I-693 $600^{\circ} \mathrm{C}$ & 6457 & 3191 & 13490 & 1056 & & & 1634 & 1672 & 44 \\
\hline Pt-Coated I-693900 90 & & & 5792 & 26959 & & & & 1960 & 741 \\
\hline AE 7855 Coat $690400^{\circ} \mathrm{C}$ & 8381 & 2072 & & 8456 & & 10241 & & & NA \\
\hline AE 7855 Coat $690600^{\circ} \mathrm{C}$ & 7117 & 2409 & 3381 & 469 & 1365 & & 1010 & 1740 & NA \\
\hline $\mathrm{AE} 7855$ Coat $690900^{\circ} \mathrm{C}^{*}$ & 14844 & 1662 & & 5653 & 165 & 7185 & & & NA \\
\hline Amdry Coat $690400^{\circ} \mathrm{C}$ & 10293 & 2720 & & & 1644 & 6089 & & 2036 & NA \\
\hline Amdry Coat $690600^{\circ} \mathrm{C}$ & 5388 & 2695 & 22636 & 1528 & 1512 & 2773 & 4794 & 1755 & NA \\
\hline Amdry Coat $690900^{\circ} \mathrm{C}$ & 5692 & 2516 & 2105 & & 1502 & 6133 & & 2097 & NA \\
\hline
\end{tabular}

NA- Not Analyzed

Blank space denotes that element was below detection limit.

* Coating spalled off during testing

Kevex ED-XRF Ti target used for S, Cl, K analysis. Zr target used for Zn.

Gd target used for $\mathrm{Pb}, \mathrm{Se}, \mathrm{Cs}$, Ba. Rigaku WD-XRF used for $\mathrm{Na}$. 
WSRC-TR-2002-00588, REV. 0

SRT-RPP-2002-00283. REV. 0

Table 3-17 ICP Leach Data for Long-Term Vapor Space Coupons, After Testing

\begin{tabular}{|c|c|c|c|c|c|}
\hline $\begin{array}{c}\text { Sample } \\
\text { Identification } \\
\end{array}$ & $\begin{array}{r}\mathrm{Ca} \\
\mathrm{\mu g} / \mathrm{in}^{2} \\
\end{array}$ & $\begin{array}{c}\mathrm{Cd} \\
\mu \mathrm{g} / \mathrm{in}^{2} \\
\end{array}$ & $\begin{array}{c}\mathrm{Na} \\
\mu \mathrm{g} / \mathrm{in}^{2} \\
\end{array}$ & $\begin{array}{c}\mathrm{K} \\
\mu \mathrm{g} / \mathrm{in}^{2} \\
\end{array}$ & $\begin{array}{l}\mathrm{SO}_{4}{ }^{*} \\
\mathrm{ug} / \mathrm{in}^{2} \\
\end{array}$ \\
\hline $\mathrm{I}-693400^{\circ} \mathrm{C}$ & & 7.2 & 8.5 & 21 & 23 \\
\hline $\mathrm{I}-693600^{\circ} \mathrm{C}$ & & & 688 & 146 & 1098 \\
\hline $\mathrm{I}-693900^{\circ} \mathrm{C}$ & & & 214 & 27 & \\
\hline $\mathrm{MA} 758400^{\circ} \mathrm{C}$ & & 11 & 8.5 & 22 & 19 \\
\hline MA $758600^{\circ} \mathrm{C}$ & & 0 & 672 & 141 & 1021 \\
\hline MA $758900^{\circ} \mathrm{C}$ & & & 5.8 & & \\
\hline SRTC Allov $400^{\circ} \mathrm{C}$ & 1.4 & 13 & 9.1 & 25 & 19 \\
\hline SRTC Alloy $600^{\circ} \mathrm{C}$ & 1.7 & & 913 & 209 & 1258 \\
\hline SRTC Alloy $900^{\circ} \mathrm{C}$ & & & 82 & 10 & \\
\hline Pt-Coated I-693 $400^{\circ} \mathrm{C}$ & & 18 & 13 & 39 & 97 \\
\hline Pt-Coated I-693 $600^{\circ} \mathrm{C}$ & 7.9 & 0.5 & 652 & 128 & 1049 \\
\hline Pt-Coated I-693 $900^{\circ} \mathrm{C}$ & & & 336 & 40 & \\
\hline $\mathrm{AE} 7855$ Coated I-690 $400^{\circ} \mathrm{C}$ & 5.6 & 53 & & 10 & 864 \\
\hline AE 7855 Coated I- $690600^{\circ} \mathrm{C}$ & 22 & 1.2 & 1277 & 250 & 1720 \\
\hline AE 7855 Coated I-690 $900^{\circ} \mathrm{C}$ & & & 886 & 105 & \\
\hline Amdrv Coated I-690 $400^{\circ} \mathrm{C}$ & & 107 & & 23 & 368 \\
\hline Amdry Coated I-690 $600^{\circ} \mathrm{C}$ & & & 1110 & 358 & 558 \\
\hline Amdry Coated I-690 $900^{\circ} \mathrm{C}$ & 11 & & 2769 & 330 & 27 \\
\hline
\end{tabular}

*Converted from sulfur to sulfate

Blank space denotes that element was below detection limit.

Table 3-18 IC Leach Data for Long-Term Vapor Space Coupons, After Testing

\begin{tabular}{|c|c|c|}
\hline $\begin{array}{c}\text { Sample } \\
\text { Identification } \\
\end{array}$ & $\begin{array}{c}\mathrm{Cl} \\
\mu \mathrm{g} / \mathrm{in}^{2} \\
\end{array}$ & $\begin{array}{r}\mathrm{SO}_{4}^{*} \\
\mu \mathrm{g} / \mathrm{in}^{2} \\
\end{array}$ \\
\hline $\mathrm{I}-693400^{\circ} \mathrm{C}$ & 55 & 18 \\
\hline $\mathrm{I}-693600^{\circ} \mathrm{C}$ & 92 & 1150 \\
\hline $\mathrm{I}-693900^{\circ} \mathrm{C}$ & 18 & \\
\hline $\mathrm{MA} 758400^{\circ} \mathrm{C}$ & 31 & 21 \\
\hline MA $758600^{\circ} \mathrm{C}$ & 197 & 1075 \\
\hline MA $758900^{\circ} \mathrm{C}$ & 21 & \\
\hline SRTC Allov $400^{\circ} \mathrm{C}$ & 40 & 20 \\
\hline SRTC Alloy $600^{\circ} \mathrm{C}$ & 129 & 1250 \\
\hline SRTC Alloy $900^{\circ} \mathrm{C}$ & 20 & \\
\hline Pt-Coated I-693 $400^{\circ} \mathrm{C}$ & 110 & 91 \\
\hline Pt-Coated I-693 $600^{\circ} \mathrm{C}$ & 448 & 1120 \\
\hline Pt-Coated I-693 $900^{\circ} \mathrm{C}$ & 18 & \\
\hline AE 7855 Coated I-690 $400^{\circ} \mathrm{C}$ & 60 & 1450 \\
\hline AE 7855 Coated I-690 $600^{\circ} \mathrm{C}$ & 201 & 3140 \\
\hline AE 7855 Coated I-690 $900^{\circ} \mathrm{C}$ & 40 & \\
\hline Amdrv Coated I-690 $400^{\circ} \mathrm{C}$ & 100 & 597 \\
\hline Amdry Coated I-690 $600^{\circ} \mathrm{C}$ & 119 & 889 \\
\hline Amdry Coated I-690 $900^{\circ} \mathrm{C}$ & 60 & 61 \\
\hline
\end{tabular}

${ }^{*}$ Converted from sulfur to sulfate

Blank space denotes that element was below detection limit. 


\subsubsection{Metallography}

An SEM coupled with EDS was used to analyze polished cross sections of twelve of the coupons from the three temperature regions. Because both the AE 7855 and Amdry 964 coatings spalled off from the coupons in the molten glass testing, they were not considered for further examination in the long-term vapor-space study. SEM micrographs were taken of the bottom portions of each of the coupons as they were arranged in the vertical chimney. The bottom horizontal edges of the coupons were compared in terms of internal depth of attack, appearance, and elemental composition. No measurements were taken for quantitative metal loss because the initial dimensions of the coupons could not be measured with great enough sensitivity.

Table 3-19 contains a qualitative ranking of the coupons for each of the temperature zones. Degradation in the various temperature regions was a result of competing and in some cases synergistic corrosion mechanisms which include corrosion due to $\mathrm{HCl}$ and chlorine gases, chlorination, sulfidation, and oxidation. The qualitative ranking is based on the cumulative degradation resulting from these corrosion mechanisms. Table 3-20 contains the approximate average and worst internal depth of attack for the coupons.

Table 3-19 Qualitative Ranking of Long-Term Vapor Space Coupons

\begin{tabular}{|l|l|l|l|}
\hline Material & $400^{\circ} \mathrm{C}$ Zone & $600^{\circ} \mathrm{C}$ Zone & $900^{\circ} \mathrm{C}$ Zone \\
\hline 1 & Pt-Coated I-693 & Pt-Coated I-693 & I-693 \\
\hline 2 & SRTC Alloy/I-693* & MA 758 & Pt-Coated I-693 \\
\hline 3 & SRTC Alloy/I-693* & I-693 & SRTC Alloy \\
\hline 4 & MA 758 & SRTC Alloy & MA 758 \\
\hline
\end{tabular}

* Similar degradation seen in the two alloys.

Table 3-20 Internal Depth of Attack for Long-Term Vapor Space Coupons

\begin{tabular}{|c|c|c|}
\hline & \multicolumn{2}{|c|}{ Depth of Internal Attack } \\
\hline $\begin{array}{c}\text { Sample } \\
\text { Identification }\end{array}$ & $\begin{array}{c}\text { Average } \\
\mu \mathrm{m}\end{array}$ & $\begin{array}{c}\text { Maximum } \\
\mu \mathrm{m}\end{array}$ \\
\hline II-693 $400^{\circ} \mathrm{C}$ & $\overline{11}$ & 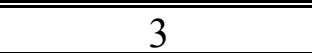 \\
\hline I- $693600^{\circ} \mathrm{C}$ & 28 & 55 \\
\hline I-693 $900^{\circ} \mathrm{C}$ & 14 & 21 \\
\hline MA $758400^{\circ} \mathrm{C}$ & 9 & 15 \\
\hline MA $758600^{\circ} \mathrm{C}$ & 39 & 61 \\
\hline MA $758900^{\circ} \mathrm{C}$ & 11 & 26 \\
\hline SRTC Alloy $400^{\circ} \mathrm{C}$ & None discernable & 4.9 \\
\hline SRTC Alloy $600^{\circ} \mathrm{C}$ & 22 & 81 \\
\hline SRTC Alloy $900^{\circ} \mathrm{C}$ & 16 & 33 \\
\hline Pt-Coated I-693 400 & None discernable & None discernable \\
\hline Pt-Coated I-693 $600^{\circ} \mathrm{C}$ & 18 & 19 \\
\hline Pt-Coated I-693 900 ${ }^{\circ} \mathrm{C}$ & 14 & 28 \\
\hline
\end{tabular}


WSRC-TR-2002-00588, REV. 0

SRT-RPP-2002-00283. REV. 0

Among the coupons from the $400^{\circ} \mathrm{C}$ region, the platinum-coated I-693 coupon showed no discernable degradation when compared to a micrograph of the cross section of an asreceived platinum-coated I-693 coupon plated at the same time as the vapor-space coupon. The MA 758 coupon showed the most degradation with metal loss apparent in the 20x SEM micrograph, and the deepest internal corrosion of the four coupons in the $400^{\circ} \mathrm{C}$ temperature zone. Both the SRTC alloy and the I-693 appeared similar in terms of metal loss. The I-693 coupon appeared to have a more even oxide coating than the SRTC alloy. The SRTC alloy did not, for the most part, have a discernable oxide layer at a 1000X magnification level. Figures 3-25 through 3-28 are SEM micrographs of the four coupons from the $400^{\circ} \mathrm{C}$ range. A bottom corner of the coupon is shown in cross section. See Appendices D and E for additional SEM micrographs and SEM-EDS scans.

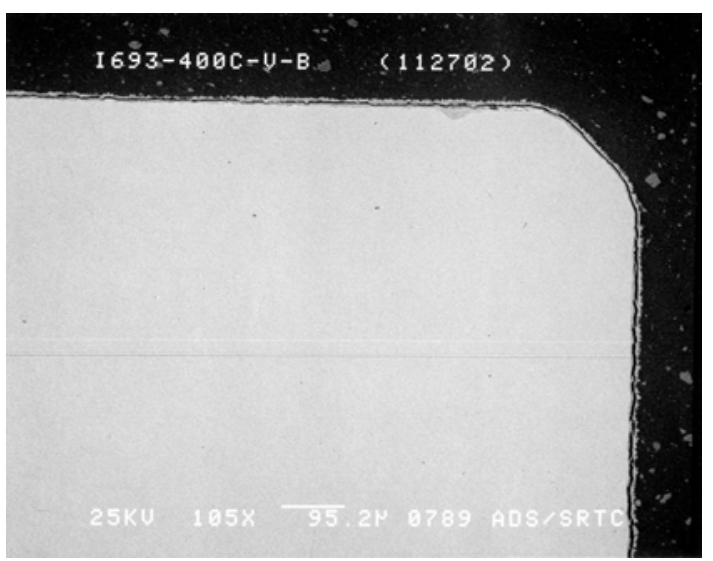

Figure 3-25 SEM Micrograph; I-693 at $400^{\circ} \mathrm{C}$ Cross Section

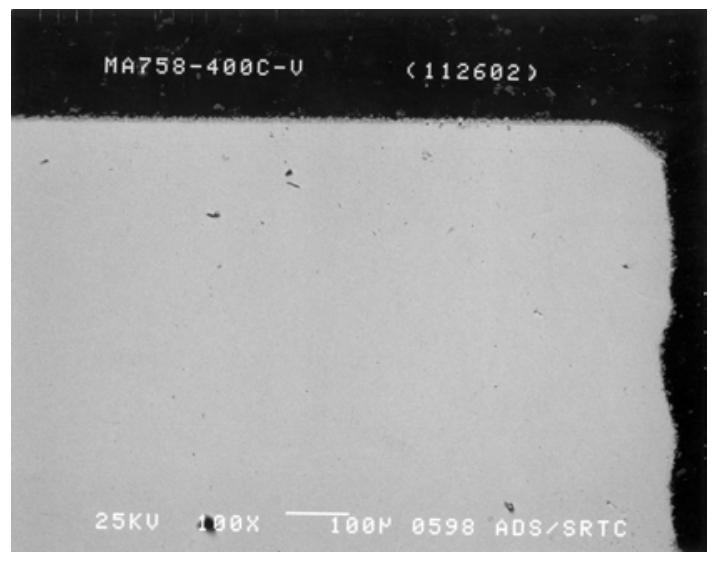

Figure 3-26 SEM Micrograph; MA 758 at $400^{\circ} \mathrm{C}$ Cross Section

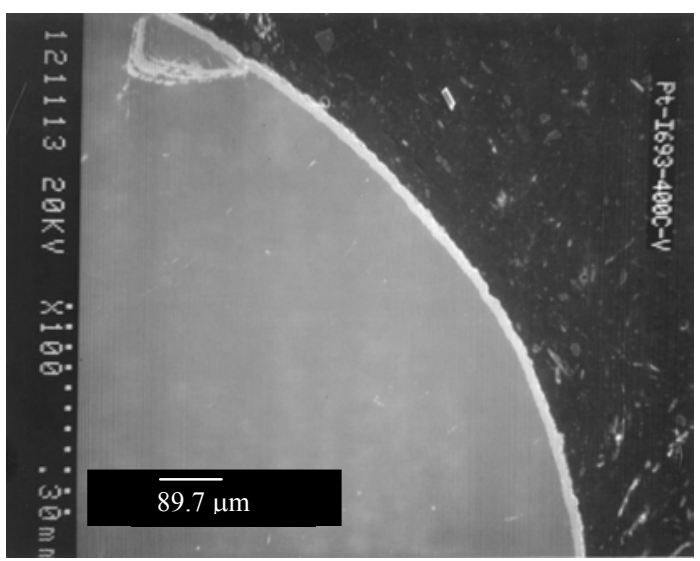

Figure 3-27 SEM; Pt-Coated I-693 at $400^{\circ} \mathrm{C}$ Cross Section

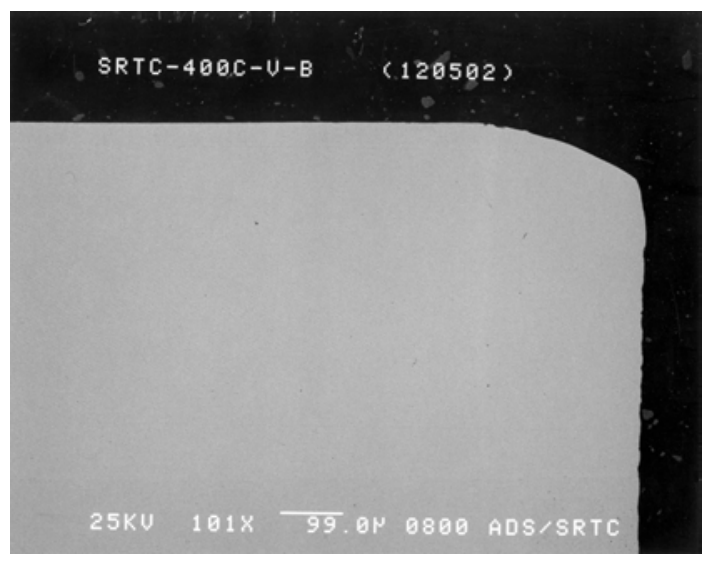

Figure 3-28 SEM; Micrograph; SRTC at $400^{\circ} \mathrm{C}$ Cross Section 
For the $600^{\circ} \mathrm{C}$ zone, the platinum-coated I-693 coupon showed the least depth of attack. Compared to the unprotected I-693 coupon, both the average and maximum depth of internal attack were lessened, and the metal loss appeared to be reduced. However, the platinum coating came off of large sections of the coupon and buckled at others, creating deeper penetrations of attack at those points (although still less than on the unprotected I693 coupon). The platinum coating appeared to have detached from the base metal. The thin $(<1 \mu \mathrm{m})$ underlying nickel flash layer was not discernable on the SEM micrograph. The MA 758 coupon had the greatest average depth of internal attack, but appeared to have the least amount of metal loss. Both the I-693 coupon and SRTC alloy coupons had greater metal loss than the MA 758 coupon and similar depths of internal attack. The maximum depth of internal attack was greater for the SRTC coupon than for the I-693 coupon, but at only one point on the bottom of the coupon was this depth reached. One notable difference between the SRTC alloy and the I-693 was that relatively large peaks of sulfur were evident on the SEM-EDS graphs at the deepest points of internal attack for the SRTC alloy. Very small peaks of sulfur and chlorine were seen at the deeper regions of internal attack for the I-693 coupon. Figures 3-29 through 3-32 are SEM photographs of the four coupons from the $600^{\circ} \mathrm{C}$ range. A bottom corner of the coupon is shown in cross section. See Appendices D and F for additional SEM photographs and SEM-EDS scans.

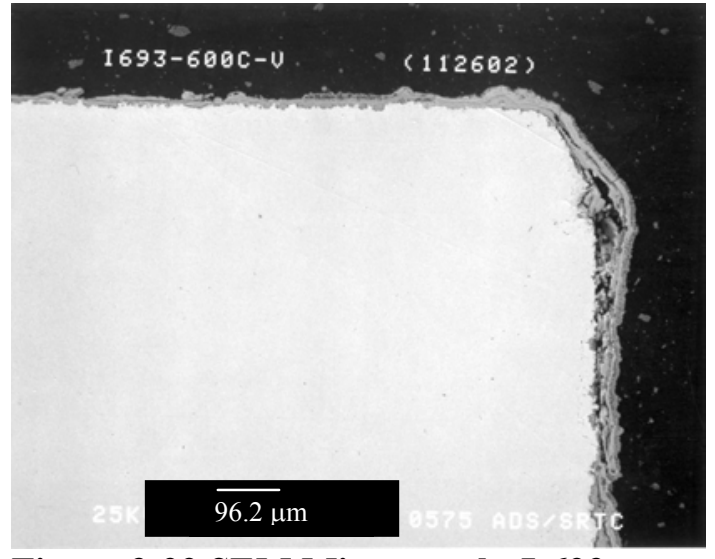

Figure 3-29 SEM Micrograph; I-693 at $6^{\circ}{ }^{\circ} \mathrm{C}$ Cross Section

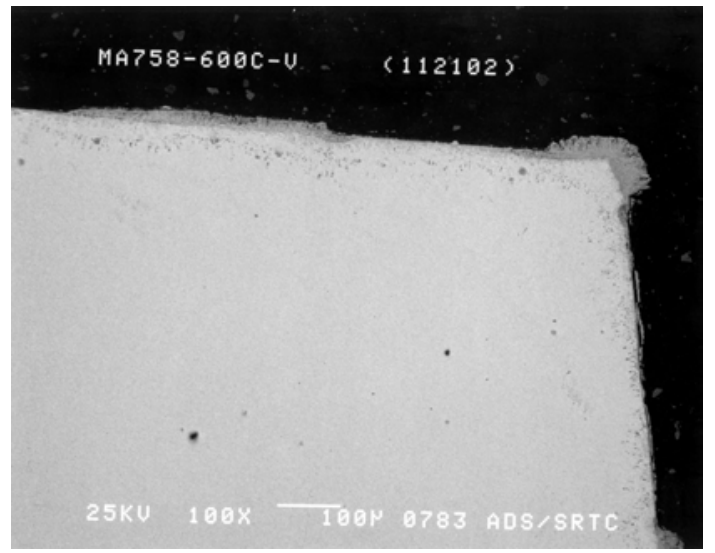

Figure 3-30 SEMMicrograph; MA 758 at $600^{\circ} \mathrm{C}$ Cross Section

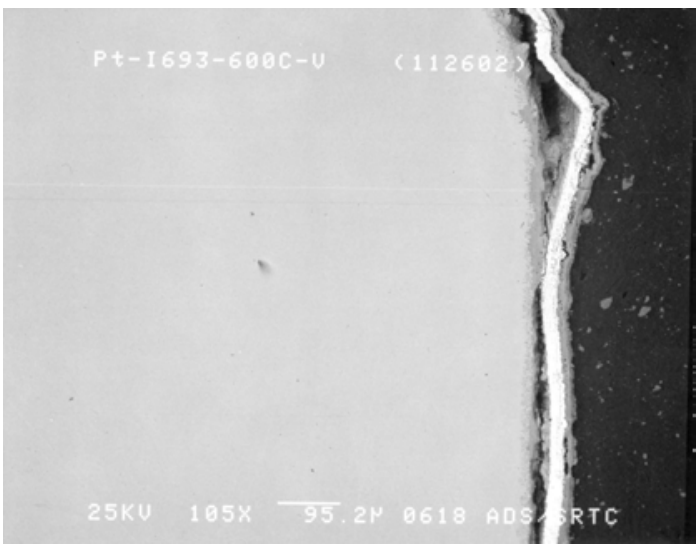

Figure 3-31 SEM; Pt-Coated I-693 at $6^{\circ 00} \mathrm{C}$ Cross Section

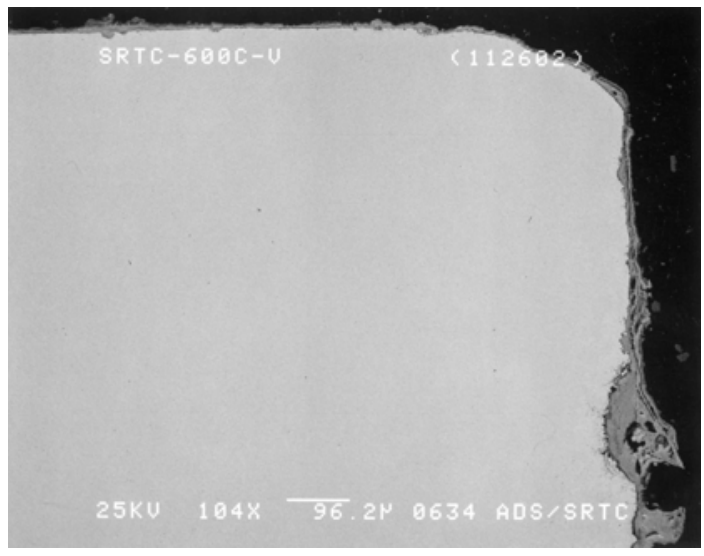

Figure 3-32 SEM; Micrograph; SRTC at $6^{600}{ }^{\circ} \mathrm{C}$ Cross Section 
WSRC-TR-2002-00588, REV. 0

SRT-RPP-2002-00283. REV. 0

Multiple layers of a Ni-Cr oxide were found on the outer surfaces of the four coupons in the $600^{\circ} \mathrm{C}$ zone, including on top of the platinum layer of the platinum-coated I-693 coupon. The Ni-Cr oxide may have deposited on the coupons from the feed or from material evolved from the coupons in the $900^{\circ} \mathrm{C}$ zone that were positioned upstream from the $600^{\circ} \mathrm{C}$ coupons. A second possibility is that the nickel and chromium diffused out to the surface of the $600^{\circ} \mathrm{C}$ coupons. For the uncoated alloys, regions of chromium depletion and some nickel depletion were found just beneath the surface of the cross sections. See Appendix F. However, on the cross section of the platinum-coated alloy, only chromium oxide was found diffused throughout the platinum layer; no nickel was present. See Figure 3-33. An additional vapor space experiment with only one set of coupons held at $600^{\circ} \mathrm{C}$ would be necessary to determine from where the $\mathrm{Ni}-\mathrm{Cr}$ oxide layer originated. Regardless, the $600^{\circ} \mathrm{C}$ zone coupons were compared in relation to one another, all having seen the same conditions. Additionally, the $600^{\circ} \mathrm{C}$ coupons did experience the greatest amount of corrosion of the coupons from the three temperature zones, as expected.

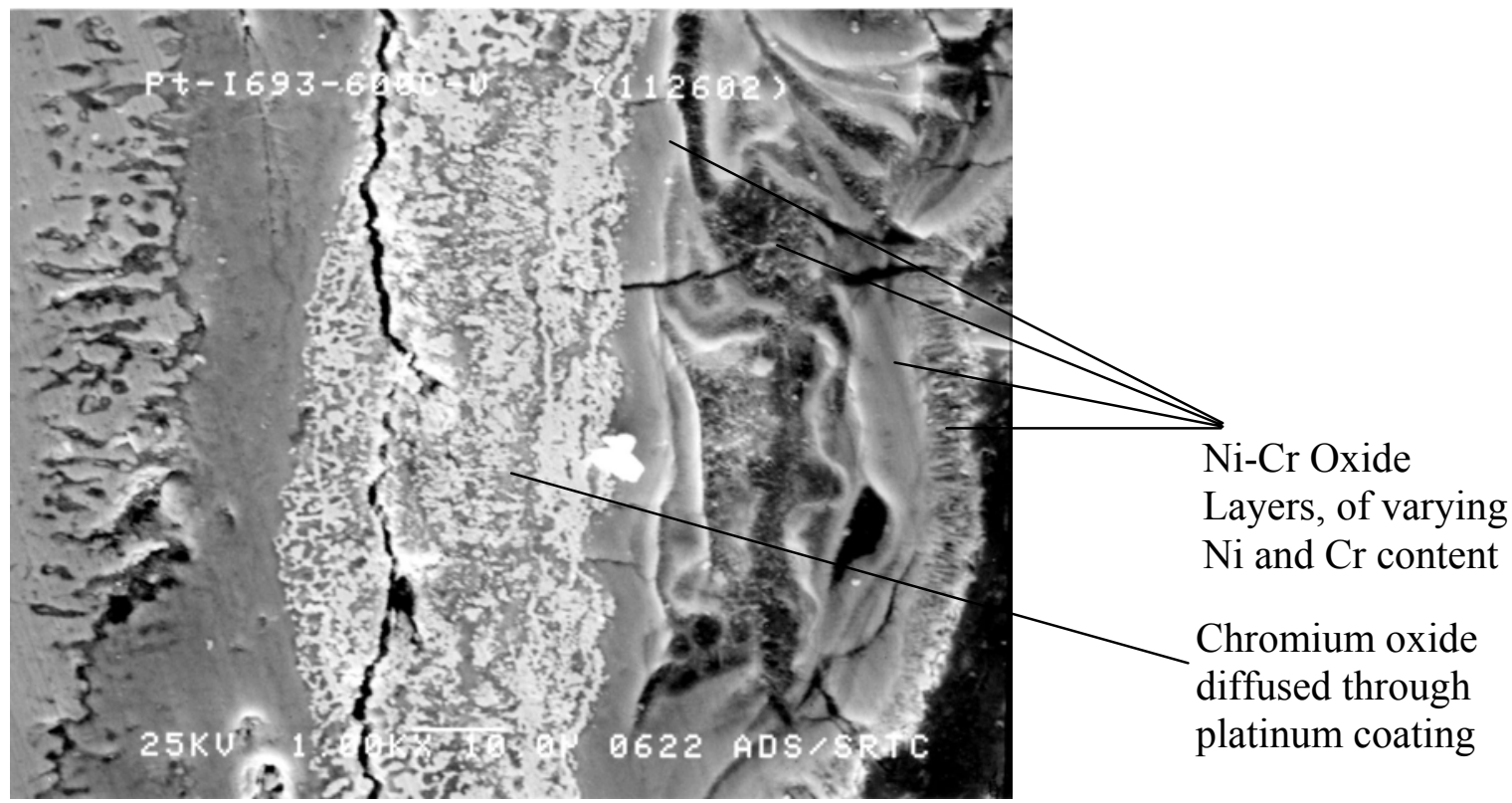

Figure 3-33 Cross Section of Pt-Coated I-693 Coupon Showing Layers of Ni-Cr Oxide on Surface of Coupon 
WSRC-TR-2002-00588, REV. 0

SRT-RPP-2002-00283. REV. 0

In the $900^{\circ} \mathrm{C}$ region, the extent of corrosion for all four samples was similar. Although the MA 758 had relatively low average internal attack, metal loss was noticeable on the 100X SEM micrograph. The SRTC alloy generally had a thicker layer of corrosion than the I-693 coupon or the platinum-coated I-693 coupon. The platinum coating on that coupon was missing in regions, and the maximum depth of internal attack was greater than on the uncoated I-693 coupon. Figures 3-34 through 3-37 are SEM micrographs of the four coupons from the $900^{\circ} \mathrm{C}$ range. A bottom corner of the coupon is shown in cross section. See Appendices D and E for additional SEM micrographs and SEM-EDS scans.

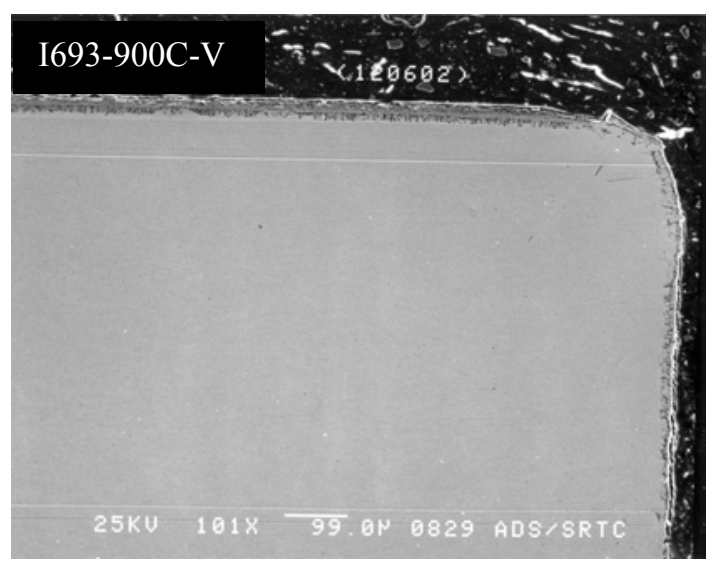

Figure 3-34 SEM Micrograph; I-693 at $900^{\circ} \mathrm{C}$ Cross Section

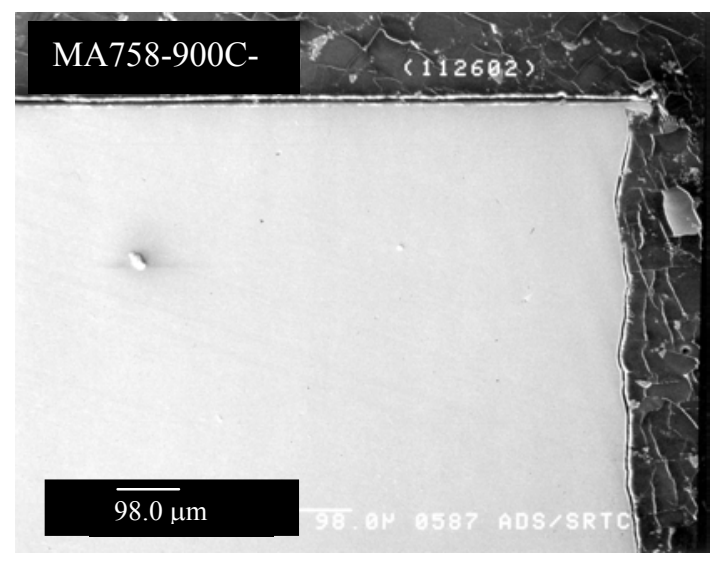

Figure 3-35 SEM Micrograph; MA 758 at $900^{\circ} \mathrm{C}$ Cross Section

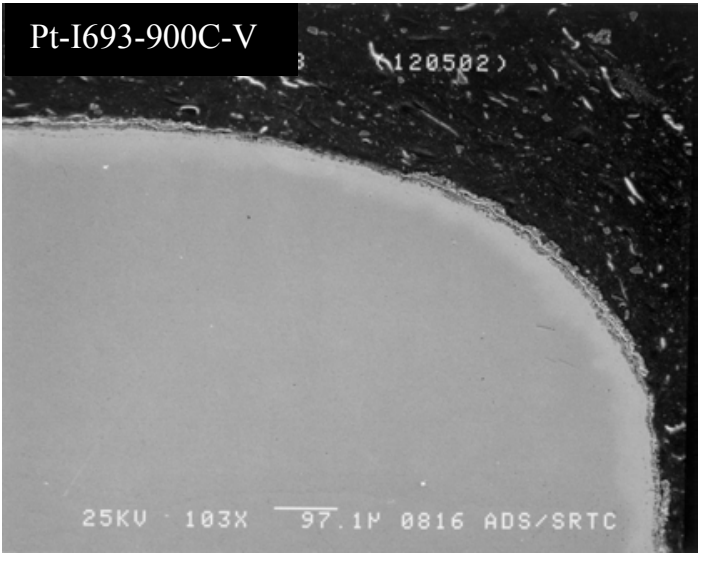

Figure 3-36 SEM; Pt-Coated I-693 at 900 $^{\circ} \mathrm{C}$ Cross Section

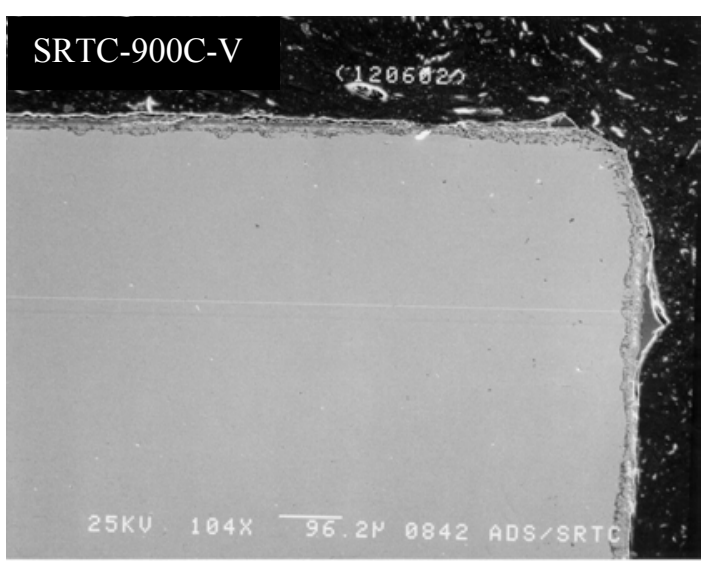

Figure 3-37 SEM; Micrograph; SRTC at $900^{\circ} \mathrm{C}$ Cross Section 
WSRC-TR-2002-00588, REV. 0

SRT-RPP-2002-00283. REV. 0

\subsection{BUBBLER M ATERIAL SELECTION AND FABRICATION}

A bubbler sub-assembly was fabricated and delivered to the RPP LLW melter pilot facility at Duratek, Inc. in Maryland. The sub-assembly was a two foot long $3 / 4$ " schedule 160 pipe made from the SRTC proprietary alloy. The alloy was forged at Allvac in North Carolina into a rod with a slightly larger diameter than the final product. The final outer diameter was machined at the Savannah River Site. The rod was then sent to Adron Tool Corp. in Wisconsin where the inner diameter was machined. The piece was first gun drilled to make a starter hole and then the inner diameter was finished using an EDM. The thickness of the wall of the sub-assembly was characterized over its length and diameter at SRS. Table 3-21 contains the data generated from the ultrasonic testing (UT) analysis.

Table 3-21 UT Measurements of Bubbler Sub-assembly

\begin{tabular}{|c|c|c|c|c|}
\hline \multirow{2}{*}{$\begin{array}{c}\text { Distance From } \\
\text { Top (in) }\end{array}$} & \multicolumn{4}{|c|}{ Position Around Pipe / Thickness (in) } \\
\cline { 2 - 5 } & $0^{\circ}$ & $90^{\circ}$ & $180^{\circ}$ & $270^{\circ}$ \\
\hline 0.125 & 0.231 & 0.228 & 0.228 & 0.235 \\
\hline 6.5 & 0.230 & 0.226 & 0.230 & 0.234 \\
\hline 13 & 0.228 & 0.227 & 0.236 & 0.235 \\
\hline 19.5 & 0.231 & 0.228 & 0.236 & 0.235 \\
\hline 25.875 & 0.232 & 0.229 & 0.236 & 0.236 \\
\hline
\end{tabular}

\subsection{ISSUES}

Generally molten glass attack is the focus of testing programs because it is one of the more aggressive environments. However, vapor corrosion, especially in the presence of mixed gases and salts, can be catastrophic. Melter and offgas components maintained at or cycled through critical temperature ranges can suffer severe degradation in very short time periods. This was the case for several critical components in the DWPF. These components were identified and modified during cold runs (non-radioactive operations). System modifications during radioactive operations would have presented a major engineering challenge and would have been extremely difficult to remotely install.

Similar issues are of concern for the RPP LAW melter system. The synergistic effects of $\mathrm{HCl}$ and chloride and sulfate salts can be extremely corrosive as shown in the current testing program. Some degradation was even seen in the $400{ }^{\circ} \mathrm{C}$ region. It is extremely difficult to model the complex environment inside the plenum and off gas system. Furthermore it is extremely difficult to locate coupons precisely in a full size melter system where the attack may occur therefore, laboratory testing of promising materials, alloys and coatings, is necessary in order identify areas of concern and predict performance. This will maximize service lives of critical components, minimize worker exposure, and ultimately reduce operating costs. 
WSRC-TR-2002-00588, REV. 0

SRT-RPP-2002-00283. REV. 0

Additional material testing in the molten glass region is necessary. Commercially available materials have shown some promise but work is still needed. Because this is a very specific environment and a very limited market, commercial vendors are not willing to expend much effort in developing more corrosion resistant materials. The use of platinum coatings is one option that has shown promise in actual melter tests and should be pursued. The selection of the optimal base metal, diffusion barriers, platinum alloy composition, surface finish, porosity and thermo-physical properties should be evaluated in order to optimize performance of the platinum coating. Barrier and functionally graded coatings are applied in the coating industry to optimize mechanical properties and corrosion resistance. Application of a barrier coating could be applied to the Inconel substrate before the corrosion resistant platinum coating to minimize diffusion of oxygen. Mechanical properties at ambient and elevated temperatures, along with oxidation and corrosion resistance must be evaluated to assess performance. Testing comparing the barrier-coated coupon with other platinum, platinum alloys, and platinum thermal spray coatings should then be performed. Alloy development is also possible but would require a longer-term effort. With a good understanding of the glass chemistry it would be possible to develop an alloy with increased corrosion resistance for this particular glass chemistry.

Total degradation in the molten glass tests was based on metal loss and internal attack. Close examination of components from the Duratek melter should be performed to correlate test data with actual component degradation. This would involve a thorough metallurgical evaluation of each failed melter component.

\subsection{FUTURE WORK}

Melter and offgas components will be subject to very corrosive mixed gas and salt environment. Future testing for verification of current materials of construction and alternate materials/coatings in a vapor environment should include the following:

- $\quad$ Longer-term tests to fully evaluate initiation and propagation times.

- $\quad$ Testing to encompass the entire temperature range between 400 and $900{ }^{\circ} \mathrm{C}$ to ensure identification of the most aggressive temperature region. In addition, add a temperature region consistent with the temperature near the glass/air interface ( $\sim 1100 \mathrm{C})$. Mass Spec data should be captured in various temperature regions.

- $\quad$ Material performance testing in elevated temperature environments with only $\mathrm{HCl}$.

- $\quad$ Testing to evaluate microstructural effects, i.e., grain orientation or cast vs. wrought structure effects.

- $\quad$ Evaluate alternate feed compositions or ranges to test alloy/coating performance and to establish process limits, i.e. glass chemistry and melt/offgas system temperatures.

Future tests in molten glass and air/glass interface that should be pursued are as follows: 
WSRC-TR-2002-00588, REV. 0

SRT-RPP-2002-00283. REV. 0

- $\quad$ Optimization of material and application parameters for the platinum coating and base metal.

- Development of weld parameters and mechanical property data critical to the successful operation of the SRTC alloy at elevated temperatures.

- Development of an alloy specifically designed for the anticipated feed chemistry. 
WSRC-TR-2002-00588, REV. 0

SRT-RPP-2002-00283. REV. 0

APPENDIX A. Simulant and Glass Feed Information

Page A-1 of 54 
WSRC-TR-2002-00588, REV. 0

SRT-RPP-2002-00283. REV. 0

Figure A-1 is the chain of custody form for the simulant melter feed and glass used in the experiments. It contains the batch names and numbers from both VSL and Optimal Chemical Corporation.

CHAIN OF CUSTODY RECORD

TO: Kathy Marshall, SRTC

FROM: Kenneth Hight, VSL

RE: Chain of Custody for Sample Shipment

\begin{abstract}
Please find enclosed three pages from the VSL-01T8800-2 Test Plan Revision 1. These pages detail the components of the glass and feed that were received at your facility on $4 / 25 / 02.4 / 26 / 02$. $\mathrm{kMM} \mathrm{s}-23-02$

The approximately $55 \mathrm{~kg}$ of feed sent, sample ID: $12 \mathrm{~V}-\mathrm{F}-42$, was purchased from Optima Chemical Corporation, it arrived at our facility on $3 / 3 / 02$. Its receipt is documented in VSL logbook 995-02 page 15. Optima named the feed DM12LA44 FEED FOR AN105. The VSL ID for the feed was OPTFEED 15 . The feed sent was a mixture of OPTFEED 15 and sugar. The mixing of the feed is documented in VSL Logbook 1017-02 Page 21. The MATERIAL INVENTORY CONTROL FORM for the feed is in VSL 1019-02 page D6.
\end{abstract}

The approximately $24.3 \mathrm{~kg}$ of glass that was shipped, sample ID $12 \mathrm{~V}-\mathrm{G}-89$, was generated during a DM1 200 melter run. It was generated from another feed purchased from Optima; VSL ID: OPTFEED 16. Its receipt is documented in VSL Logbook 995-02 page 15. Optima named the feed DM12LA44 FEED WITH FORMIC ACID. The transfer of this feed is documented in VSL Logbook 1017-02 page 73. The glass was discharged on 3/20/02 at 22:44. The discharge of the glass is documented in VSL Logbook 1017-01 page 89, and its MATERIAL INVENTORY CONTROL FORM is in VSL logbook 993-02 page D342.

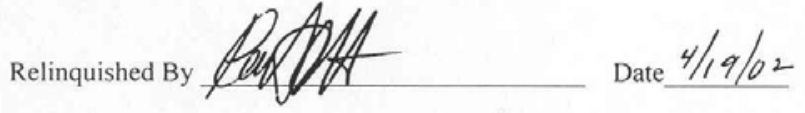

Received By Kathon Martall Date $5-2302$ Received 4/26102

Please Sign and fax back a copy to 202-319-4469.

If you have any questions please contact me at 202-319-5524.

Thanks

Kenneth Hight

Figure A-1 Chain of Custody Form for the Glass and Melter Feed Simulant

Page A-2 of 54 
WSRC-TR-2002-00588, REV. 0 SRT-RPP-2002-00283. REV. 0

Table A-1 RPP LAW Envelope A Simulant Melter Feed with Additives, used in Long-Term Vapor Space Study

Simulant Melter Feed Sodium Peroxide Fusion ICP Data

Concentration in wt\%

\begin{tabular}{cccc}
\hline & LAW SIM & LAW SIM & AVERAGE \\
& $\mathrm{A} 1$ & $\mathrm{~A} 2$ & \\
\hline & & & \\
$\mathrm{Al}_{2} \mathrm{O}_{3}$ & 5.00 & 4.88 & 4.94 \\
$\mathrm{~B}_{2} \mathrm{O}_{3}$ & 8.31 & 8.34 & 8.32 \\
$\mathrm{CdO}$ & 0.09 & 0.09 & 0.09 \\
$\mathrm{Fe}_{2} \mathrm{O}_{3}$ & 4.75 & 4.68 & 4.71 \\
$\mathrm{MgO}$ & 0.14 & 0.14 & 0.14 \\
$\mathrm{SiO}$ & 29.74 & 29.52 & 29.63 \\
$\mathrm{SrO}$ & 0.00 & 0.00 & 0.00 \\
$\mathrm{TiO}_{2}$ & 1.67 & 1.64 & 1.65 \\
$\mathrm{ZnO}$ & 2.48 & 2.40 & 2.44 \\
$\mathrm{ZrO}_{2}$ & 1.30 & 1.31 & 1.30 \\
\hline
\end{tabular}

\section{Simulant Melter Feed Lithium Tetraborate Fusion ICP Data}

Concentration in wt $\%$

\begin{tabular}{cccc}
\hline & LAW SIM & LAW SIM & AVERAGE \\
& $\mathrm{A} 1$ & $\mathrm{~A} 2$ & \\
\hline & & & \\
$\mathrm{Al}_{2} \mathrm{O}_{3}$ & 4.99 & 4.95 & 4.97 \\
$\mathrm{BaO}$ & 0.004 & 0.004 & 0.00 \\
$\mathrm{CaO}$ & 1.46 & 1.47 & 1.46 \\
$\mathrm{Cr}_{2} \mathrm{O}_{3}$ & 0.011 & 0.010 & 0.01 \\
$\mathrm{Fe}_{2} \mathrm{O}_{3}$ & 4.69 & 4.70 & 4.70 \\
$\mathrm{MgO}$ & 0.15 & 0.15 & 0.15 \\
$\mathrm{MnO}$ & 0.003 & 0.003 & 0.00 \\
$\mathrm{Na}_{2} \mathrm{O}$ & 17.44 & 17.58 & 17.51 \\
$\mathrm{NiO}$ & 0.005 & 0.005 & 0.01 \\
$\mathrm{SiO}$ & 30.59 & 30.16 & 30.38 \\
$\mathrm{SrO}$ & 0.001 & 0.001 & 0.00 \\
$\mathrm{TiO}_{2}$ & 1.70 & 1.70 & 1.70 \\
$\mathrm{ZnO}_{\mathrm{ZrO}}$ & 2.45 & 2.50 & 2.48 \\
$\mathrm{~K}_{2} \mathrm{O}$ & 1.38 & 1.36 & 1.37 \\
\hline
\end{tabular}


WSRC-TR-2002-00588, REV. 0

SRT-RPP-2002-00283. REV. 0

\section{Mullite vs. Platinum Crucible Usage for Long-Term Vapor Experiment}

The sulfur, chlorine, and phosphorous content of VSL melter feed vitrified in a mullite crucible was compared to the content of glass produced in a $95 / 5$ platinum/gold crucible. The experiment was done to determine if the mullite absorbed any of these species or if it affected the rate of evolution of the species. The mullite crucibles used were part number C3 Colorado CC500099021538 from DFC Ceramic Sales. The platinum crucibles were 95/5 platinum/gold. Table A-2 contains the complete data from the tests.

Table A-2 Complete Data for Mullite vs. Platinum Crucible Test

\begin{tabular}{|l|l|l|l|}
\hline & $\mathrm{Cl}$ (kcps) & $\mathrm{P}(\mathrm{kcps})$ & $\mathrm{S}(\mathrm{kcps})$ \\
\hline Binder Blank & & & \\
\hline Paraffin & 0 & 0 & 0.0327 \\
\hline Crucible Blank (No Glass) & & & \\
\hline Crucible 1 day heated to $1150^{\circ} \mathrm{C}$ & 0 & 0.4357 & 0.0390 \\
\hline New Crucible & 0 & 0.4357 & 0.0301 \\
\hline Envelope A Feed Stock & & & \\
\hline 1 day in mullite @ $1150^{\circ} \mathrm{C}$ & 0.9851 & 0.4115 & 0.5141 \\
\hline 1 day in mullite $@ 1150^{\circ} \mathrm{C}$ & 0.9451 & 0.4048 & 0.4900 \\
\hline Average & 0.9651 & 0.4082 & 0.5021 \\
\hline & & & \\
\hline 1 day in Pt @ $1150^{\circ} \mathrm{C}$ & 0 & 0.5556 & 0.9970 \\
\hline 1 day in Pt @ $1150^{\circ} \mathrm{C}$ & 0 & 0.5443 & 0.8808 \\
\hline Average & 0 & 0.5500 & 0.9389 \\
\hline
\end{tabular}


WSRC-TR-2002-00588, REV. 0

SRT-RPP-2002-00283. REV. 0

\section{APPENDIX B. XRF SAMPLE PREPARATION AND} INSTRUMENTATION

Page A-5 of 54 


\section{XRF Sample Preparation}

The glass was cut out of the mullite crucibles using the diamond saw in the SRTC Glass Shop. A portion of the glass was placed in an agate mortar and pestle and ground for 15-20 minutes in ethanol to reduce the average particle size to $<10 \mu \mathrm{m} .8 .5$ grams of the ground glass was mixed thoroughly by hand with 1.5 grams of Spex Certiprep 3646 Paraffin Binder. This mixture was poured into a stainless steel die with tungsten carbide mandrels. The mandrels were covered with sheets of Spex Certiprep $4 \mu \mathrm{m}$ UltraLene film to minimize cross contamination. The ground glass sample was pressed at 20 tons for 3 minutes into a dense durable pellet in a Spex 3624B X-Press Model\# 3624B.

\section{Instrumentation}

A Rigaku 3271 wavelength dispersive x-ray fluorescence spectrometer was used for determining the elemental composition of these glasses. This is a sequential instrument with $3 \mathrm{~kW}$ maximum power, equipped with a side window $\mathrm{Rh}$ x-ray tube (125 $\mu \mathrm{m}$ Be window), eight analyzing crystals, scintillation and gas flow proportional counters, two collimators, and a six-position sample chamber. An ultra thin $0.6 \mu \mathrm{m}$ aluminized Mylar window was installed on the gas flow proportional detector to provide maximum light element sensitivity. All measurements were carried out in vacuum. A complete summary of all the measurement parameters is listed in Table 1.

The instrument was calibrated with five glass standards to cover the full range of elements found in RPP waste glass. See Table 2 for a list of standard compositions. The Rigaku Fundamental Parameter (FP) software package (Version 5.0) was used for calibrating the instrument and determining the major elements concentrations in the samples. The boron concentration was fixed at the value determined by ICP-ES for the sample in the FP routine. 
WSRC-TR-2002-00588, REV. 0

SRT-RPP-2002-00283. REV. 0

Table B-1 Rigaku 3271 Wavelength-dispersive X-ray Fluorescence Spectrometer Parameters

\begin{tabular}{|c|c|c|c|c|c|c|c|c|c|}
\hline Oxide & Line & Analyte & $\begin{array}{l}{ }^{\circ} 2 \text { Theta } \\
\text { Bkg1 }\end{array}$ & Bkg2 & Analyte & $\begin{array}{c}\text { me (s) } \\
\text { Bkg1 }\end{array}$ & Bkg2 & Crystal & Detector \\
\hline $\mathrm{Al}_{2} \mathrm{O}_{3}$ & $\mathbf{K} \alpha$ & 145.04 & 140 & & 40 & 20 & & PET & PC \\
\hline $\mathrm{CaO}$ & $\mathbf{K} \alpha$ & 113.41 & 110 & & 60 & 30 & & LiF200 & PC \\
\hline $\mathrm{Cr}_{2} \mathrm{O}_{3}$ & $\mathbf{K} \alpha$ & 69.515 & 68.5 & 71 & 60 & 30 & 30 & LiF200 & SC \\
\hline $\mathrm{Fe}_{2} \mathrm{O}_{3}$ & $\mathbf{K} \alpha$ & 57.68 & 59 & & 20 & 10 & & LiF200 & SC \\
\hline $\mathrm{K}_{2} \mathrm{O}$ & $\mathbf{K} \alpha$ & 136.955 & 140 & & 60 & 30 & & LiF200 & PC \\
\hline $\mathrm{MgO}$ & $\mathbf{K} \alpha$ & 21.62 & 20.93 & 22.28 & 600 & 300 & 300 & RX35 & PC \\
\hline $\mathrm{MnO}$ & $\mathbf{K} \alpha$ & 63.135 & 64 & & 60 & 30 & & LiF200 & SC \\
\hline $\mathrm{Na}_{2} \mathrm{O}$ & $\mathbf{K} \alpha$ & 26.19 & 24 & 28.5 & 40 & 20 & 20 & RX35 & PC \\
\hline $\mathrm{P}_{2} \mathrm{O}_{5}$ & $\mathbf{K} \alpha$ & 141.385 & 138 & 143 & 60 & 30 & 30 & GE & PC \\
\hline $\mathrm{SiO}_{2}$ & $\mathbf{K} \alpha$ & 144.855 & 140 & & 10 & 5 & & RX4 & PC \\
\hline $\mathrm{TiO}_{2}$ & $\mathbf{K} \alpha$ & 86.44 & 90 & & 60 & 30 & & LiF200 & PC \\
\hline $\mathrm{ZnO}$ & $\mathbf{K} \alpha$ & 41.96 & 40.5 & & 40 & 20 & & LiF200 & SC \\
\hline $\mathrm{ZrO}_{2}$ & $\mathbf{K} \alpha$ & 22.715 & 21.7 & & 20 & 10 & & LiF200 & SC \\
\hline $\mathrm{SO}_{3}$ & $\mathbf{K} \alpha$ & 111.08 & 108 & & 40 & 20 & & GE & PC \\
\hline $\mathrm{Cl}$ & $\mathbf{K} \alpha$ & 93.215 & 92.1 & 94.5 & 60 & 30 & 30 & GE & PC \\
\hline Power: & \multicolumn{9}{|c|}{$50 \mathrm{kV}, 50 \mathrm{~mA}$} \\
\hline GE: & \multicolumn{9}{|c|}{0.566 nm Ge Crystal } \\
\hline PET: & \multicolumn{9}{|c|}{$0.874 \mathrm{~nm}$ Pentaerythritol Crystal } \\
\hline RX4: & \multicolumn{9}{|c|}{$0.748 \mathrm{~nm}$ In/Sb Crystal } \\
\hline RX35: & \multicolumn{9}{|c|}{$5.5 \mathrm{~nm}$ W/Si Multilayer } \\
\hline PC: & \multicolumn{9}{|c|}{ Gas Flow Proportional Detector using P10 Gas } \\
\hline SC: & \multicolumn{9}{|c|}{ Scintillation Detector } \\
\hline
\end{tabular}

Page A-7 of 54 
WSRC-TR-2002-00588, REV. 0

SRT-RPP-2002-00283. REV. 0

Table B-2 Glass Standards

\begin{tabular}{|c|c|c|c|c|c|c|c|c|c|c|c|c|}
\hline Glass & $\begin{array}{c}\mathrm{Al}_{2} \mathrm{O}_{3} \\
\mathrm{wt} \%\end{array}$ & $\begin{array}{l}\mathrm{B}_{2} \mathrm{O}_{3} \\
\mathrm{wt} \%\end{array}$ & $\begin{array}{l}\mathrm{BaO} \\
\mathrm{wt} \%\end{array}$ & $\begin{array}{l}\mathrm{CaO} \\
\mathrm{wt} \%\end{array}$ & $\begin{array}{c}\mathrm{Cr}_{2} \mathrm{O}_{3} \\
\mathrm{wt} \%\end{array}$ & $\begin{array}{l}\text { CuO } \\
\text { wt } \%\end{array}$ & $\begin{array}{c}\mathrm{Fe}_{2} \mathrm{O}_{3} \\
\mathbf{w t} \%\end{array}$ & $\begin{array}{l}\mathrm{K}_{2} \mathrm{O} \\
\mathrm{wt} \%\end{array}$ & $\begin{array}{l}\mathrm{Li}_{2} \mathrm{O} \\
w t \%\end{array}$ & $\begin{array}{l}\text { MgO } \\
\text { wt } \%\end{array}$ & $\begin{array}{c}\mathrm{MnO}_{2} \\
\mathrm{wt} \%\end{array}$ & $\begin{array}{c}\mathrm{MoO}_{3} \\
\mathbf{w t} \%\end{array}$ \\
\hline WCP-1 Blend* & 4.16 & 8.05 & 0.18 & 1.03 & 0.13 & 0.44 & 10.91 & 3.68 & 4.44 & 1.41 & 2.05 & 0.15 \\
\hline NIST 93a & 2.28 & 12.56 & & 0.01 & & & 0.028 & 0.014 & & 0.005 & & \\
\hline NIST 620 & 1.8 & & & 7.11 & & & 0.043 & 0.41 & & 3.69 & & \\
\hline NIST 1411 & 5.68 & 10.94 & 5.00 & 2.18 & & & 0.05 & 2.97 & & 0.33 & & \\
\hline NIST 1834 & 45.23 & & 0.08 & 0.15 & & & 0.53 & 1.17 & & 0.17 & & \\
\hline
\end{tabular}

\begin{tabular}{|c|c|c|c|c|c|c|c|c|c|c|c|}
\hline Glass & $\begin{array}{c}\mathrm{Na}_{2} \mathrm{O} \\
\mathrm{wt} \%\end{array}$ & $\begin{array}{c}\mathrm{Nd}_{2} \mathrm{O}_{3} \\
\mathrm{wt} \%\end{array}$ & $\begin{array}{l}\mathrm{NiO} \\
\mathrm{wt} \%\end{array}$ & $\begin{array}{l}\mathrm{P}_{2} \mathrm{O}_{5} \\
\mathrm{wt} \% \\
\end{array}$ & $\begin{array}{l}\mathrm{SiO}_{2} \\
\mathrm{wt} \%\end{array}$ & $\begin{array}{l}\text { SrO } \\
\text { wt \% }\end{array}$ & $\begin{array}{l}\mathrm{TiO}_{2} \\
\mathrm{wt} \%\end{array}$ & $\begin{array}{l}\mathrm{ZrO}_{2} \\
\mathrm{wt} \%\end{array}$ & $\begin{array}{l}\text { ZnO } \\
\text { wt } \%\end{array}$ & $\begin{array}{c}\mathrm{Cl} \\
\mathrm{wt} \%\end{array}$ & $\begin{array}{l}\mathrm{SO}_{3} \\
\mathrm{wt} \% \\
\end{array}$ \\
\hline WCP-1 Blend & 9.13 & 0.22 & 0.89 & & 51.9 & & 0.89 & 0.14 & & & \\
\hline NIST 620 & 14.39 & & & & 72.08 & & 0.018 & & & & 0.28 \\
\hline NIST 1411 & 10.14 & & & & 58.04 & 0.09 & 0.02 & & 3.85 & & \\
\hline NIST 1834 & & & & 0.40 & 49.92 & 0.21 & 2.14 & & & & \\
\hline
\end{tabular}

Blank space denotes analysis not performed/provided by manufacturer

* See Carol Jantzen's notebook \# E56053 for the Corning Engineering Laboratory (CELS) data for the Blend glass.

The NIST 1834 standard was corrected for LOI. 
WSRC-TR-2002-00588, REV. 0

SRT-RPP-2002-00283. REV. 0

\section{APPENDIX C. SEM MICROGRAPHS FOR MOLTEN GLASS EXPERIMENT}


WSRC-TR-2002-00588, REV. 0 SRT-RPP-2002-00283. REV. 0
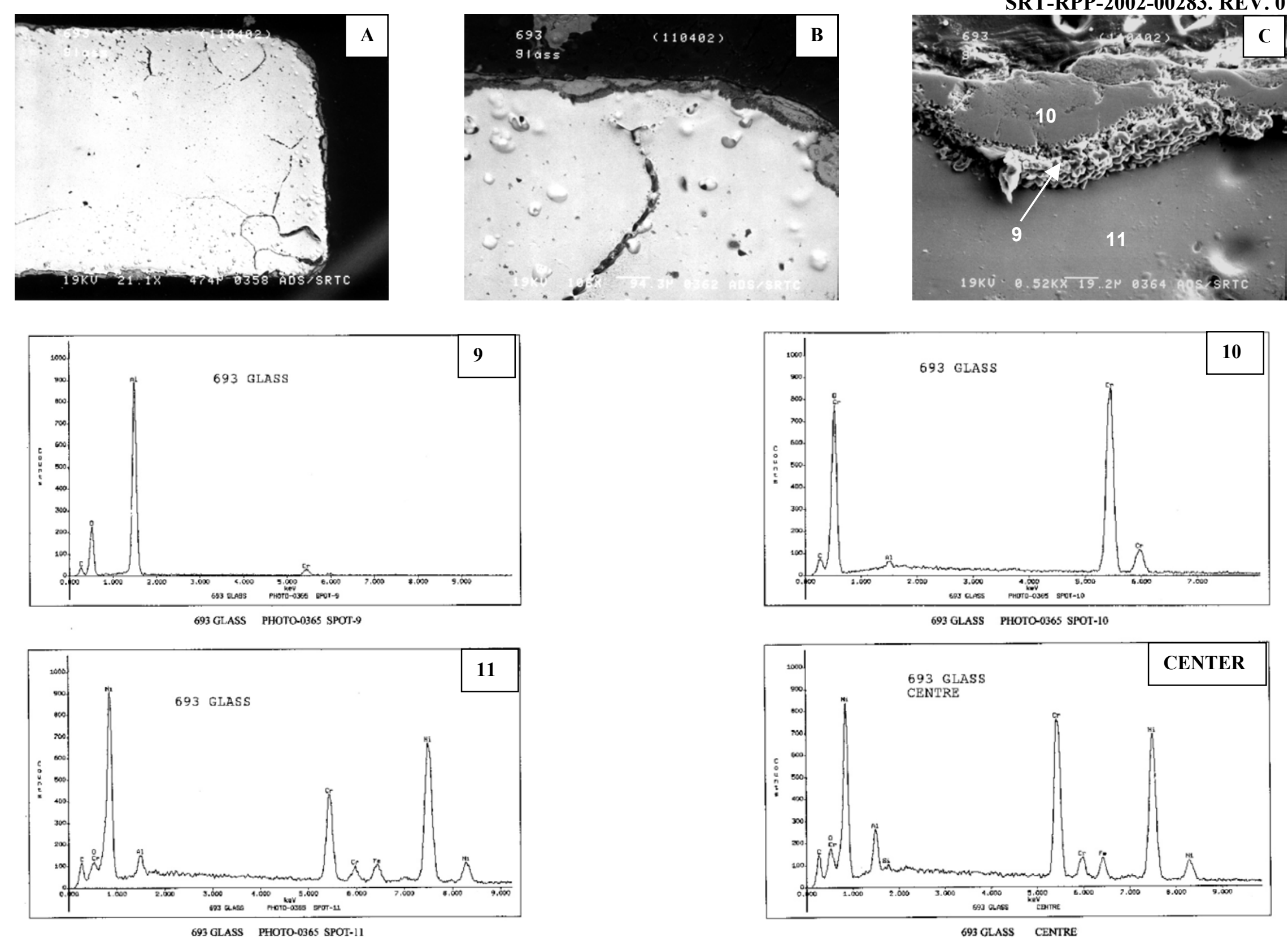

Figure C-1 SEM Photographs and EDS analyses from the glass contact region of the Inconel 693 coupon. Page A-10 of 54 
WSRC-TR-2002-00588, REV. 0 SRT-RPP-2002-00283. REV. 0
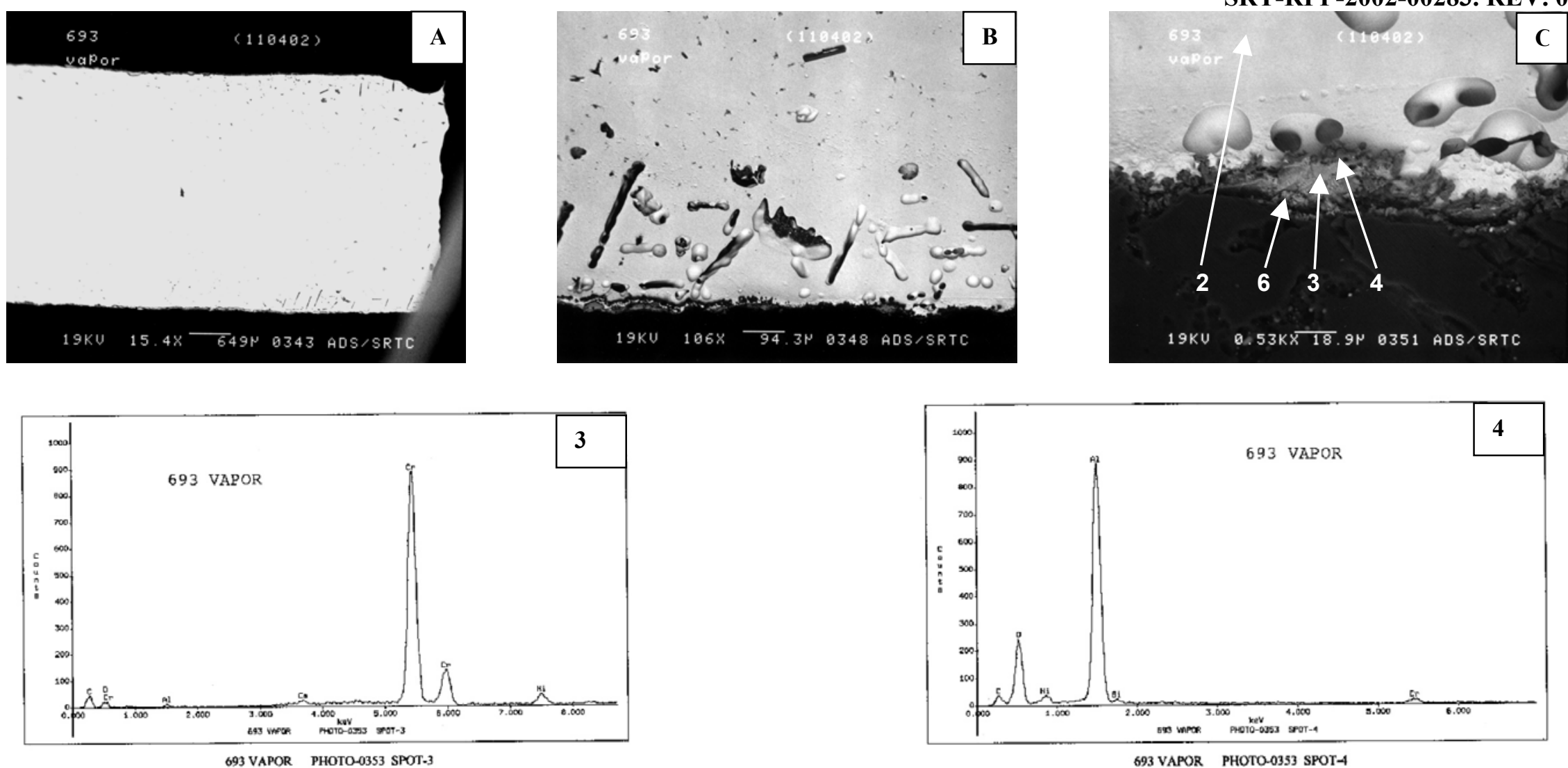

693 VAPOR PHOTO-0353 SPOT-4
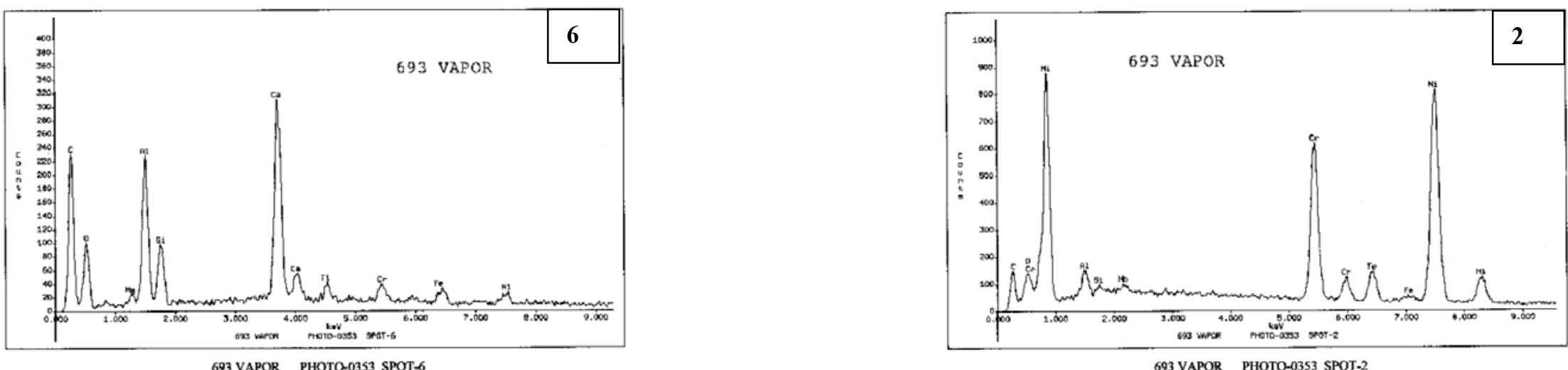

Figure C-2 SEM Photographs and EDS analyses from the vapor space region of the Inconel 693 coupon. 
WSRC-TR-2002-00588, REV. 0 SRT-RPP-2002-00283. REV. 0
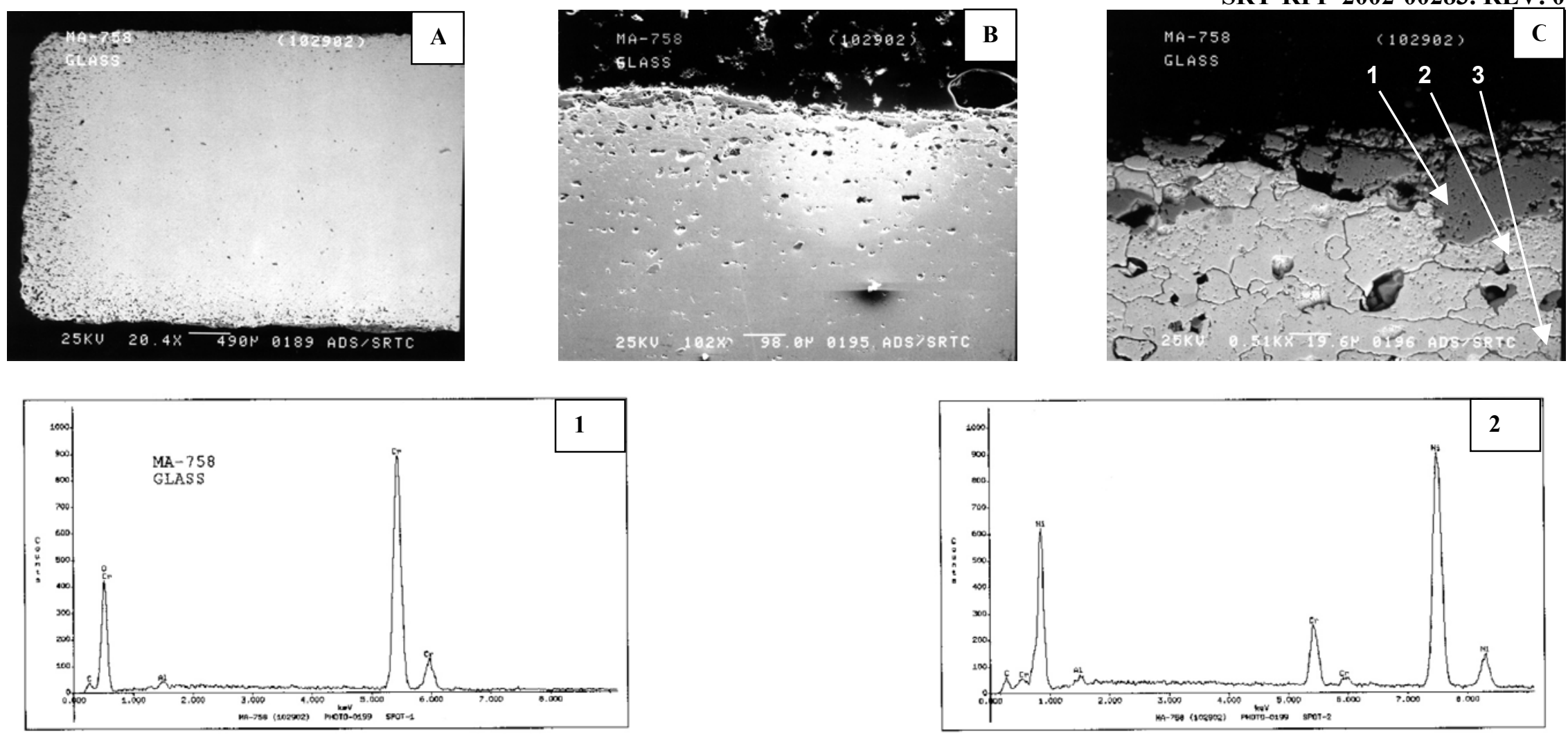

MA-758 (102902) PHOTO-0199 SPOT-1

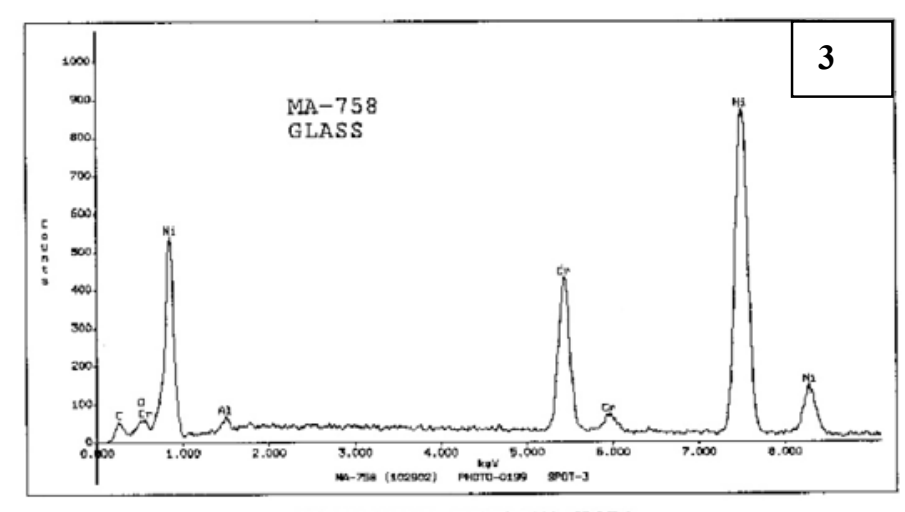

MA-758 (102902) PHOTO-0199 SPOT-2

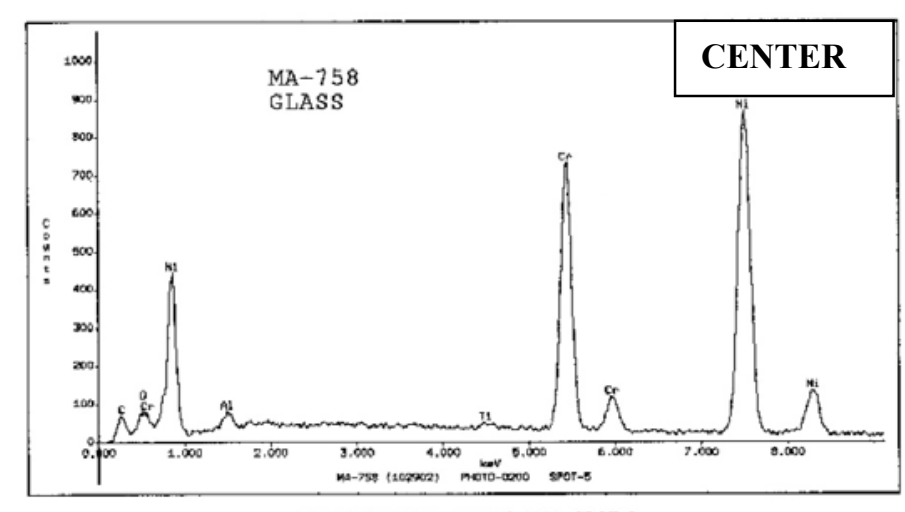

MA-758 (102902) PHOTO-0200 SPOT-5

Figure C-3 SEM Photographs and EDS analyses from the glass contact region of the Inconel MA 758 coupon.

Page A-12 of 54 
WSRC-TR-2002-00588, REV. 0 SRT-RPP-2002-00283. REV. 0
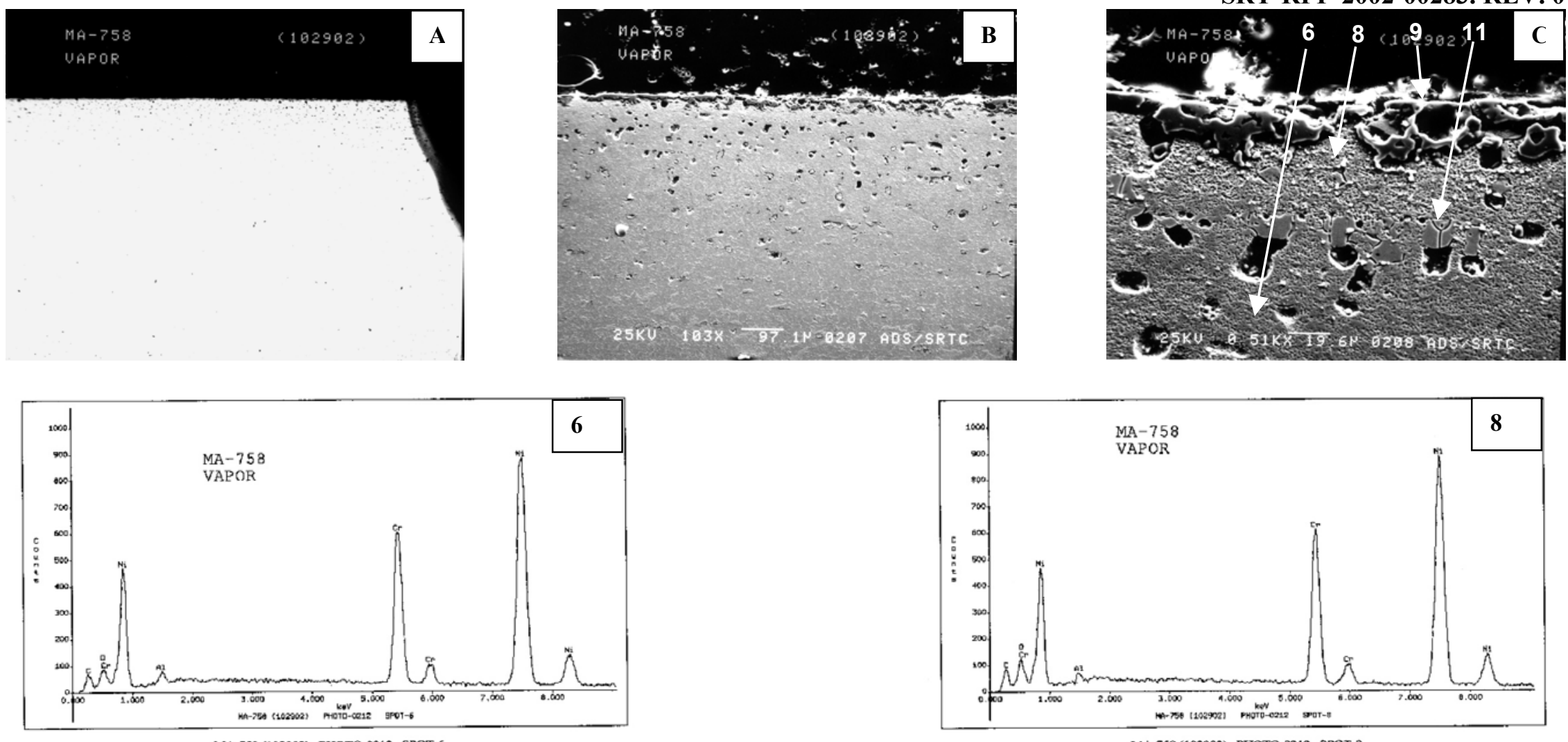

MA-758 (102902) PHOTO-0212 SPOT-6
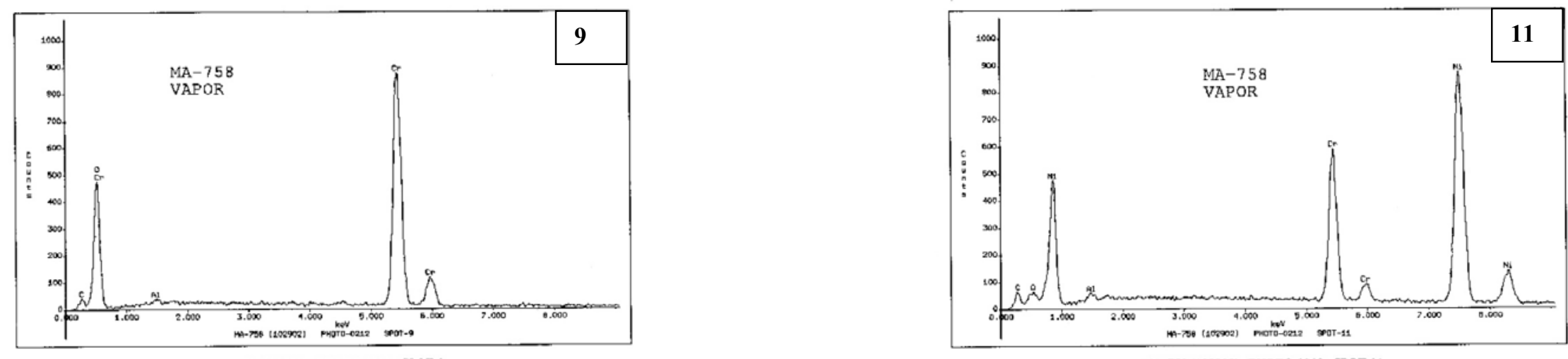

A.758 (102902) PHOTO-0212 SPOT-11

Figure C-4 SEM Photographs and EDS analyses from the vapor space region of the Inconel MA 758 coupon. 
WSRC-TR-2002-00588, REV. 0 SRT-RPP-2002-00283. REV. 0
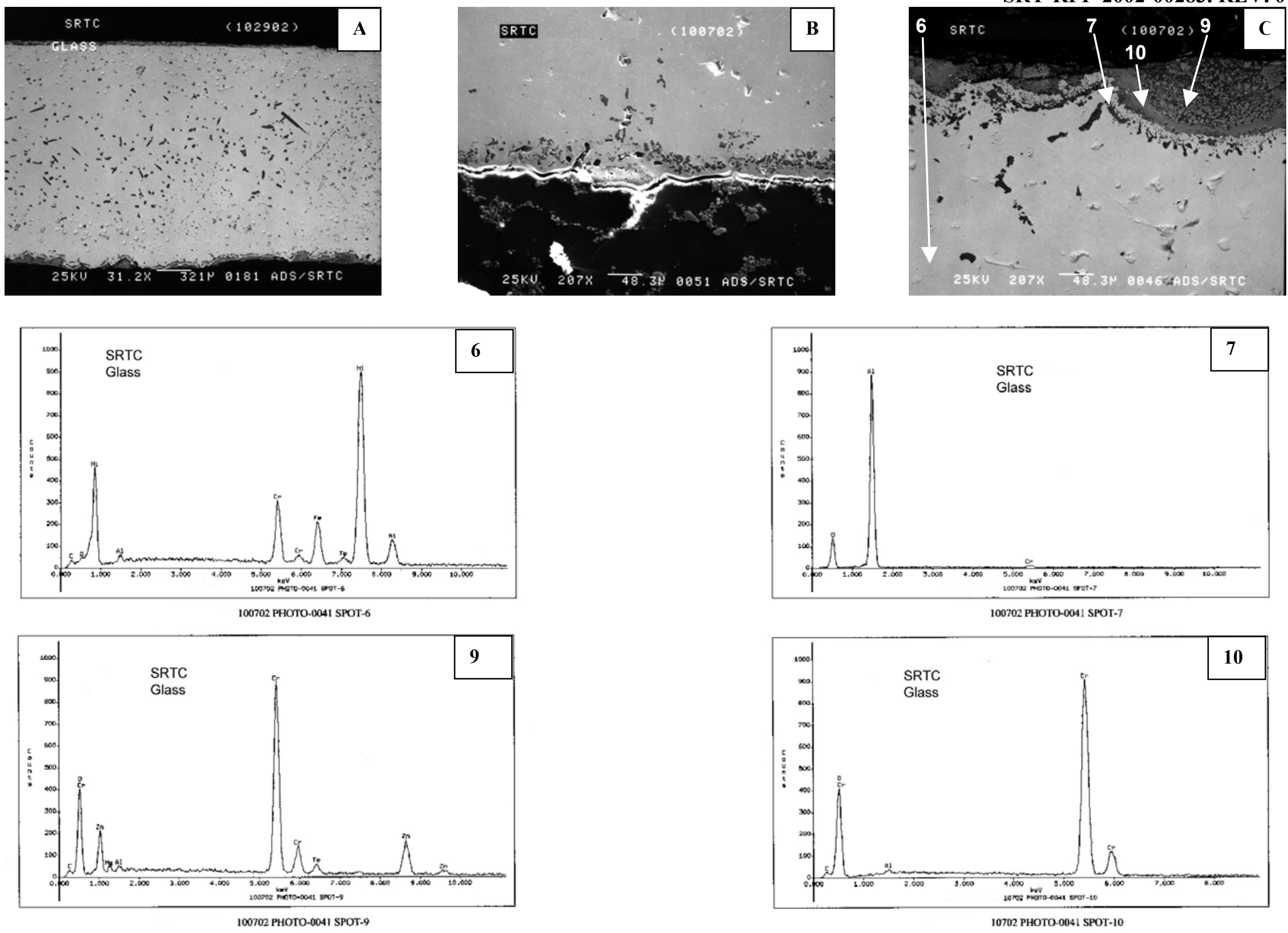

Figure C-5 SEM Photographs and EDS analyses from the glass contact region of the SRTC alloy coupon.

Page A-14 of 54 
WSRC-TR-2002-00588, REV. 0
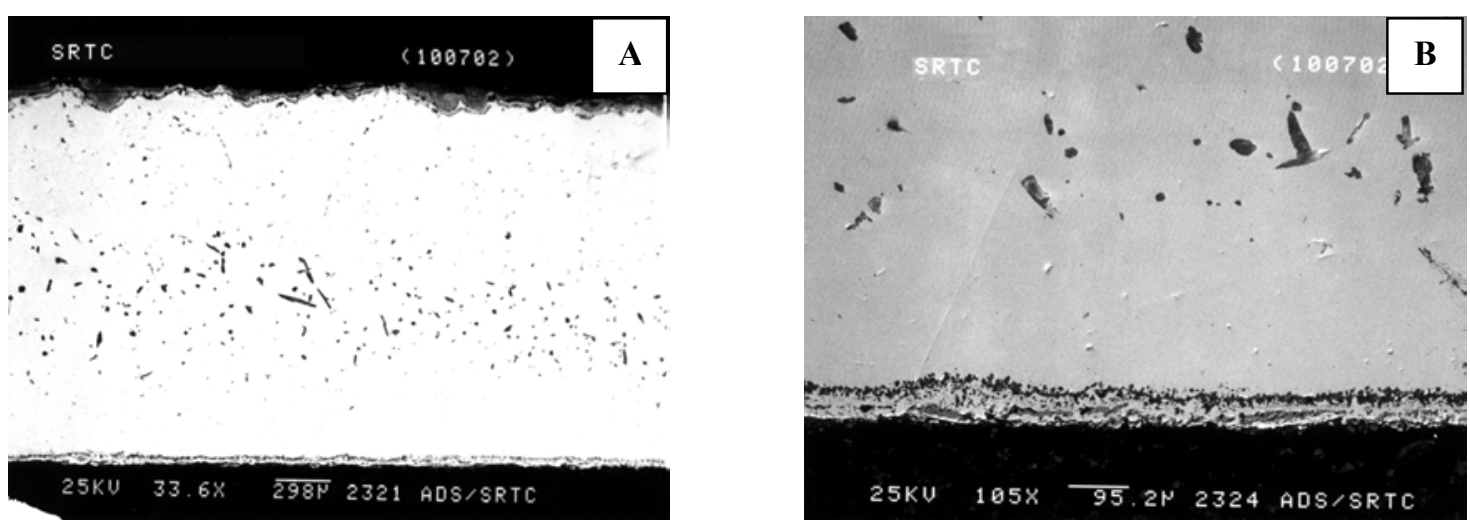

SRT-RPP-2002-00283. REV. 0
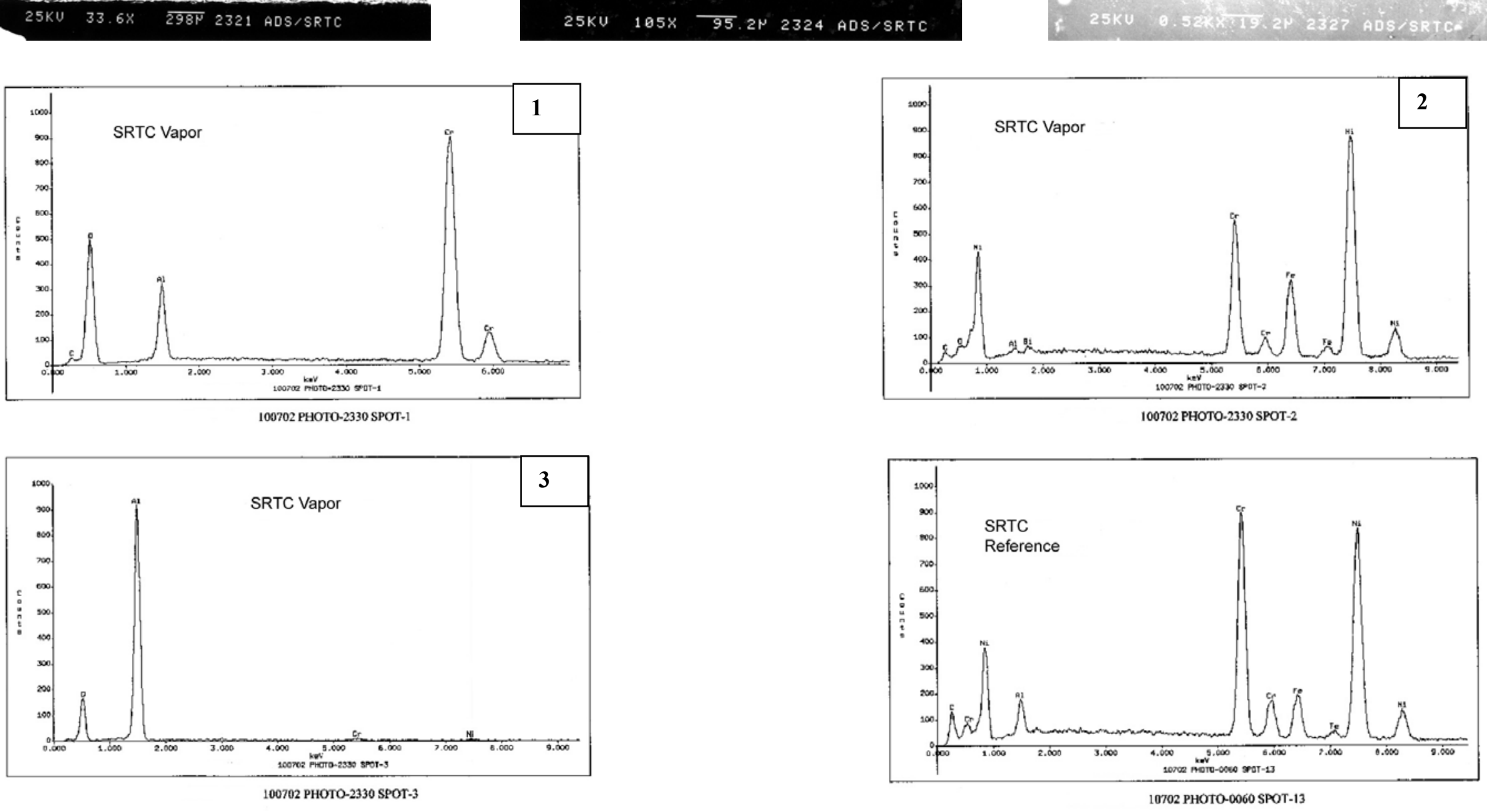

Figure C-6 SEM Photographs and EDS analyses from the vapor space region of the SRTC alloy coupon.

Page A-15 of 54 
WSRC-TR-2002-00588, REV. 0 SRT-RPP-2002-00283. REV. 0
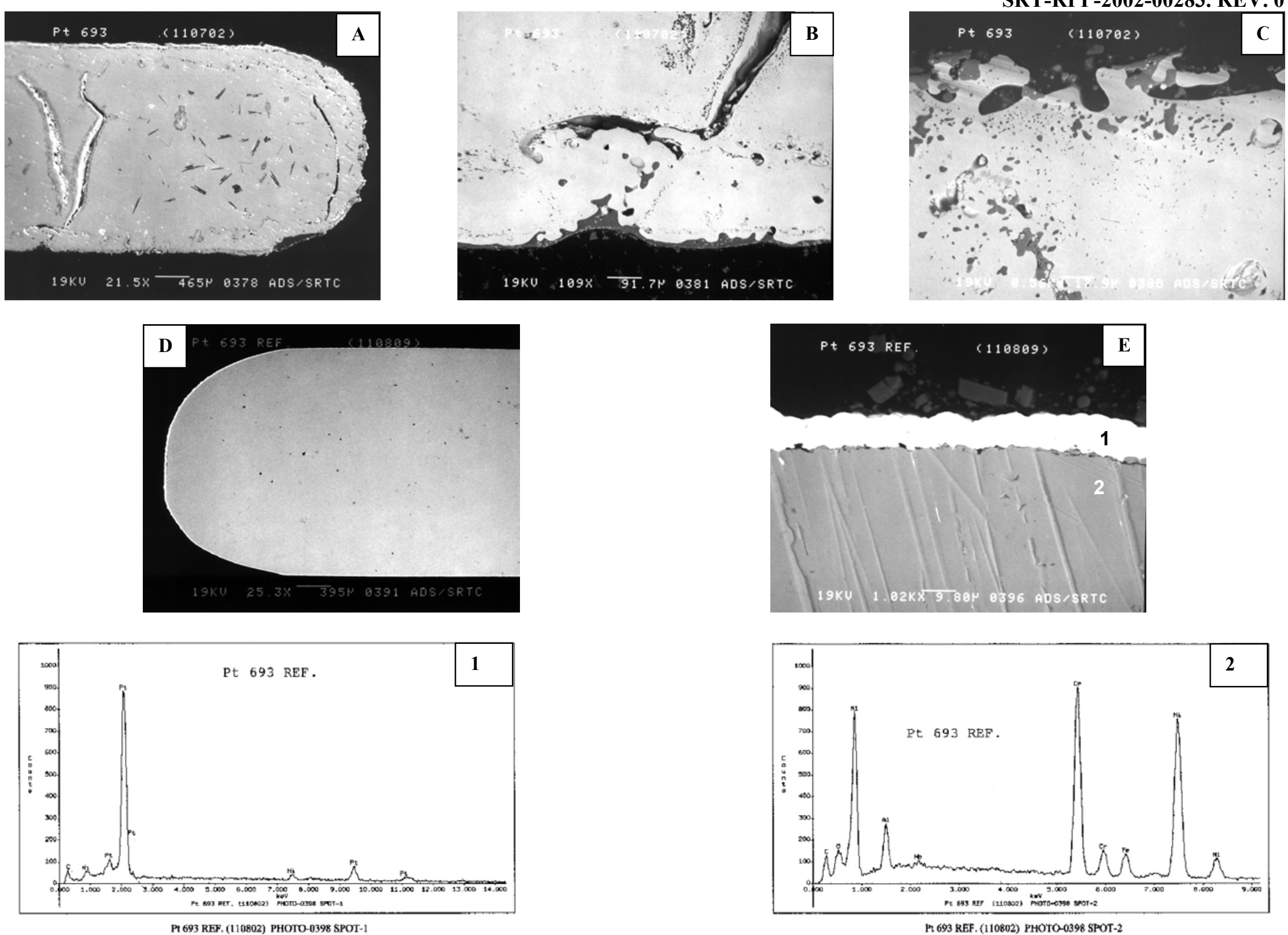

FigureC-7 SEM Photographs of the platinum-coated Inconel 693 coupon from the glass contact region after exposure (A, B and C) and in the as received condition (D and E). Page A-16 of 54 
WSRC-TR-2002-00588, REV. 0

SRT-RPP-2002-00283. REV. 0

\section{APPENDIX D. 20X AND 100X SEM MICROGRAPHS FOR LONG- TERM VAPOR SPACE EXPERIMENT}


WSRC-TR-2002-00588, REV. 0 SRT-RPP-2002-00283. REV. 0

I $693-400 \mathrm{C}-\mathrm{U}-\mathrm{B}$

$25 K U 20.9 \times-479 N \quad 0786$ ADS/SRTC

MA758-400C-U

(112602)

$25 K U 19.9 \times-503 N 0596$ ADS/SRTC

Figure D-1 20X SEM Photos of CouponCross Sections from $400^{\circ} \mathrm{C}$ Zone

Page A-18 of 54

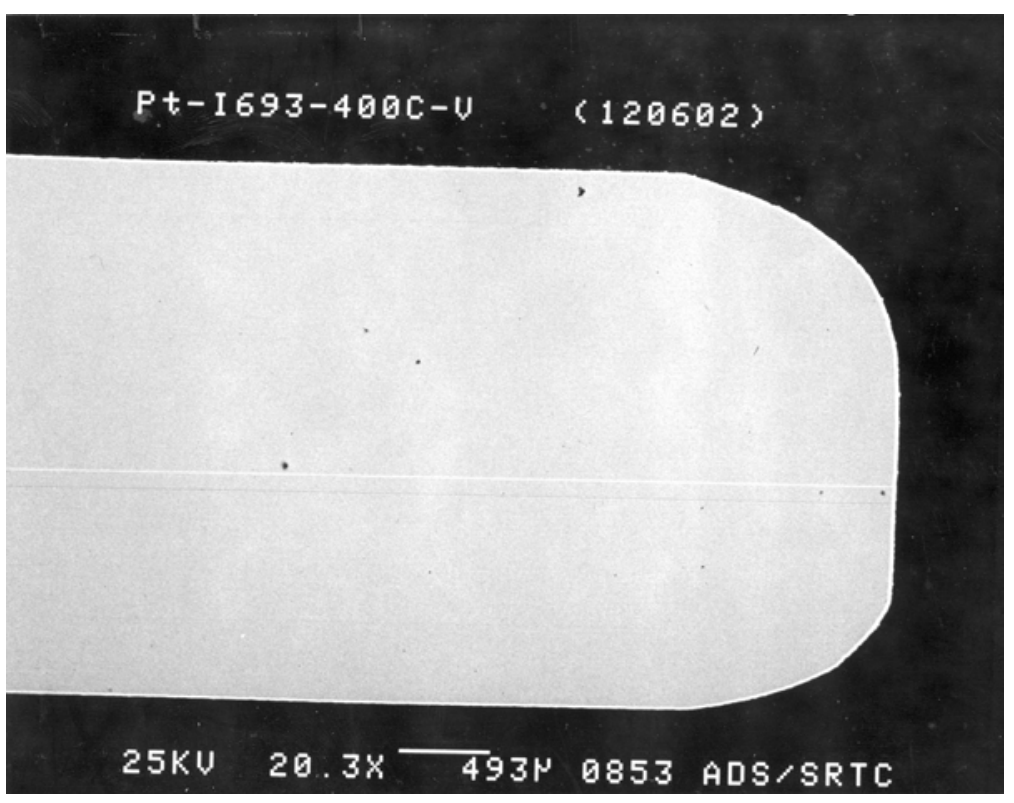

SRTC-400C-U-B (120502)

$25 K U \quad 20.1 \times \overline{498 \mathrm{~N}} 0799$ ADS/SRTC 
WSRC-TR-2002-00588, REV. 0 SRT-RPP-2002-00283. REV. 0

\section{$25 K U 20.7 \times-483 N \quad 0572$ ADS/SRTC}

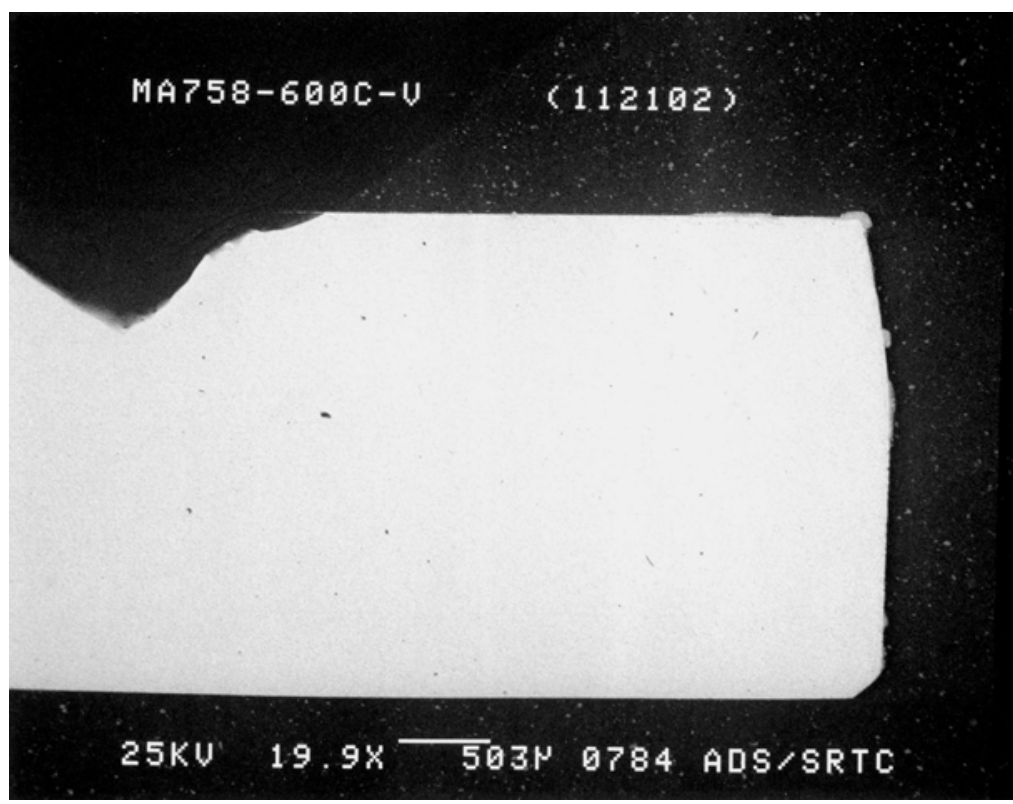

$P t-I 693-600 \mathrm{C}-\mathrm{V}$

(112602)
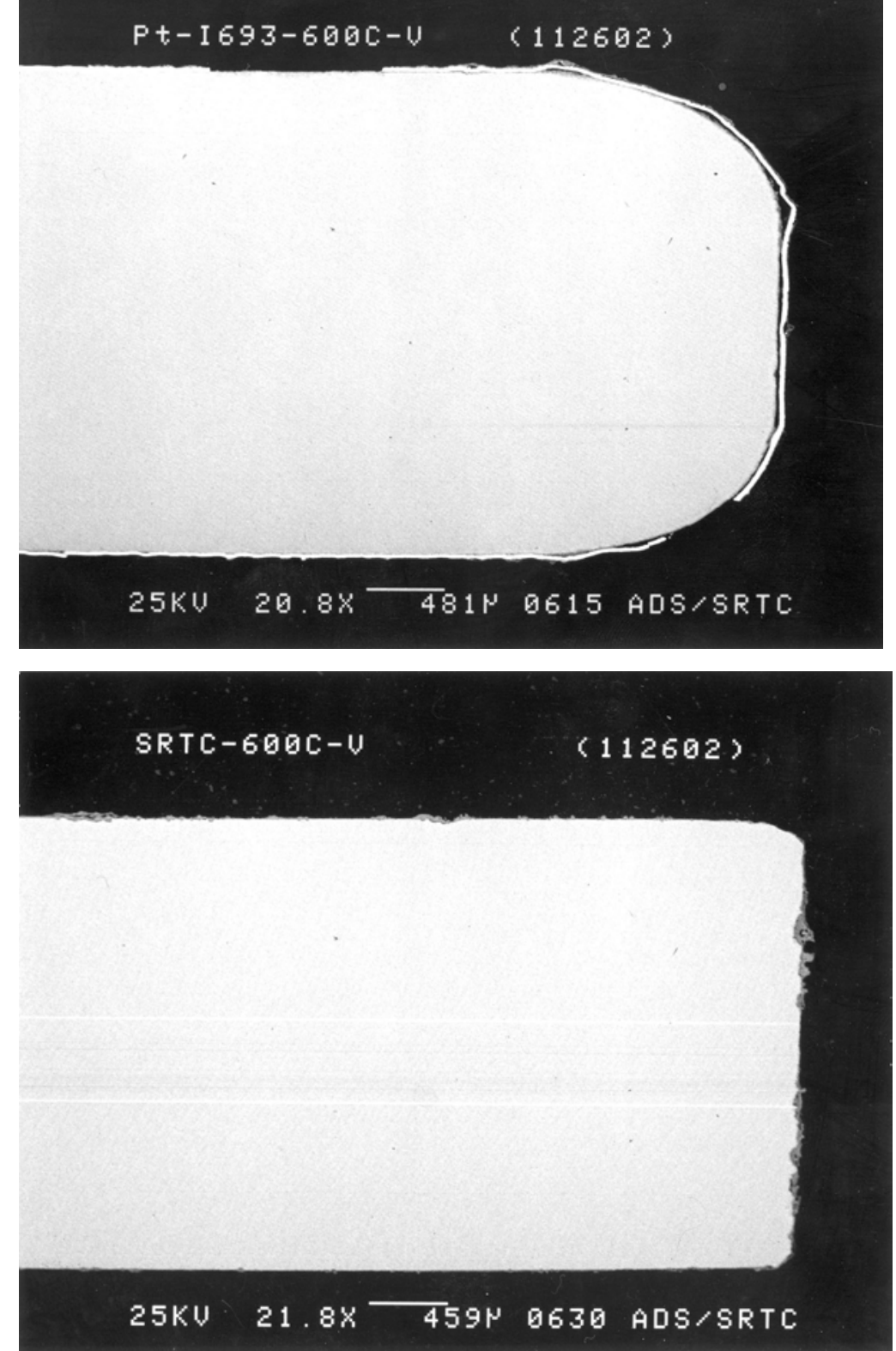

Figure D-2 20X SEM Photos of CouponCross Sections from $600^{\circ} \mathrm{C}$ Zone 
WSRC-TR-2002-00588, REV. 0
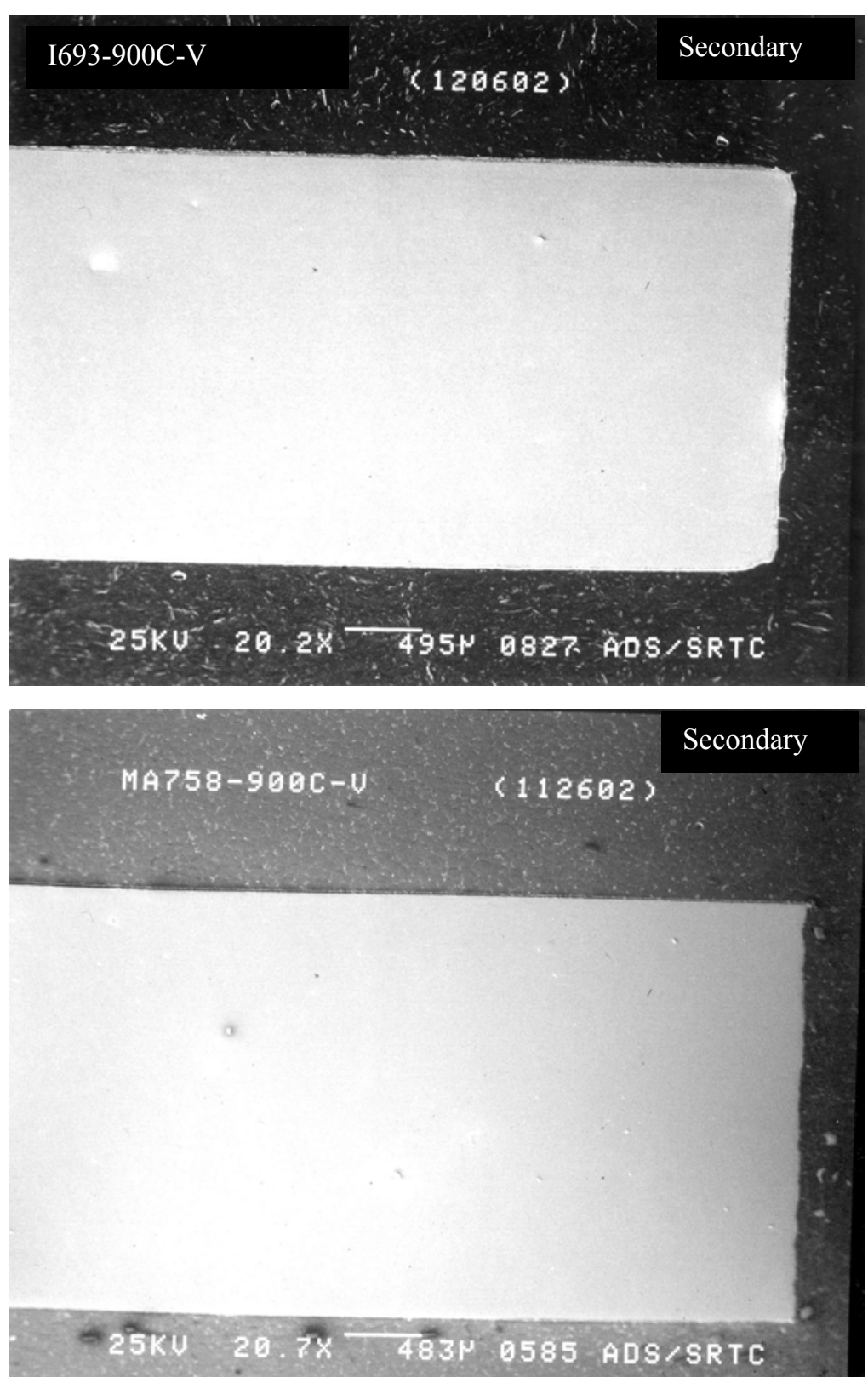

Figure D-3 20X SEM Photos of CouponCross Sections from $900^{\circ} \mathrm{C}$ Zone

Page A-20 of 54 SRT-RPP-2002-00283. REV. 0
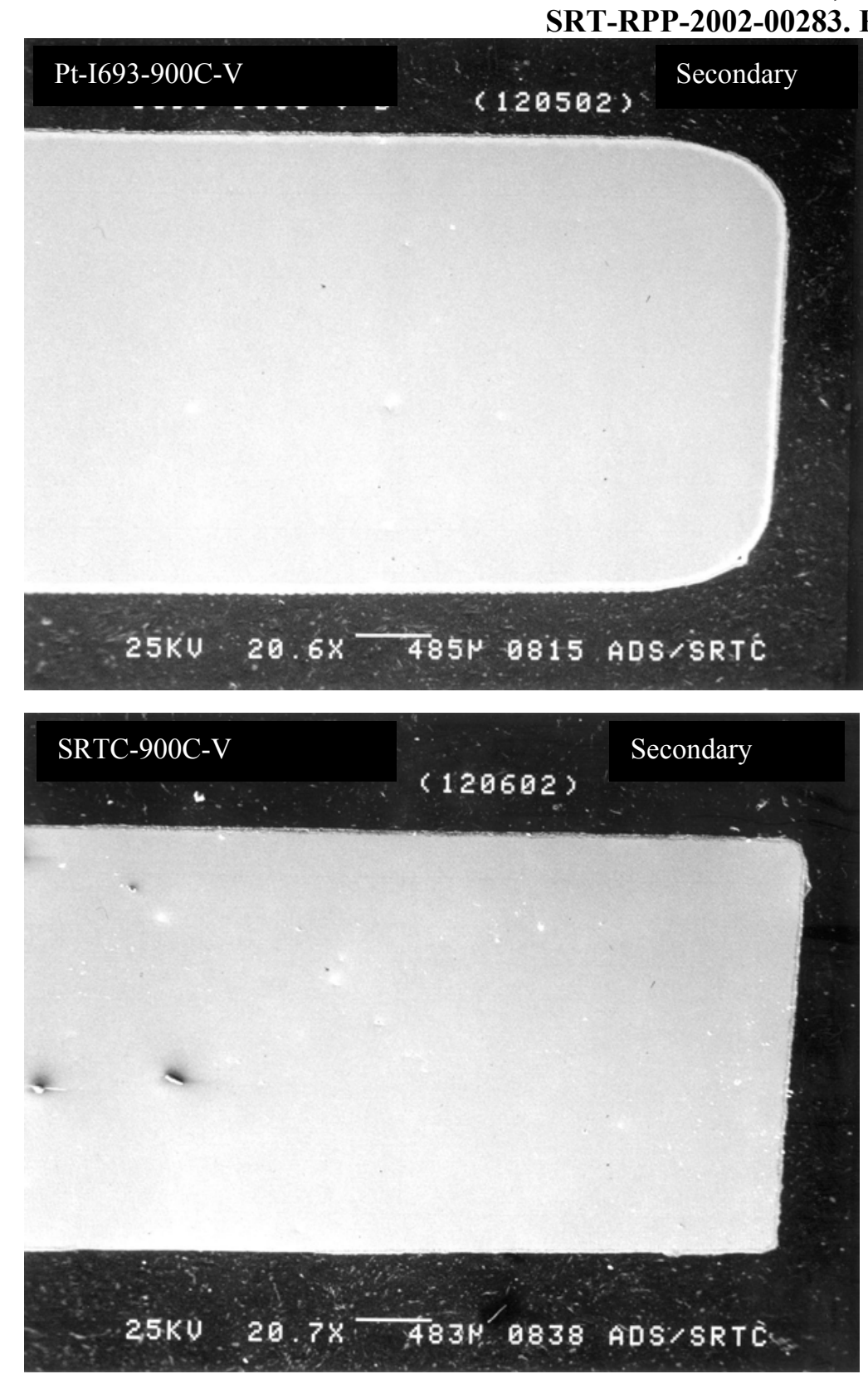
WSRC-TR-2002-00588, REV. 0 SRT-RPP-2002-00283. REV. 0
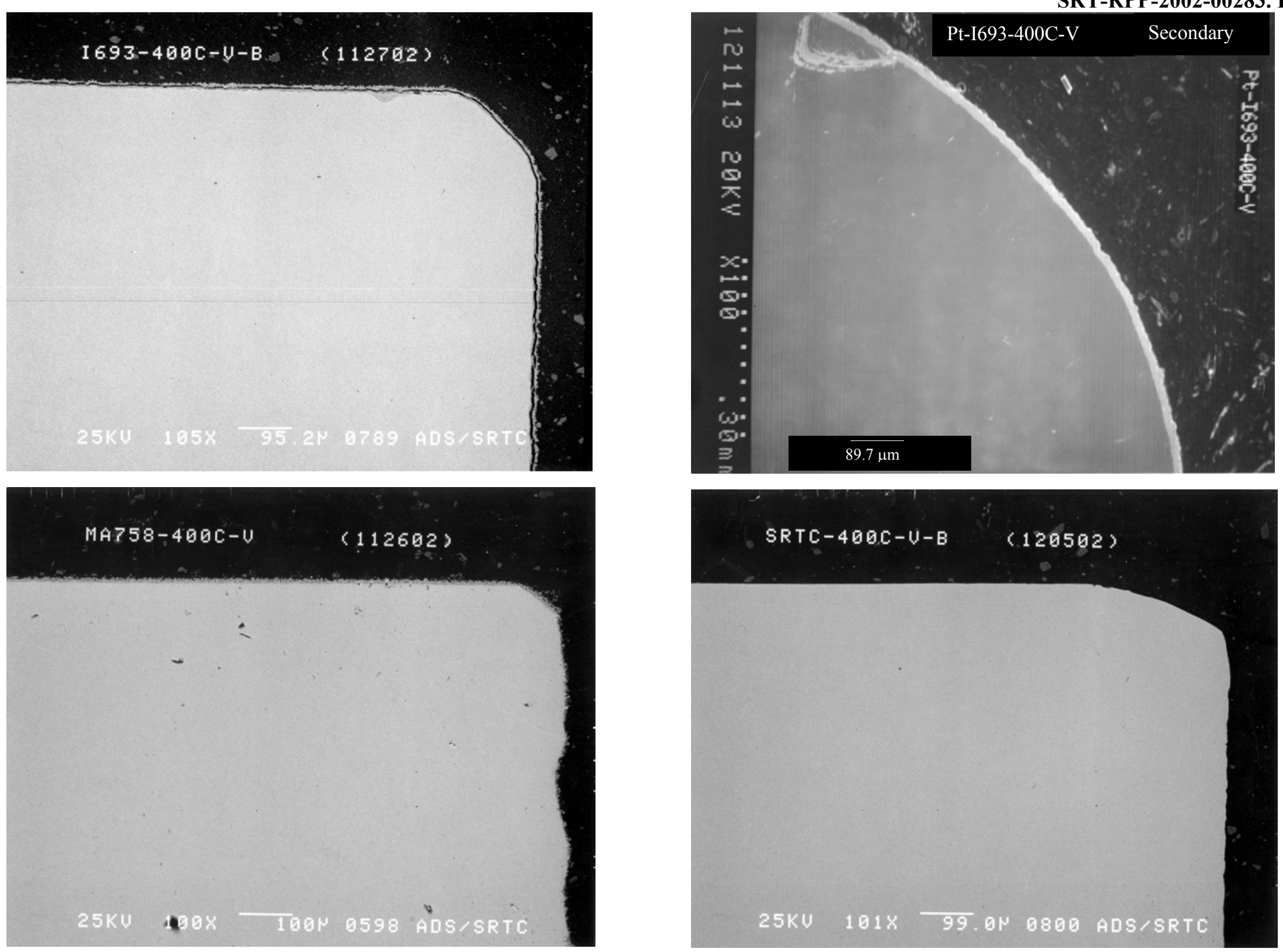

Figure D-4 100X SEM Photos of CouponCross Sections from $400^{\circ} \mathrm{C}$ Zone 
WSRC-TR-2002-00588, REV. 0 SRT-RPP-2002-00283. REV. 0
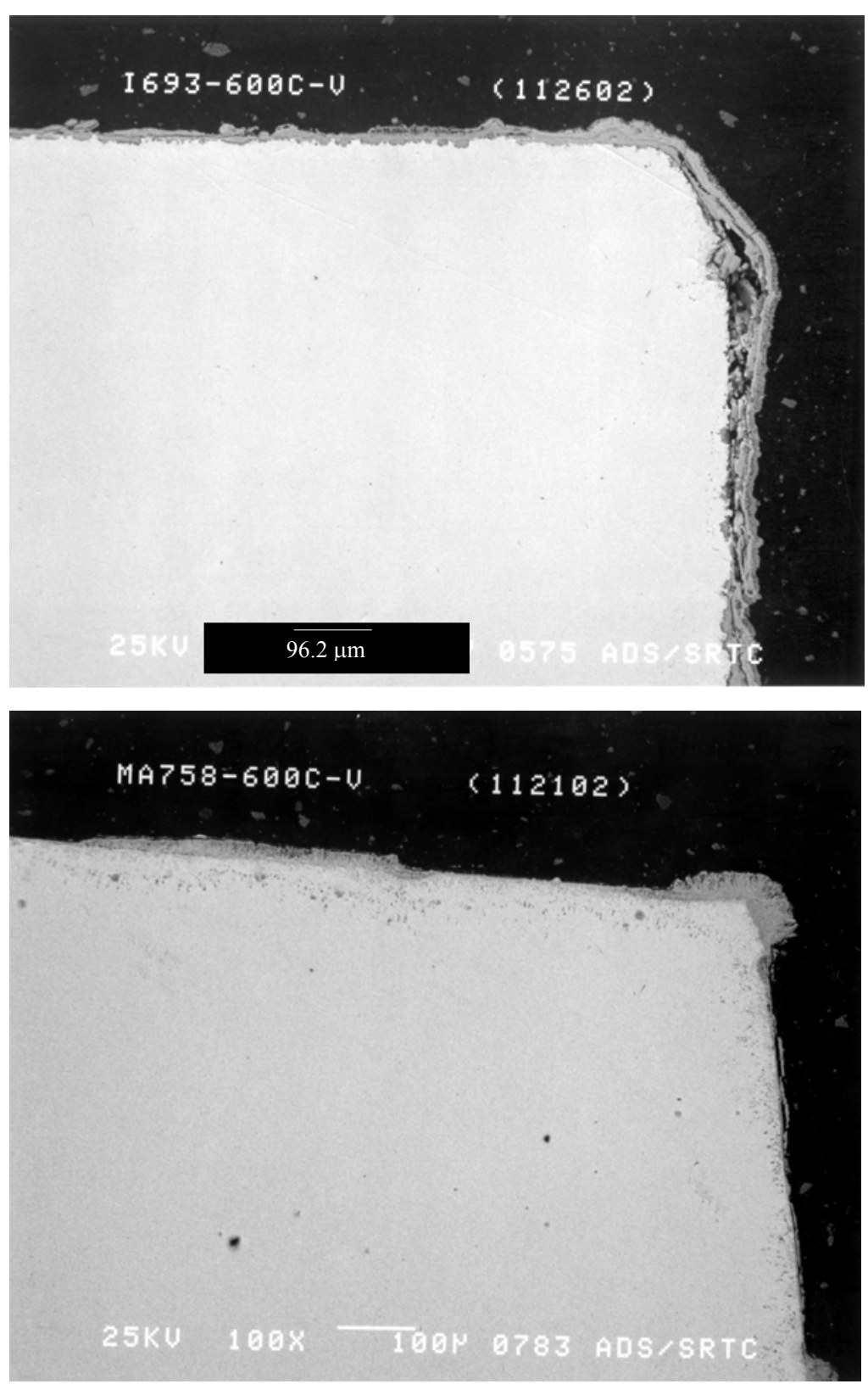
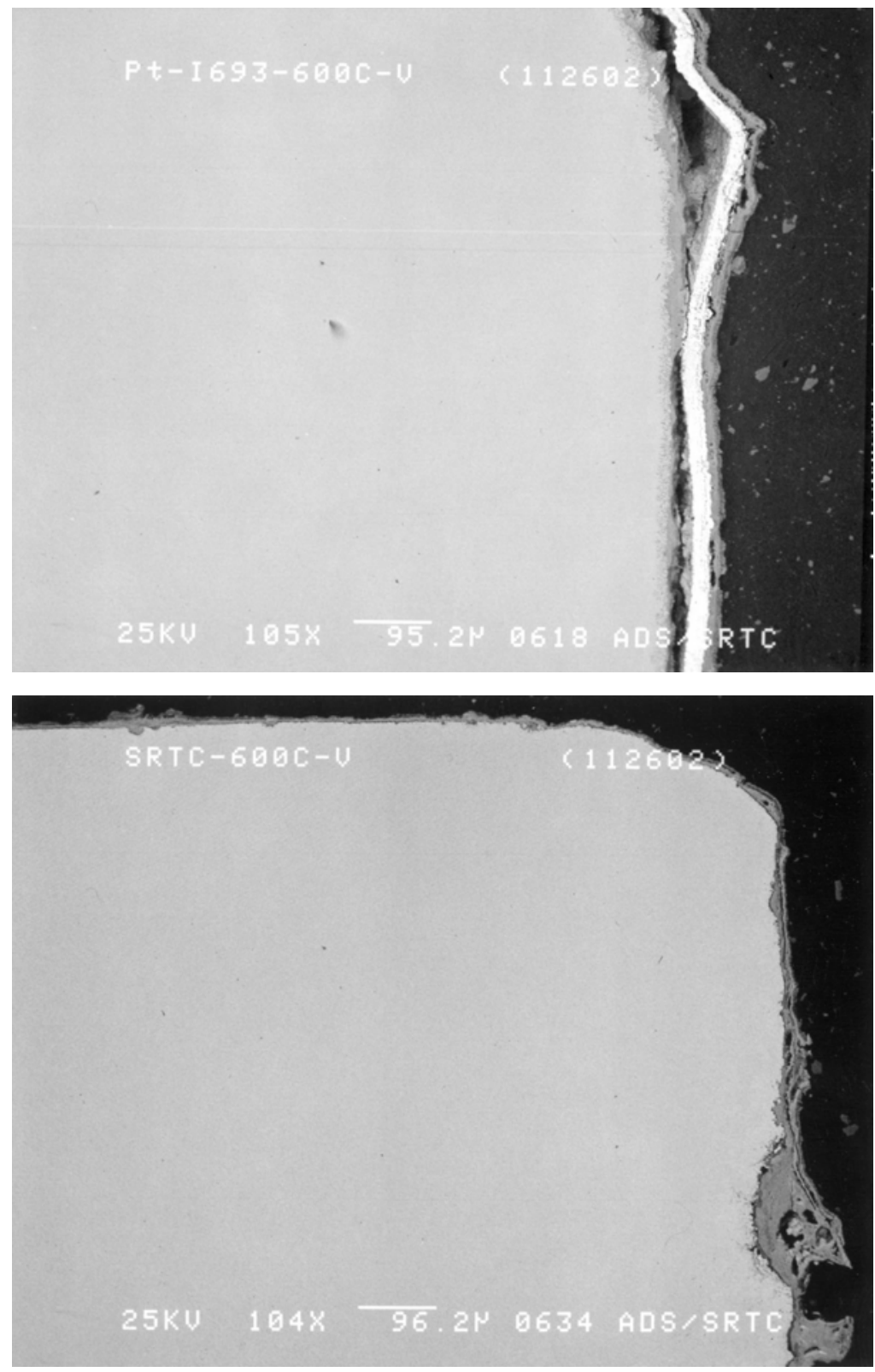

Figure D-5 100X SEM Photos of CouponCross Sections from $600^{\circ} \mathrm{C}$ Zone

Page A-22 of 54 
WSRC-TR-2002-00588, REV. 0
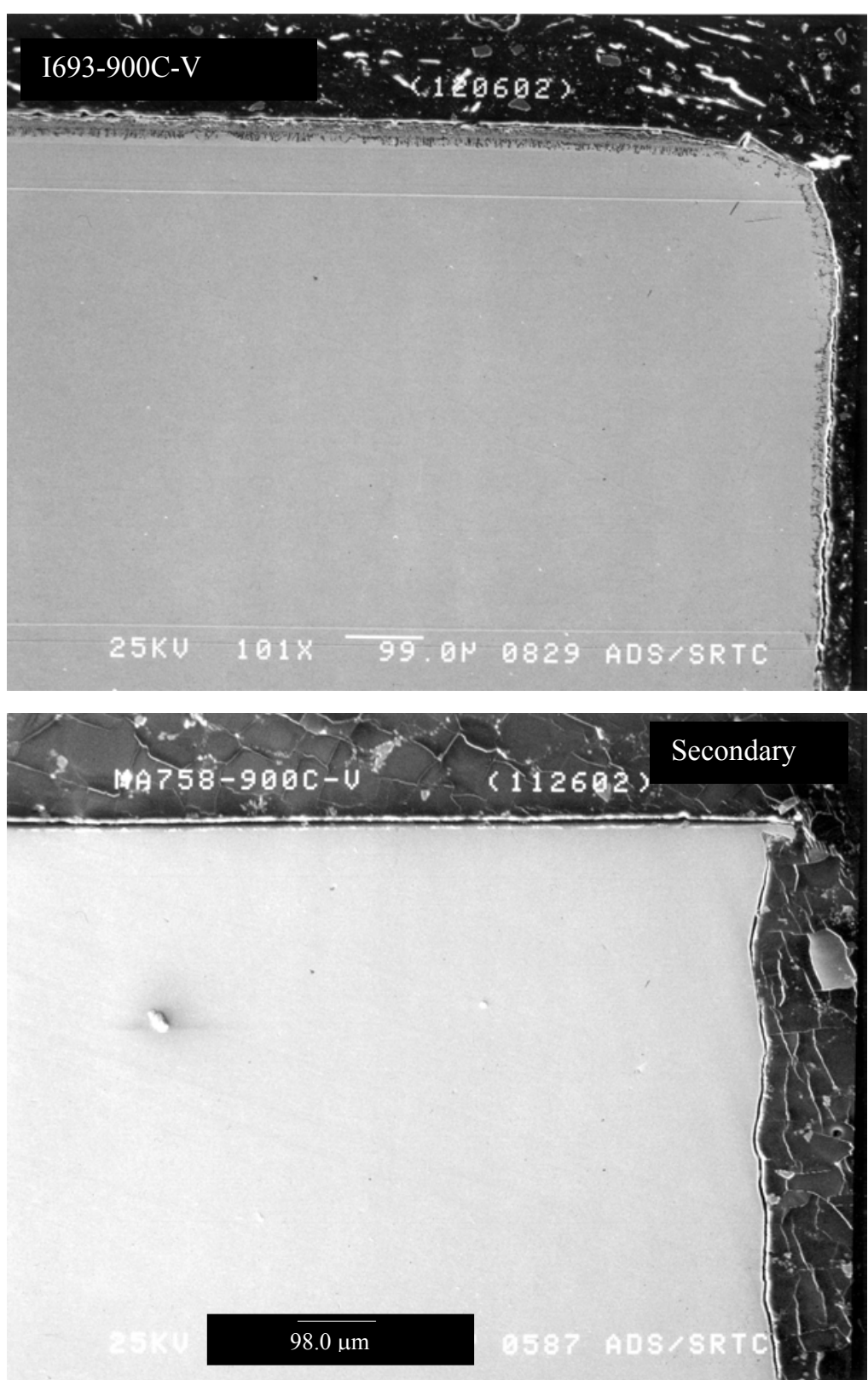

SRT-RPP-2002-00283. REV. 0
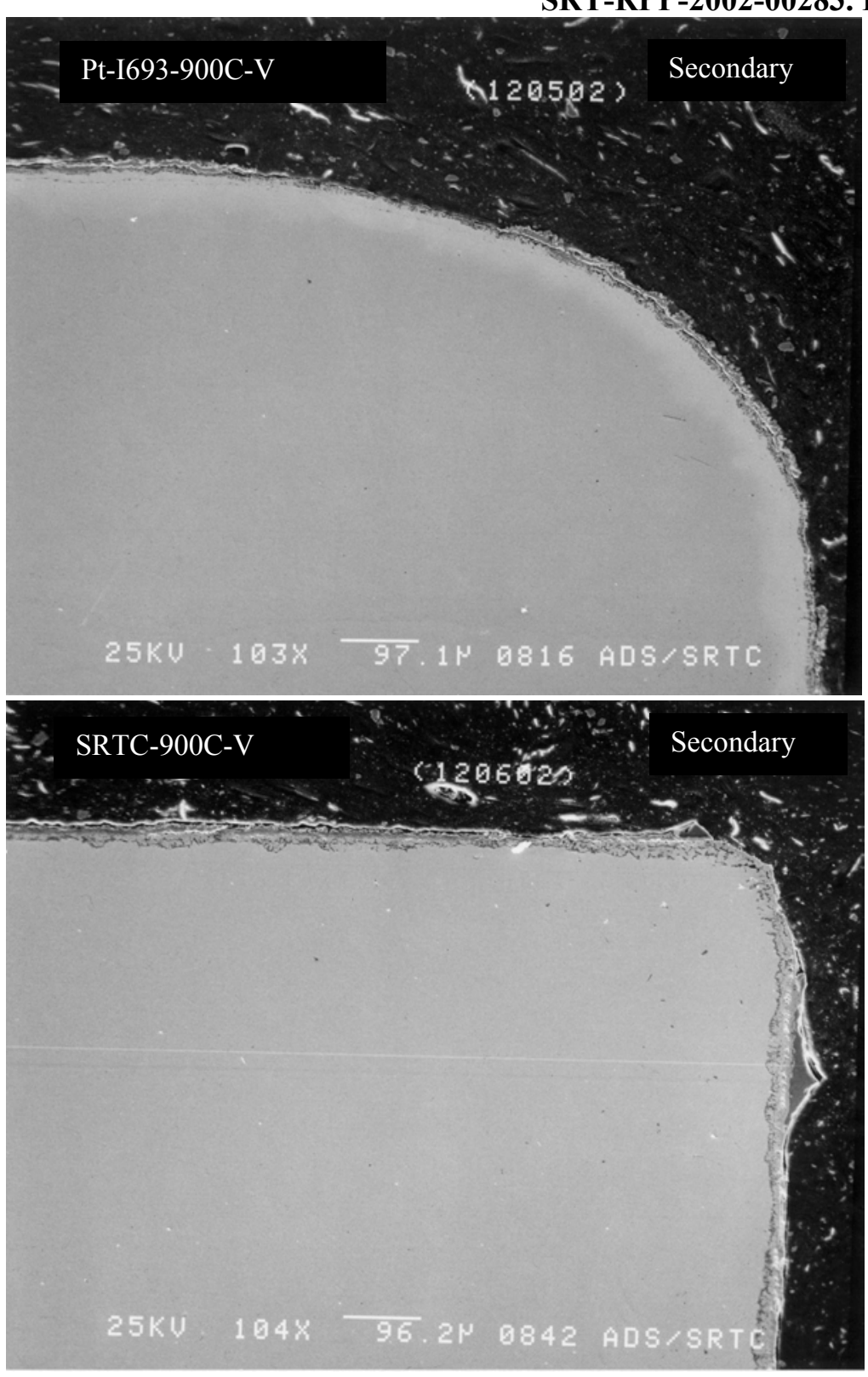

Figure D-6 100X SEM Photos of CouponCross Sections from $900^{\circ} \mathrm{C}$ Zone 
WSRC-TR-2002-00588, REV. 0

SRT-RPP-2002-00283. REV. 0

\section{APPENDIX E. $400^{\circ} \mathrm{C}$ SEM MICROGRAPHS FOR LONG-TERM VAPOR SPACE EXPERIMENT}

Page A-24 of 54 
WSRC-TR-2002-00588, REV. 0 SRT-RPP-2002-00283. REV. 0
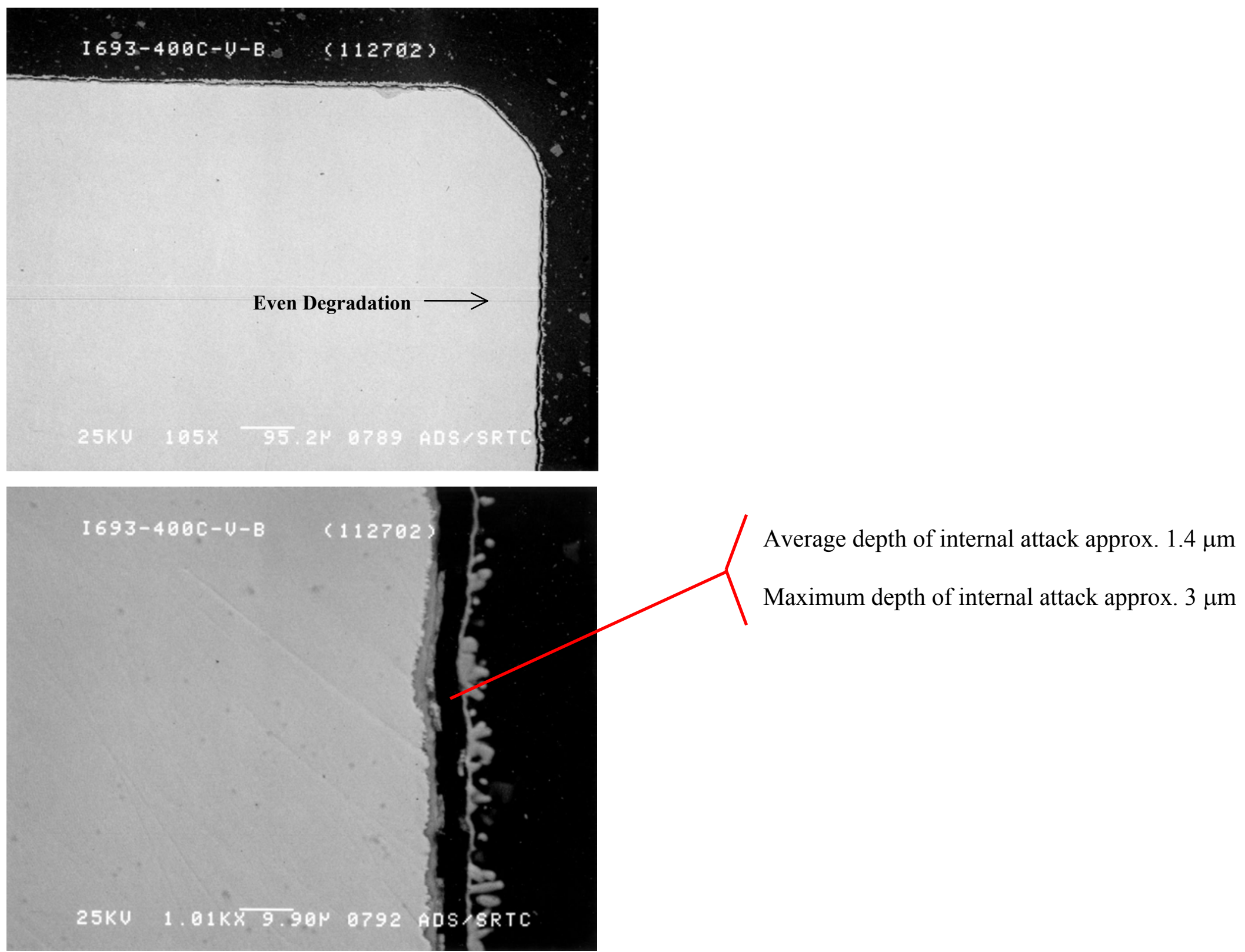

Figure E-1 SEMPhotos Showing Depth of Attack, I-693 at $400^{\circ} \mathrm{C}$ 
WSRC-TR-2002-00588, REV. 0 SRT-RPP-2002-00283. REV. 0
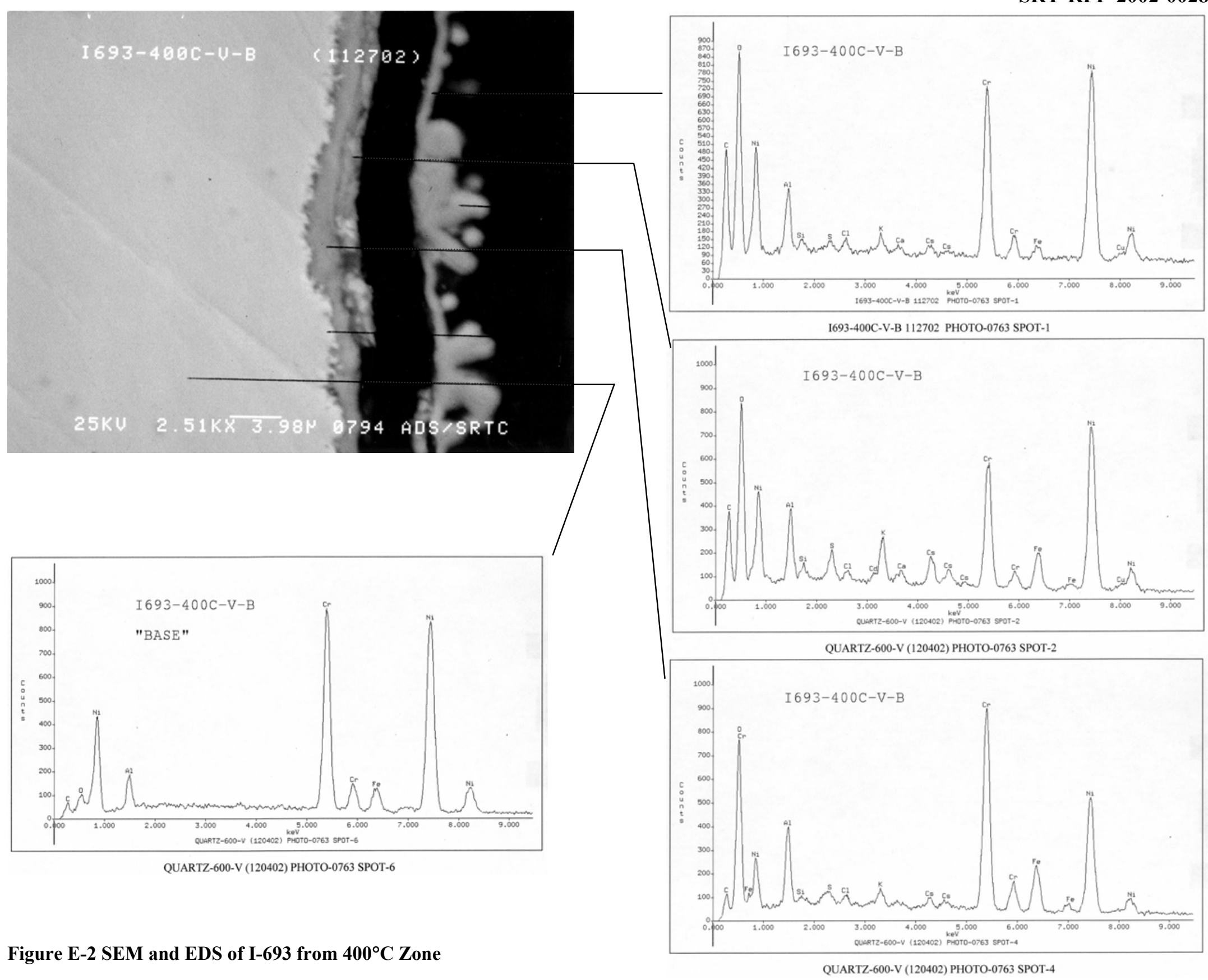

Figure E-2 SEM and EDS of I-693 from $400^{\circ} \mathrm{C}$ Zone

Page A-26 of 54 
WSRC-TR-2002-00588, REV. 0 SRT-RPP-2002-00283. REV. 0
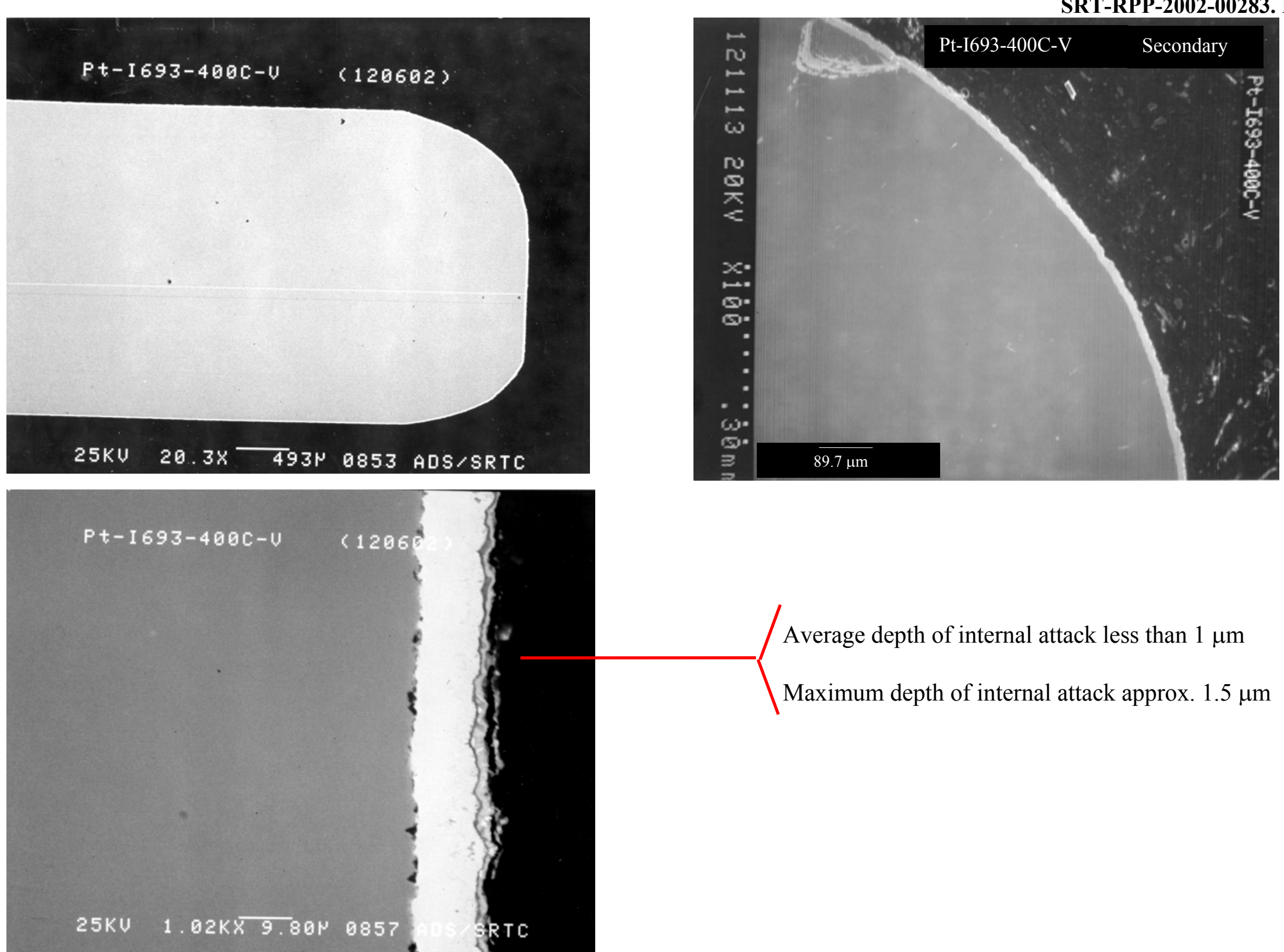

Figure E-3 SEMPhotos Showing Depth of Attack, Pt-Coated I-693 at $400^{\circ} \mathrm{C}$ 
WSRC-TR-2002-00588, REV. 0 SRT-RPP-2002-00283. REV. 0

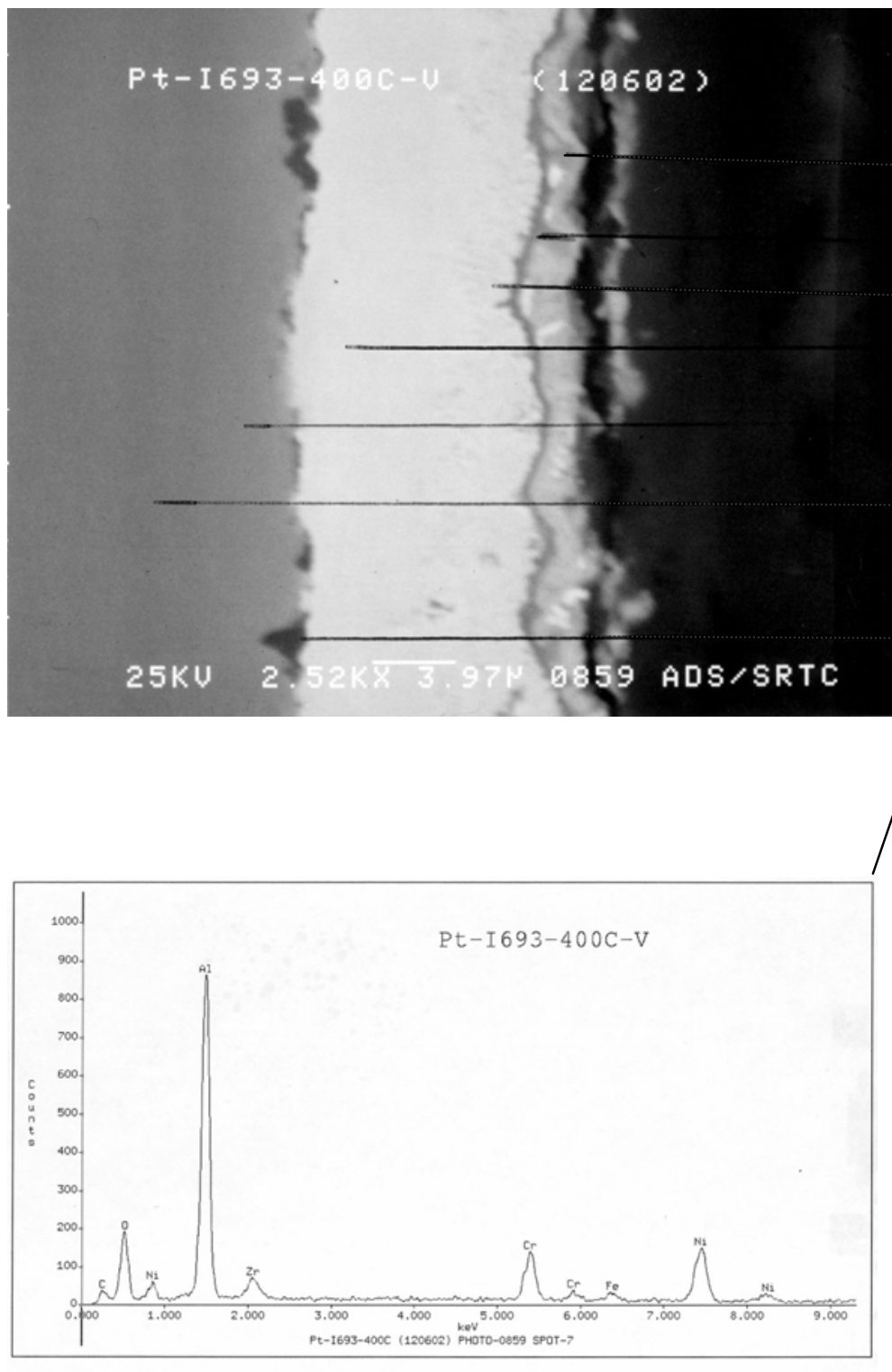

Pt-1693-400C (120602) PHOTO-0859 SPOT-7

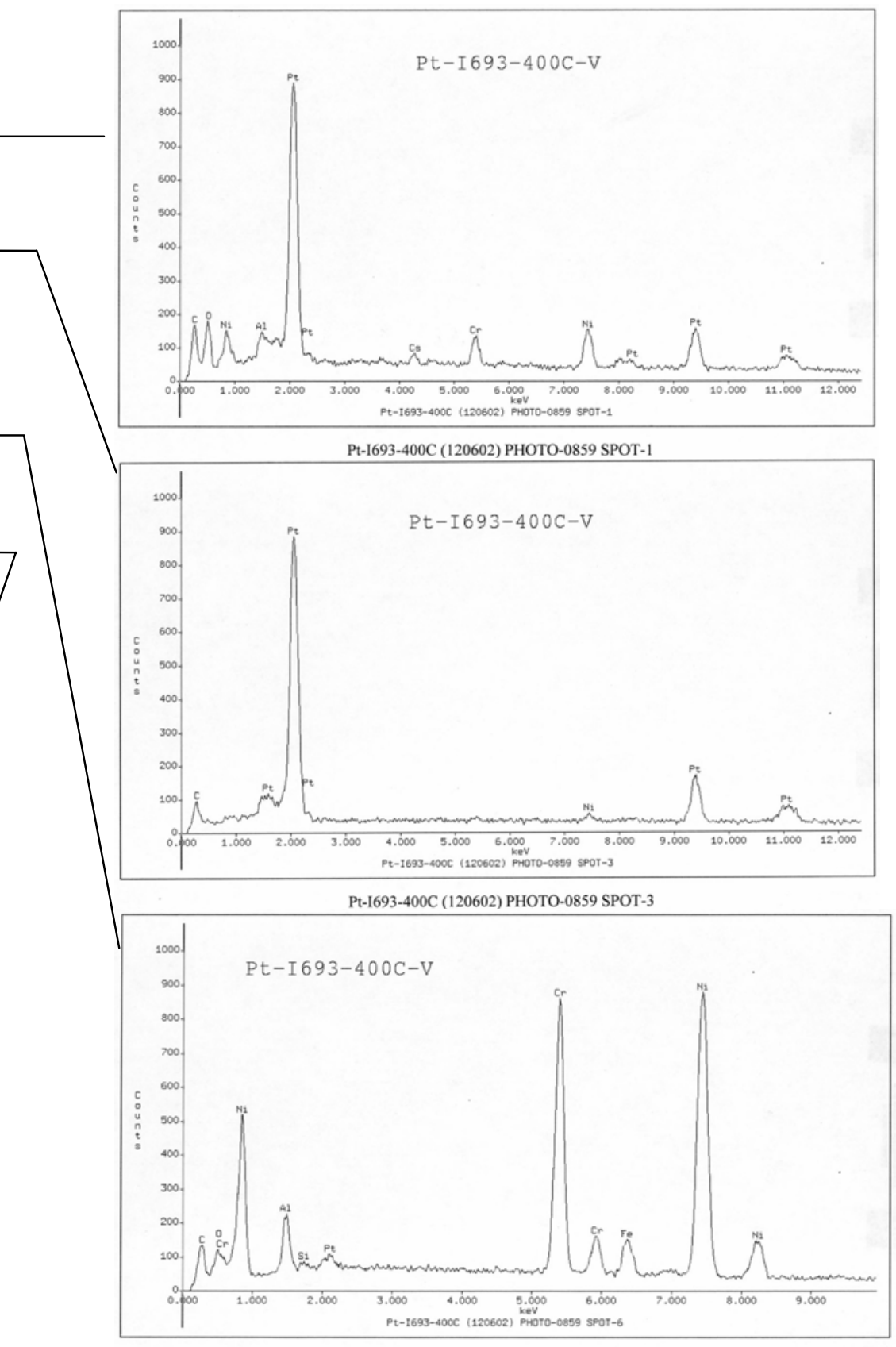

Pt-1693-400C (120602) PHOTO-0859 SPOT-6 
WSRC-TR-2002-00588, REV. 0 SRT-RPP-2002-00283. REV. 0
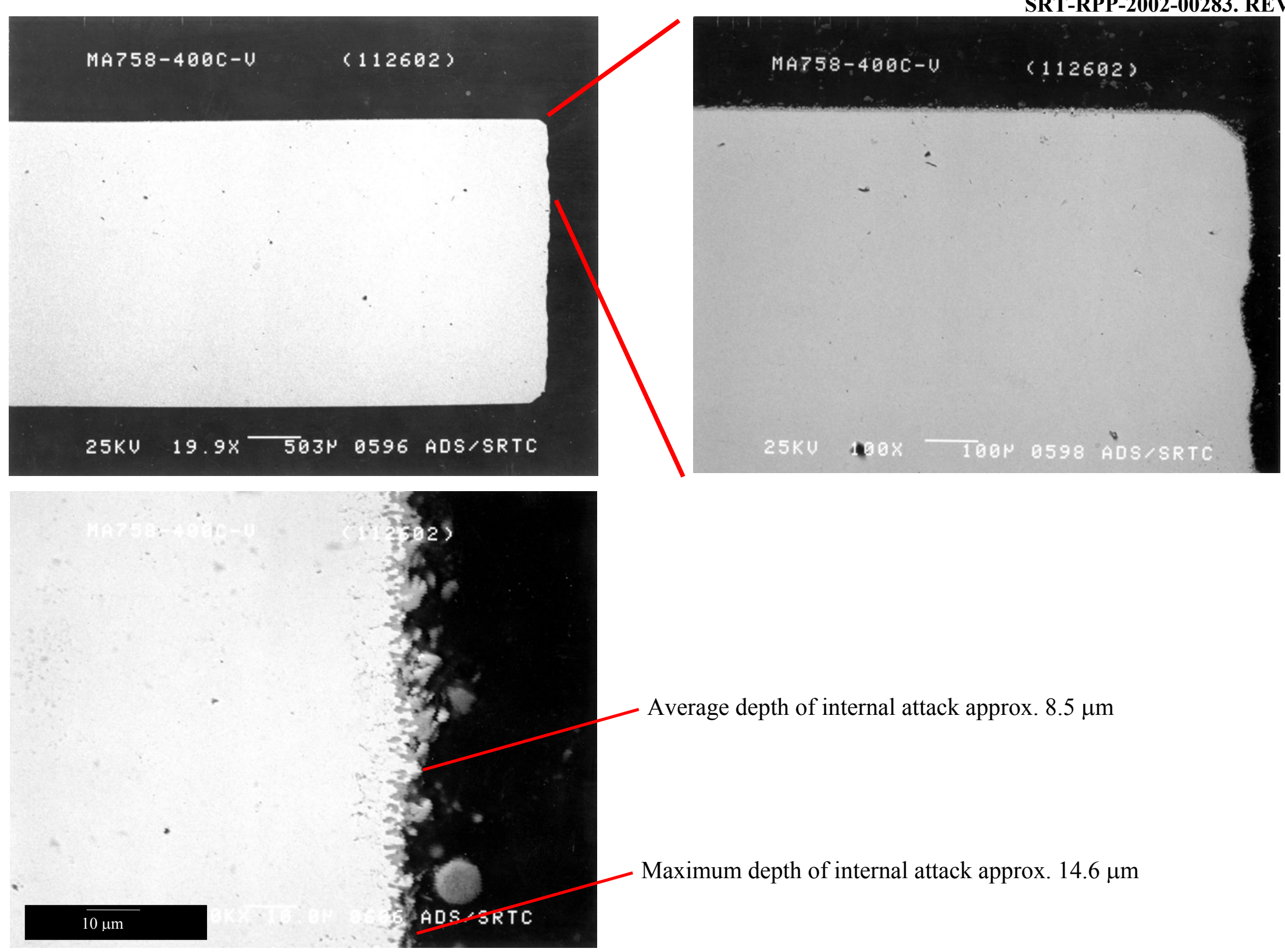

Figure E-5 SEM Photos Showing Depth of Attack, MA 758 at $400^{\circ} \mathrm{C}$ 
WSRC-TR-2002-00588, REV. 0 SRT-RPP-2002-00283. REV. 0

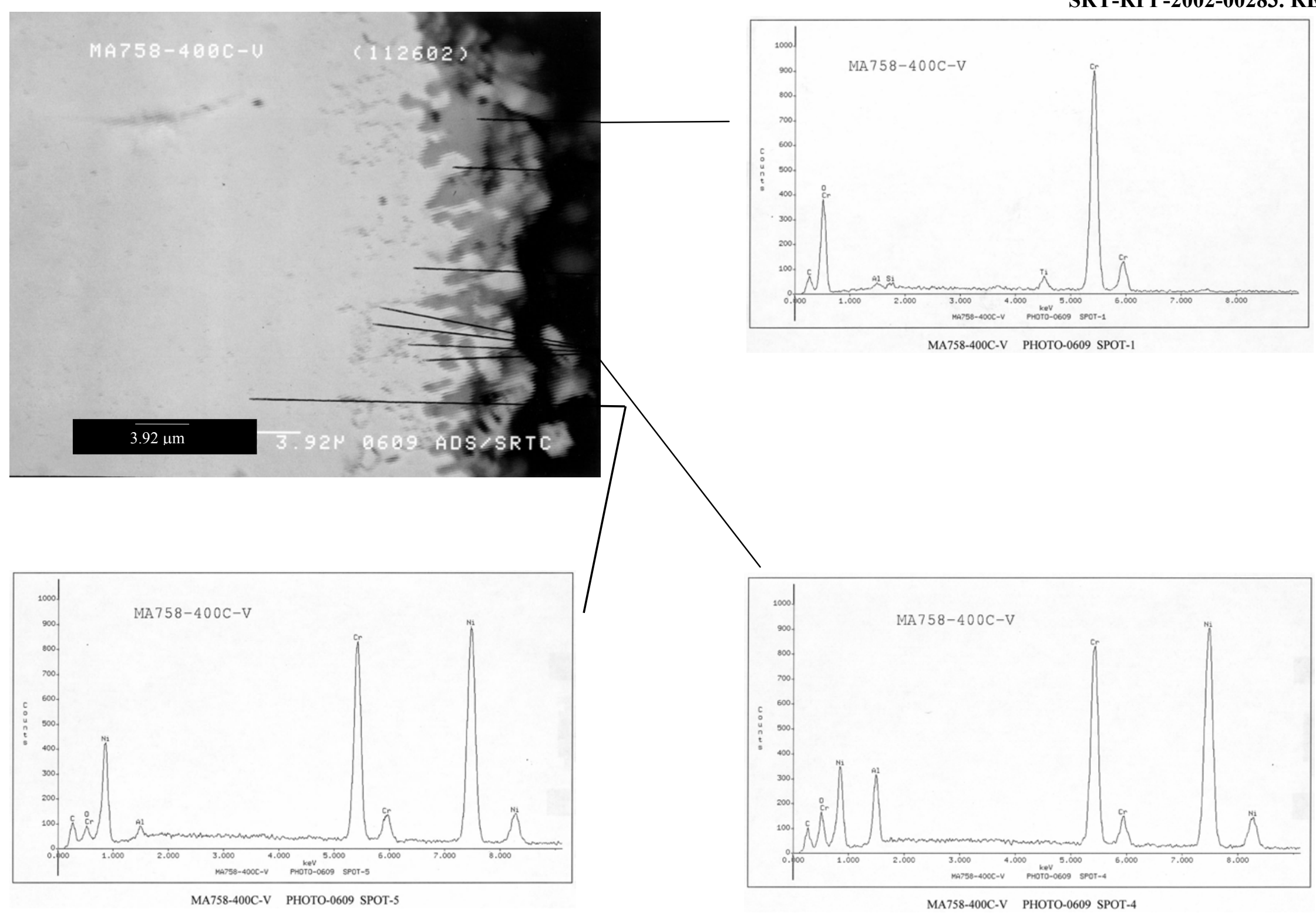

Figure E-6 SEM and EDS of MA 758 from $400^{\circ} \mathrm{C}$ Zone

Page A-30 of 54 
WSRC-TR-2002-00588, REV. 0 SRT-RPP-2002-00283. REV. 0

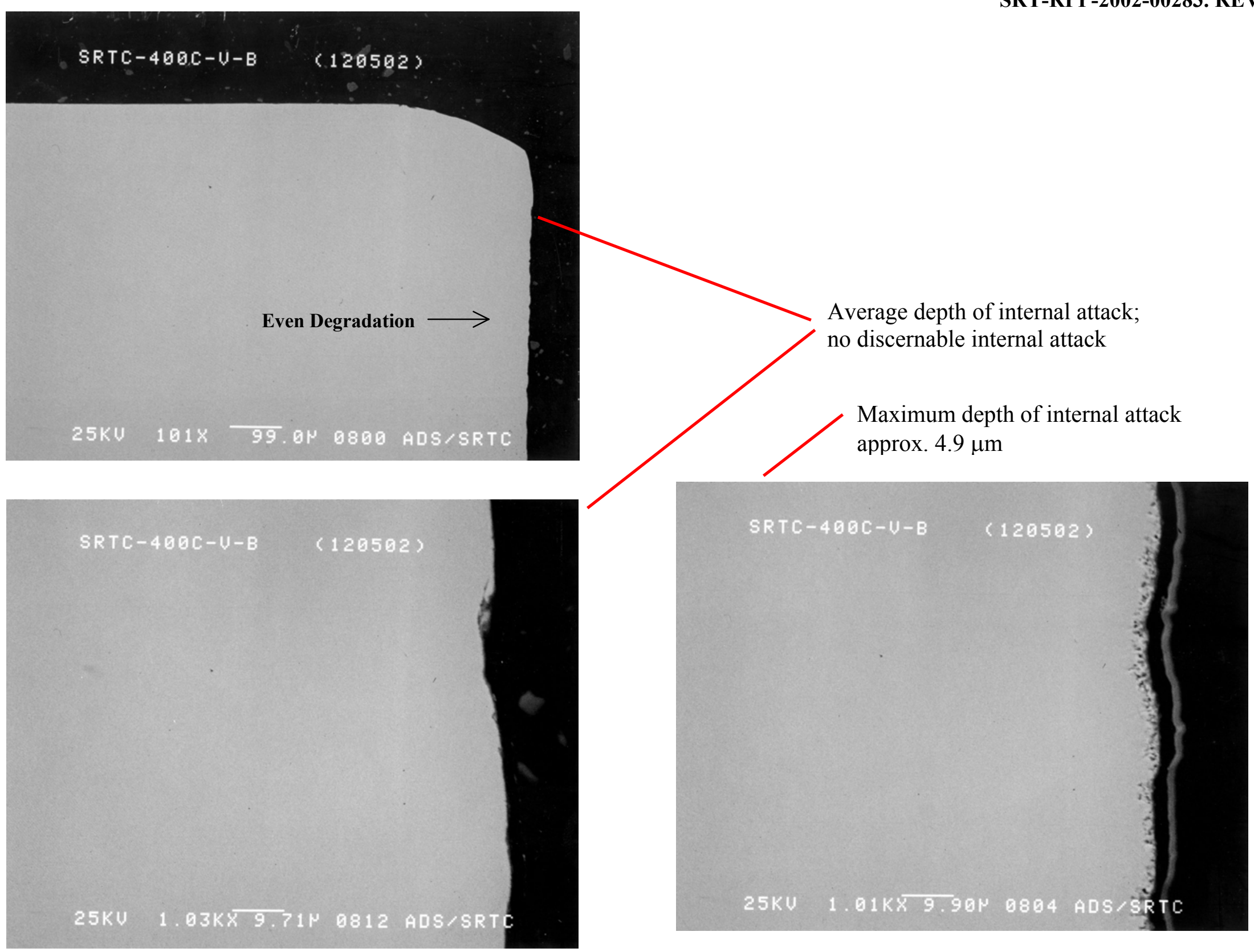


WSRC-TR-2002-00588, REV. 0 SRT-RPP-2002-00283. REV. 0

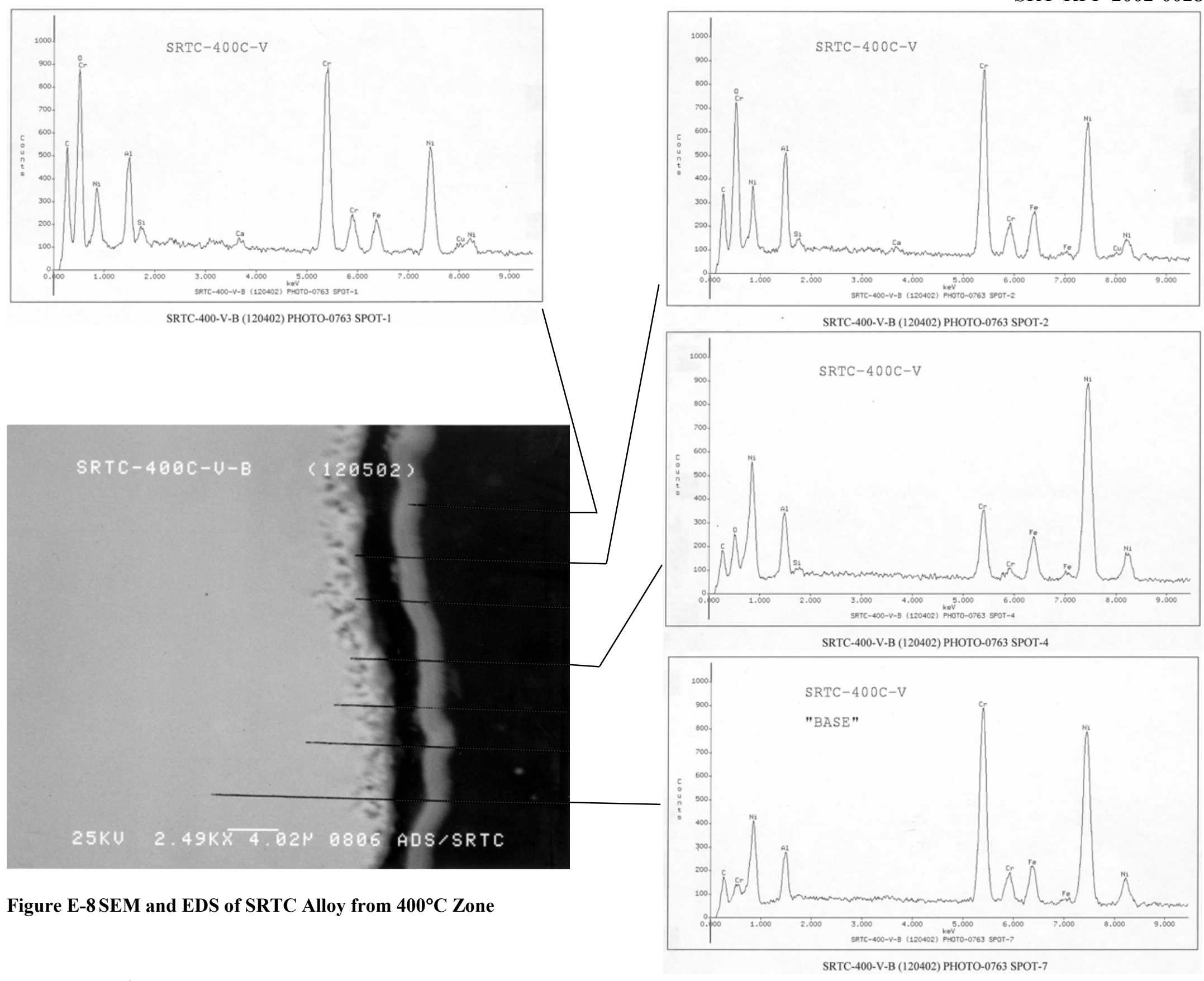

Page A-32 of 54 
WSRC-TR-2002-00588, REV. 0

SRT-RPP-2002-00283. REV. 0

\section{APPENDIX F. $600^{\circ} \mathrm{C}$ SEM MICROGRAPHS FOR LONG-TERM VAPOR SPACE EXPERIMENT}


WSRC-TR-2002-00588, REV. 0 SRT-RPP-2002-00283. REV. 0
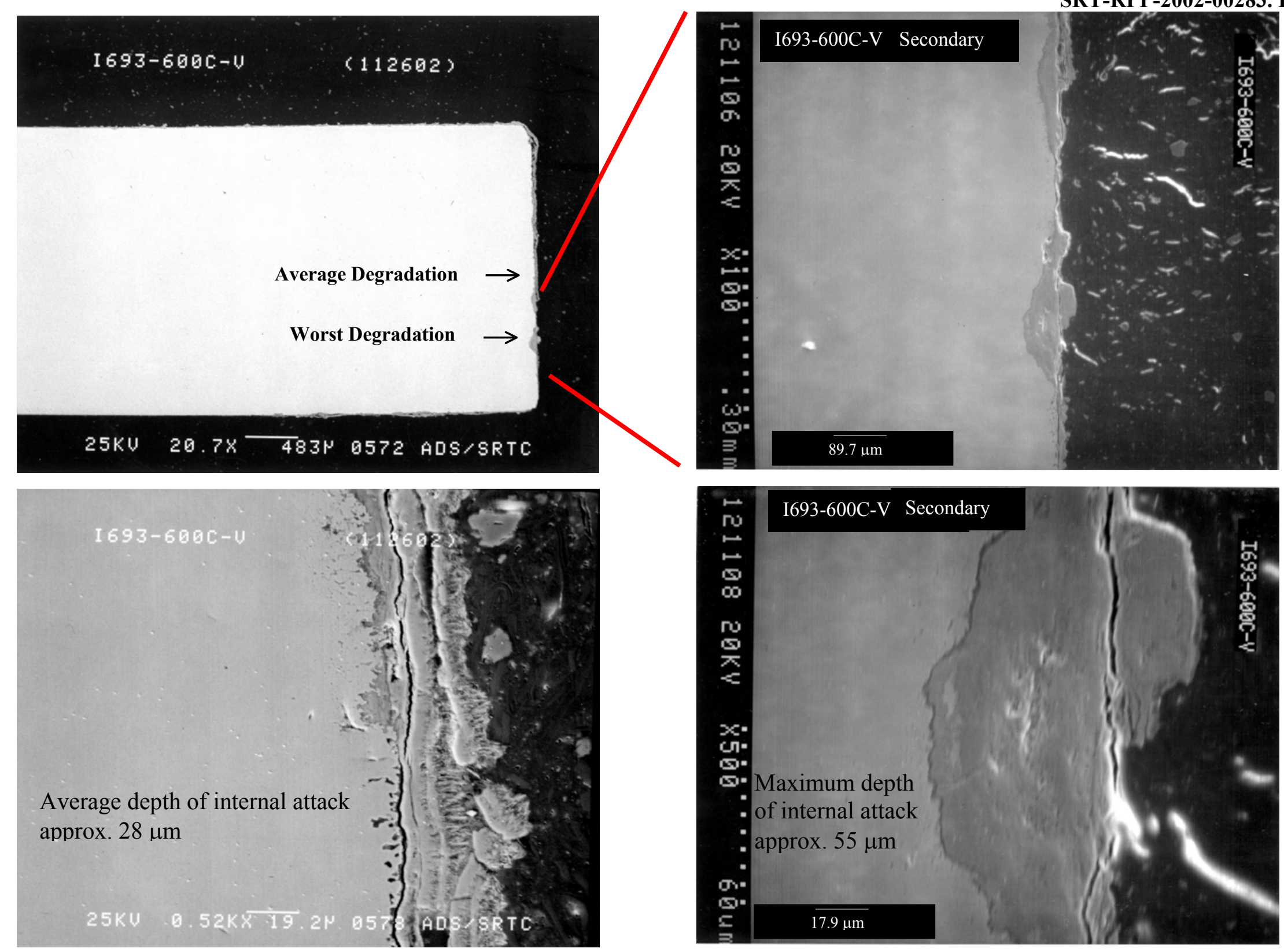

Figure F-1 SEMPhotos Showing Depth of Attack, I-693 at $600^{\circ} \mathrm{C}$

Page 34 of 54 
WSRC-TR-2002-00588, REV . 0 SRT-RPP-2002-00283. REV. 0
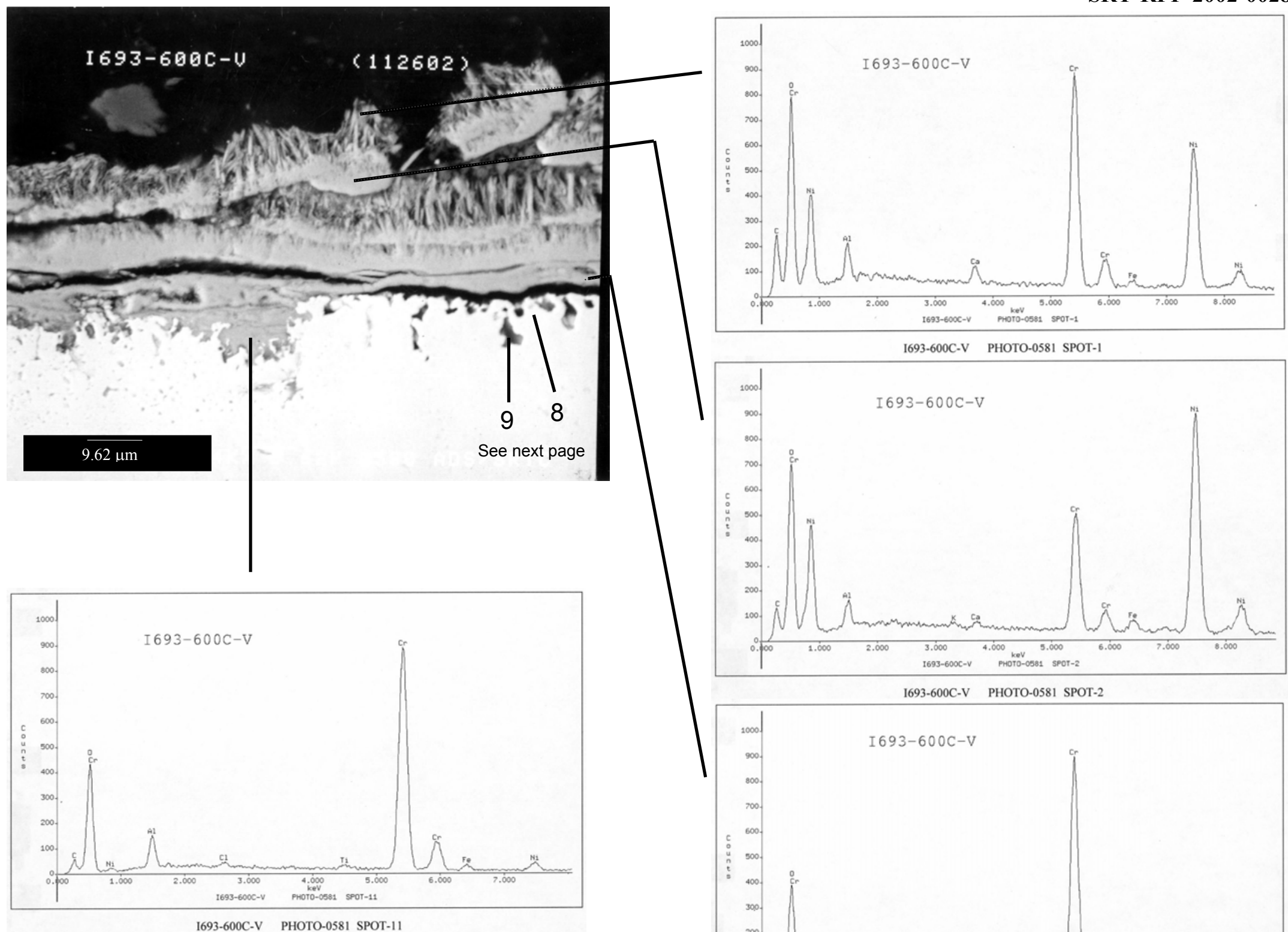

693-600C-V PHOTO-0581 SPOT-2

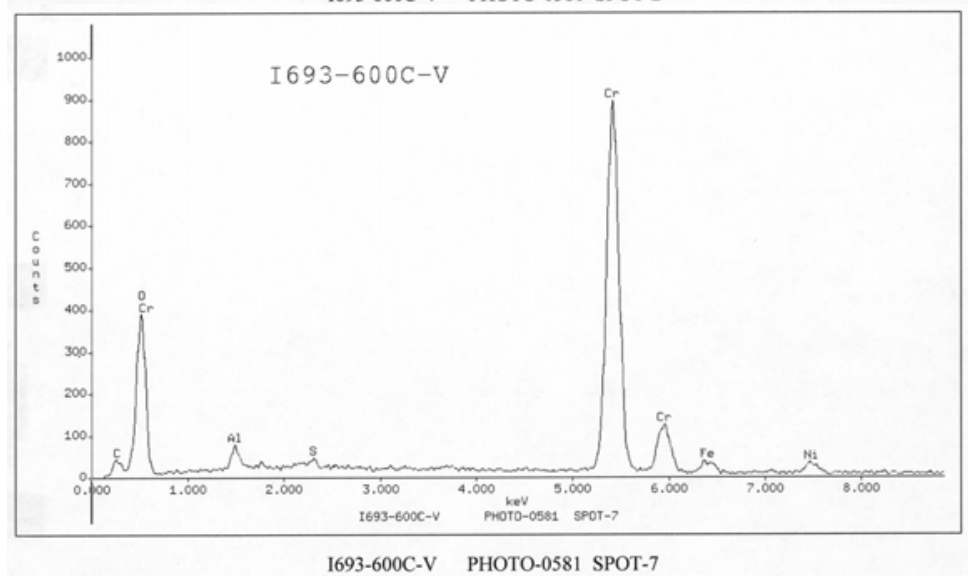

Page A-35 of 54 
WSRC-TR-2002-00588, REV. 0 SRT-RPP-2002-00283. REV. 0

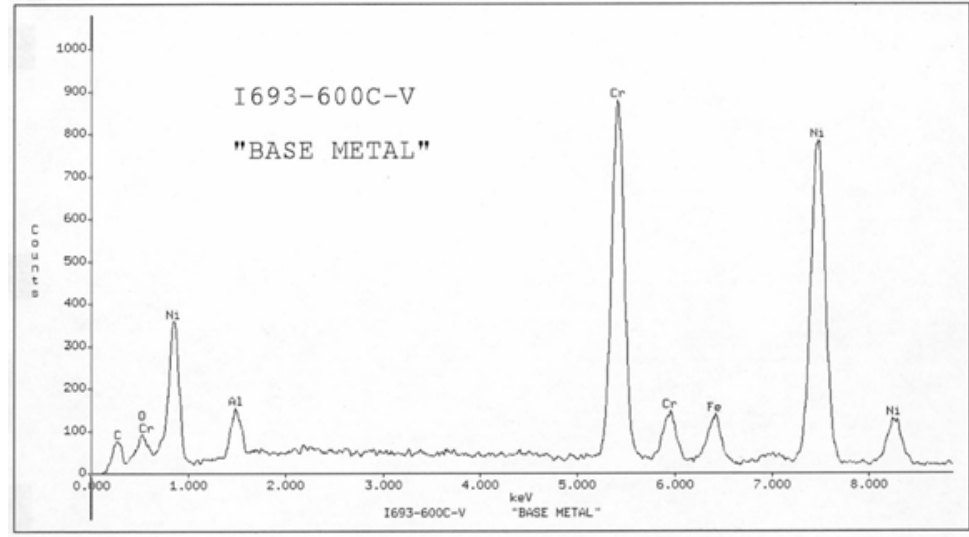

I693-600C-V "BASE METAL"

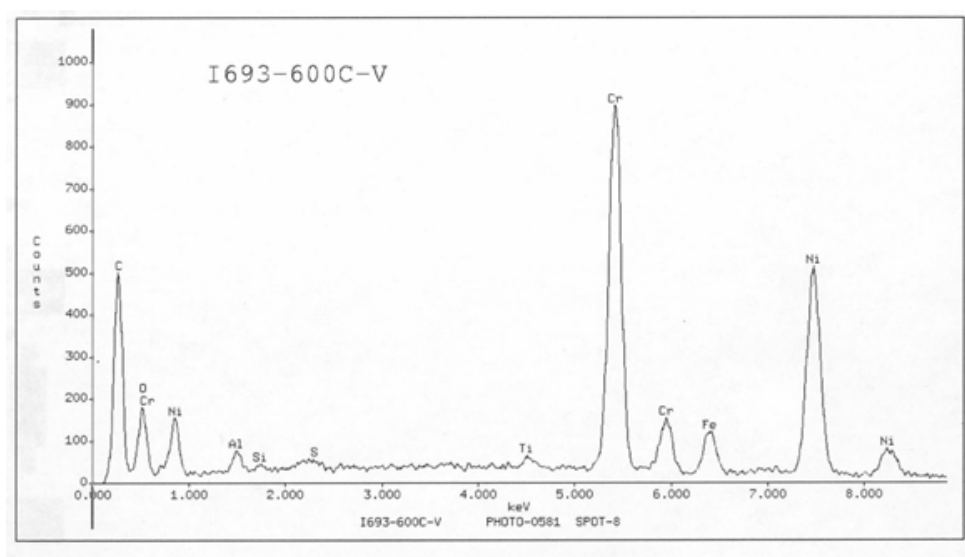

I693-600C-V PHOTO-0581 SPOT-8

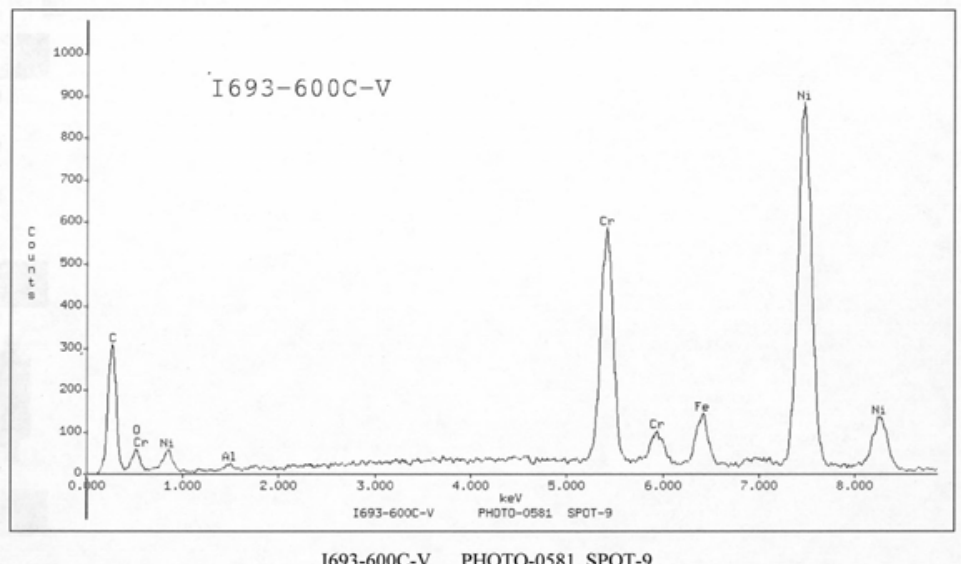

I693-600C-V PHOTO-0581 SPOT-9

Figure F-3 SEM and EDS of I-693 from $600^{\circ} \mathrm{C}$ Zone, cont.

Page 36 of 54 
WSRC-TR-2002-00588, REV. 0 SRT-RPP-2002-00283. REV. 0
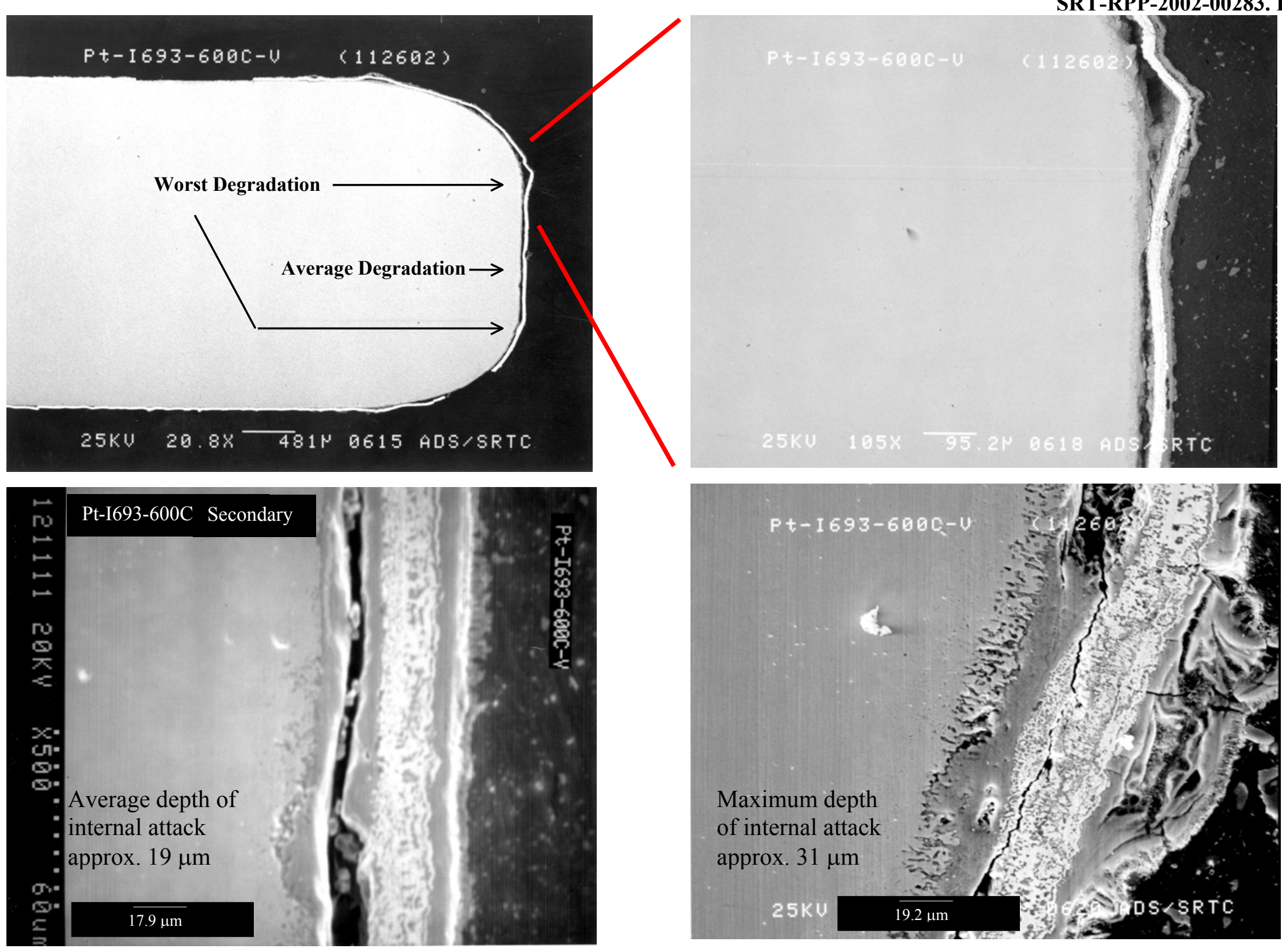

Figure F-4 SEMPhotos Showing Depth of Attack, Pt-Coated I-693 at $600^{\circ} \mathrm{C}$ 
WSRC-TR-2002-00588, REV. 0 SRT-RPP-2002-00283. REV. 0

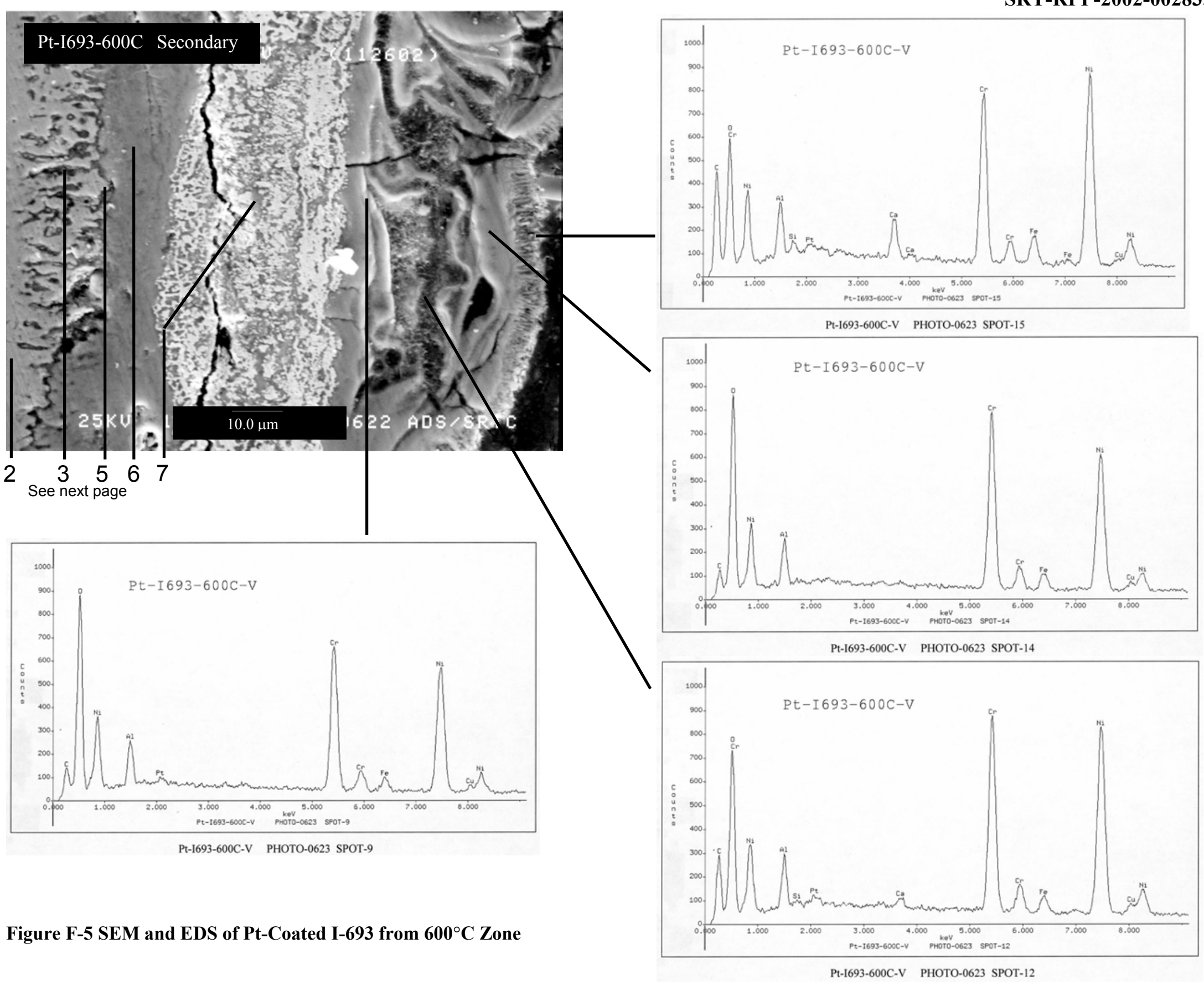

Page 38 of 54 
WSRC-TR-2002-00588, REV. 0 SRT-RPP-2002-00283. REV. 0

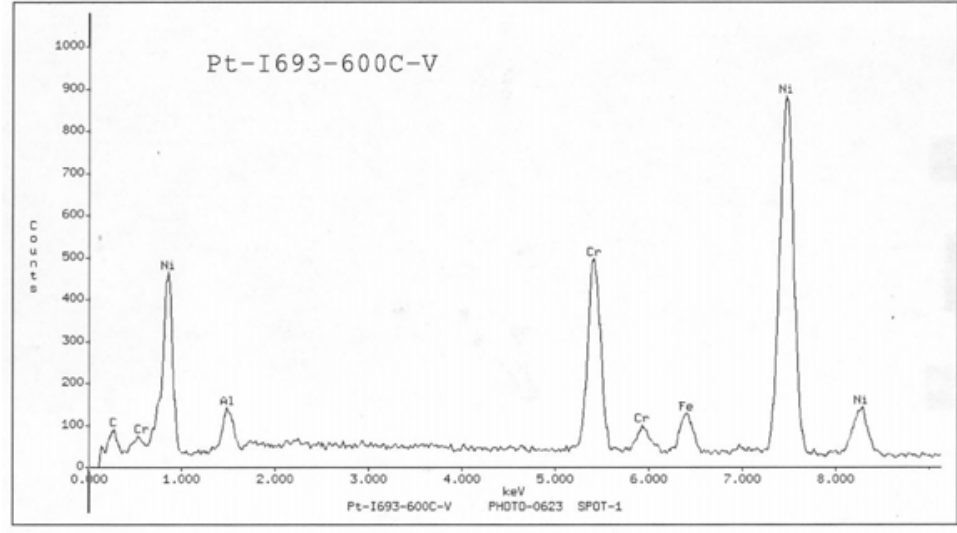

Pt-1693-600C-V PHOTO-0623 Base

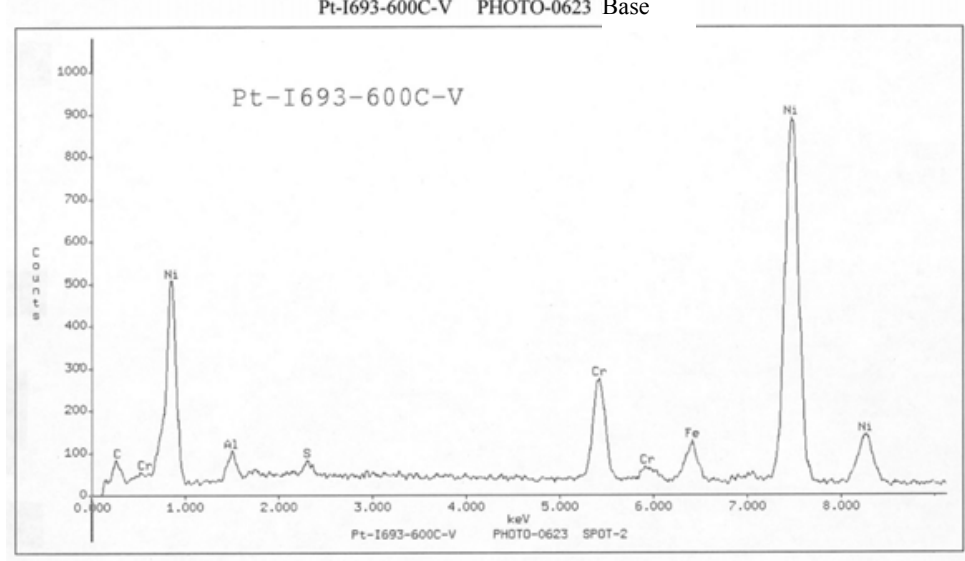

Pt-1693-600C-V PHOTO-0623 SPOT-2

Figure F-6 SEM and EDS of Pt-Coated I-693 from $600^{\circ} \mathrm{C}$ Zone, cont.

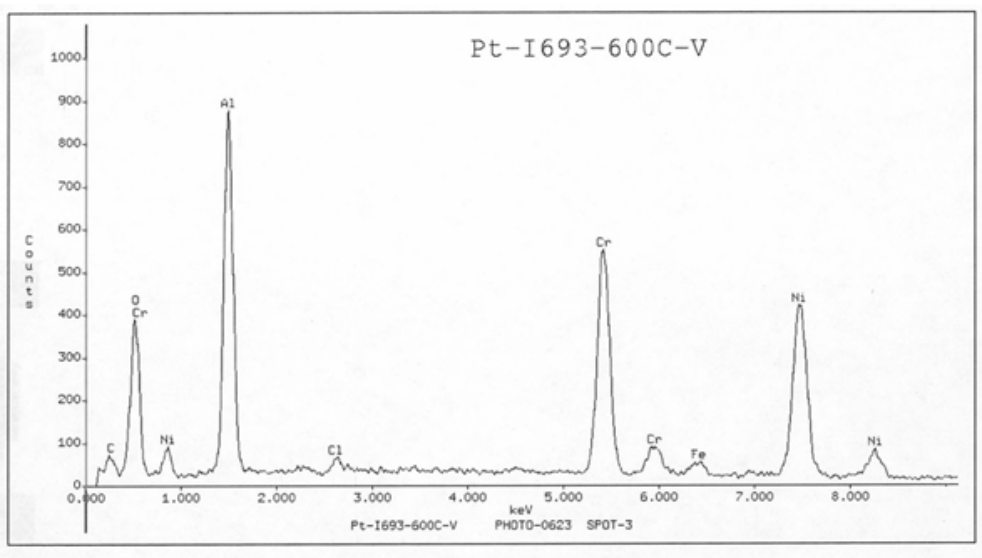

Pt-1693-600C-V PHOTO-0623 SPOT-3

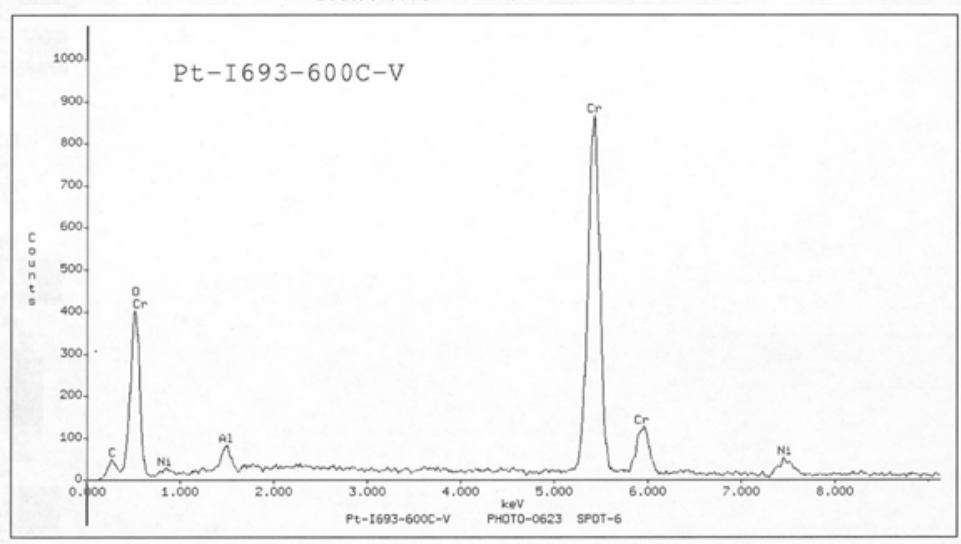

Pt-1693-600C-V PHOTO-0623 SPOT-6

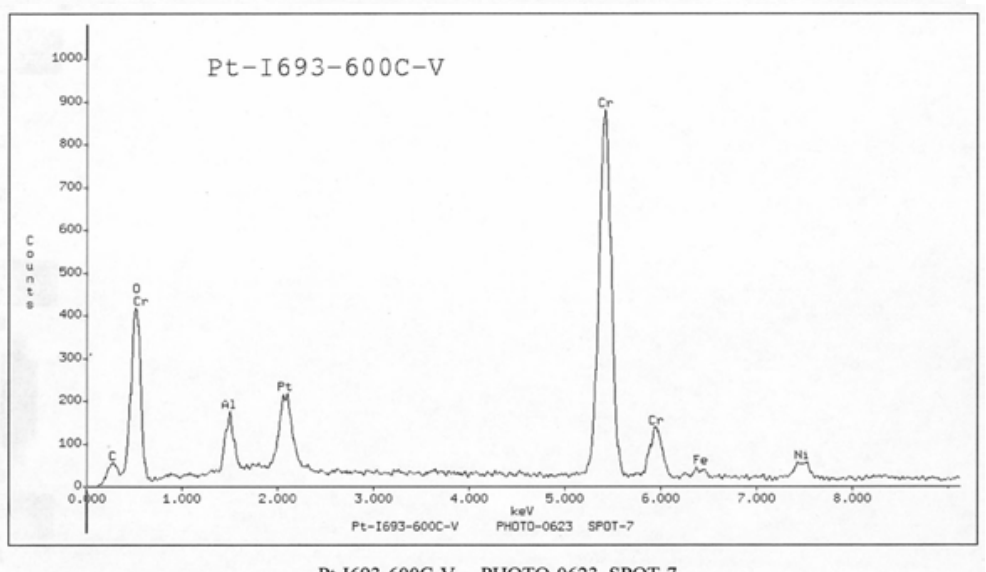

Pt-1693-600C-V PHOTO-0623 SPOT-7 
WSRC-TR-2002-00588, REV. 0 SRT-RPP-2002-00283. REV. 0
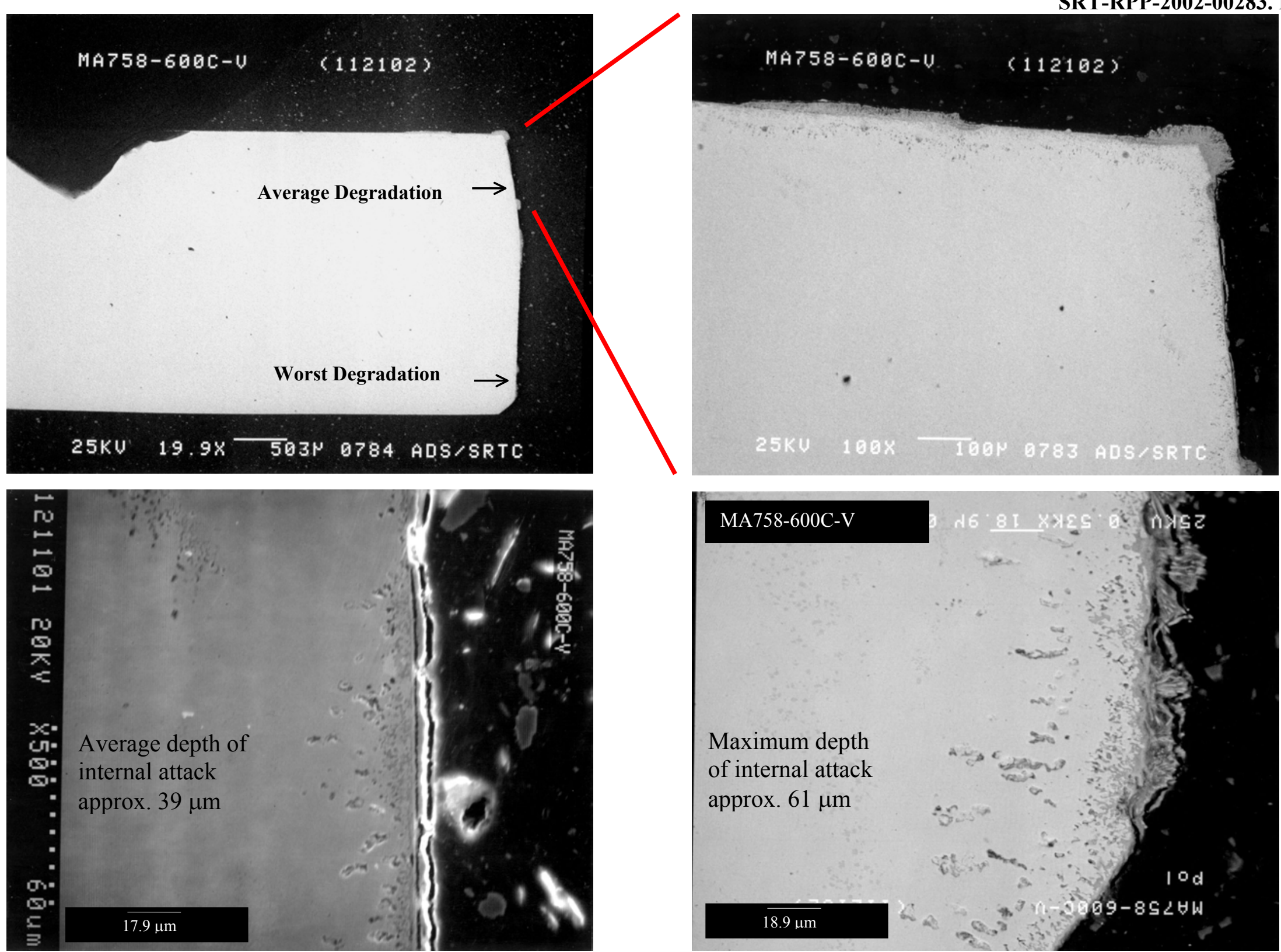

Figure F-7 SEMPhotos Showing Depth of Attack, MA758 at $600^{\circ} \mathrm{C}$

Page 40 of 54 
WSRC-TR-2002-00588, REV. 0
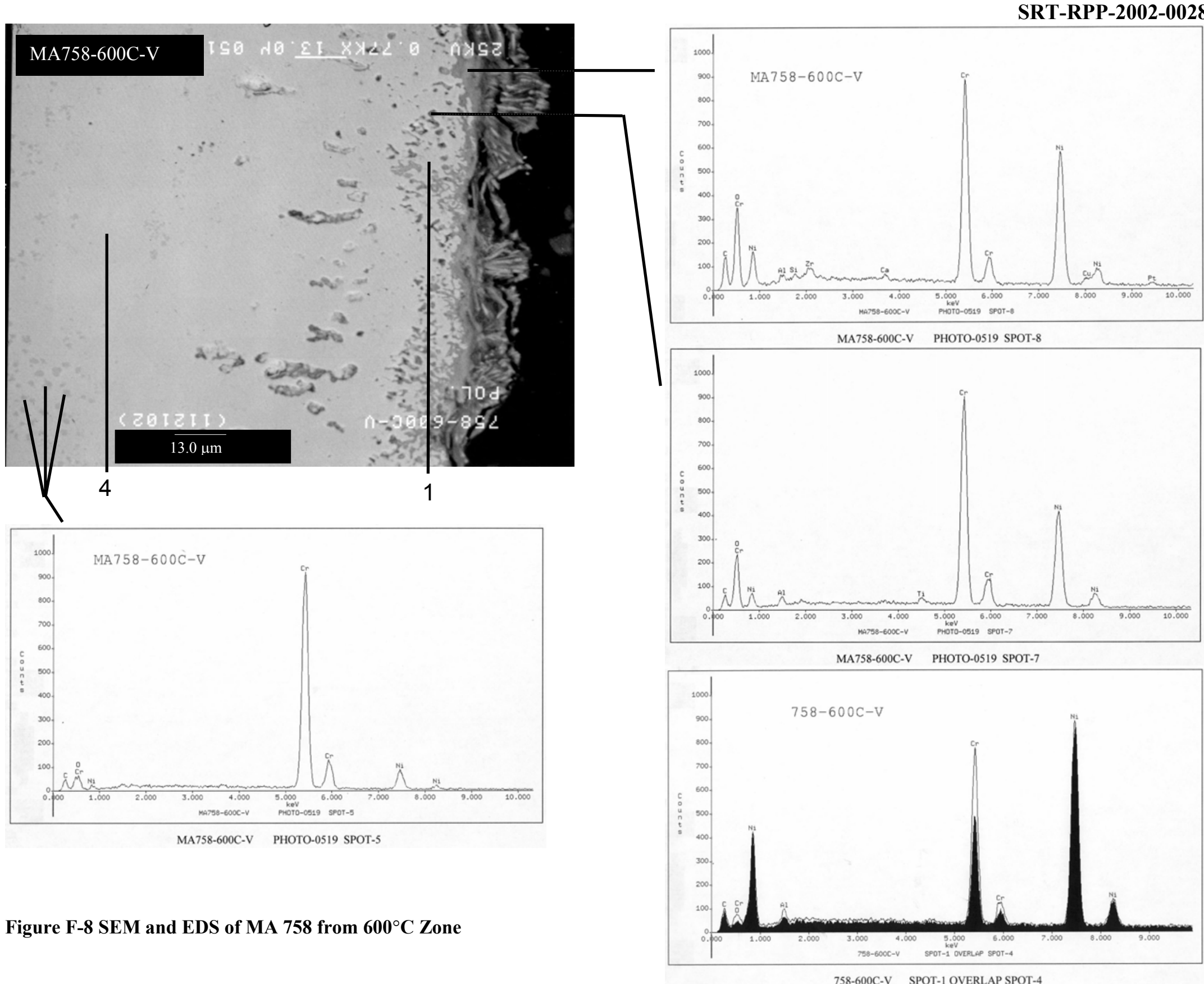

Page A-41 of 54 
WSRC-TR-2002-00588, REV. 0 SRT-RPP-2002-00283. REV. 0
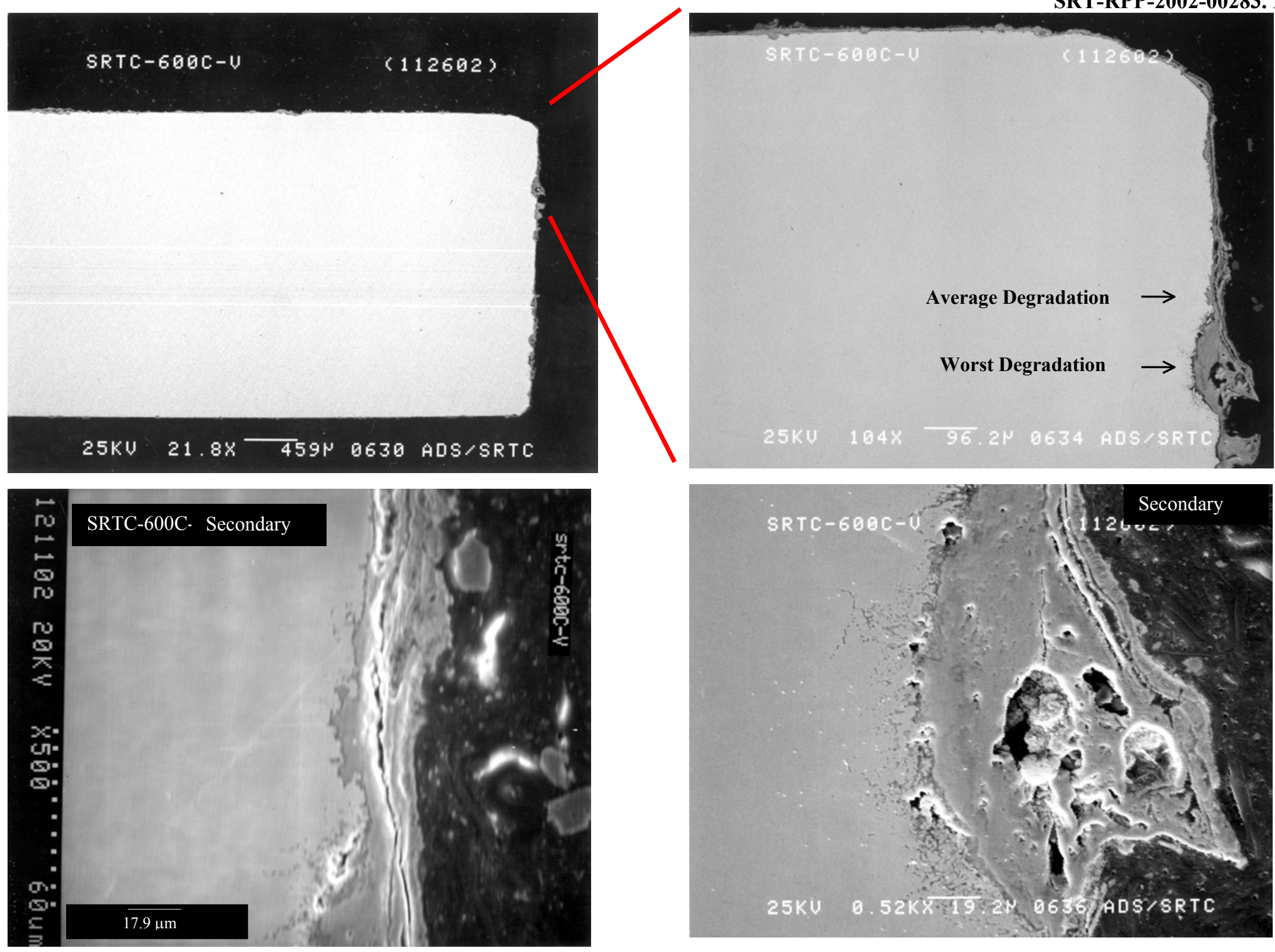

Figure F-9 SEMPhotos Showing Depth of Attack,SRTC Alloy at $600^{\circ} \mathrm{C}$

Page 42 of 54 
WSRC-TR-2002-00588, REV. 0 SRT-RPP-2002-00283. REV. 0
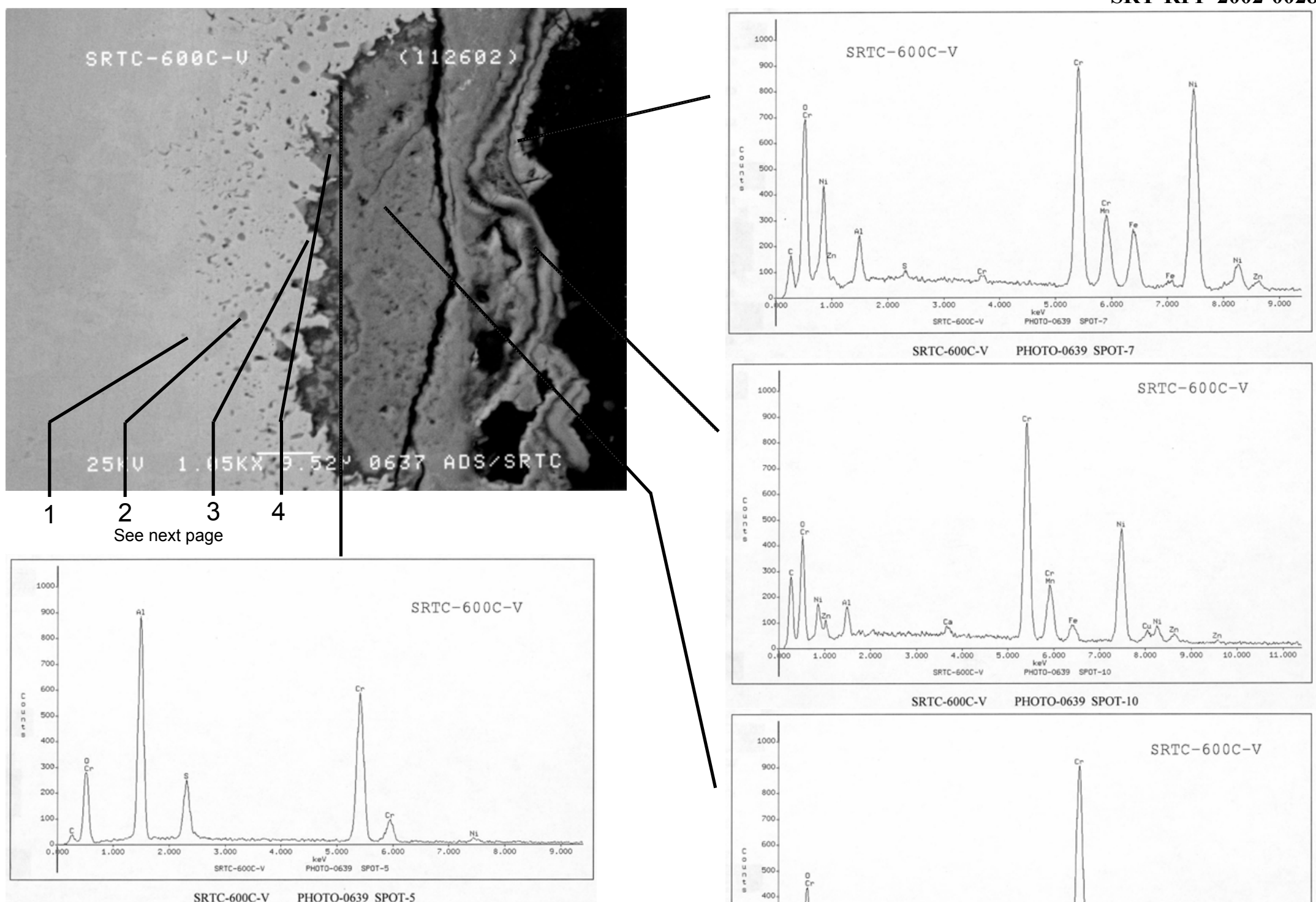

Figure F-10 SEM and EDS of SRTC Alloy from $600^{\circ} \mathrm{C}$ Zone

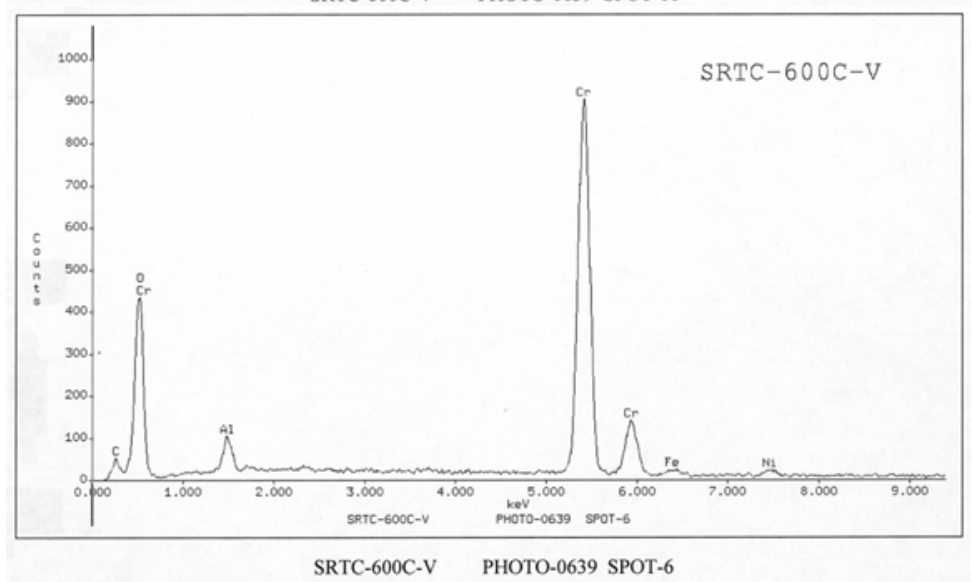

Page A-43 of 54 
WSRC-TR-2002-00588, REV. 0 SRT-RPP-2002-00283. REV. 0
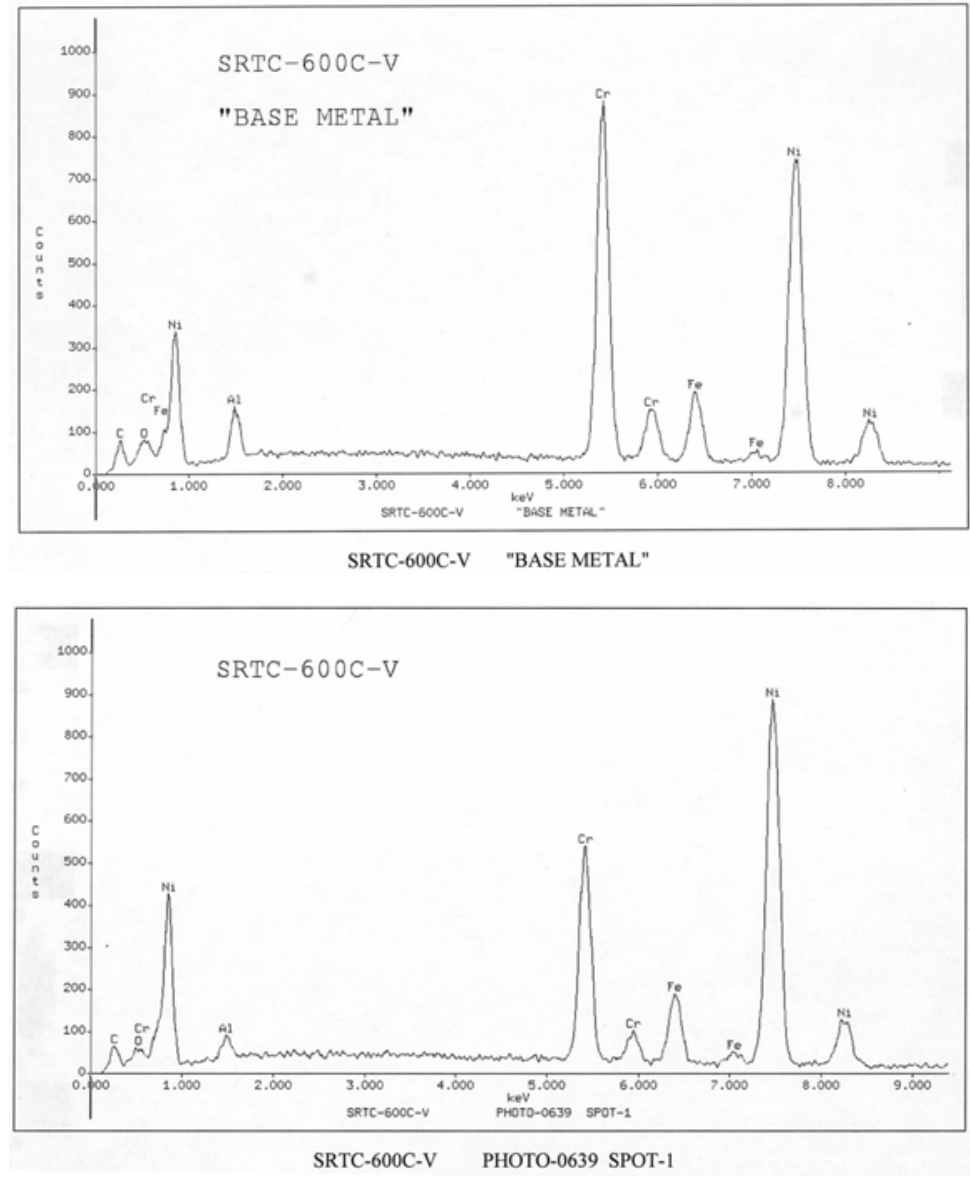

Figure F-11 SEM and EDS of SRTC Alloy from $600^{\circ} \mathrm{C}$ Zone, cont.

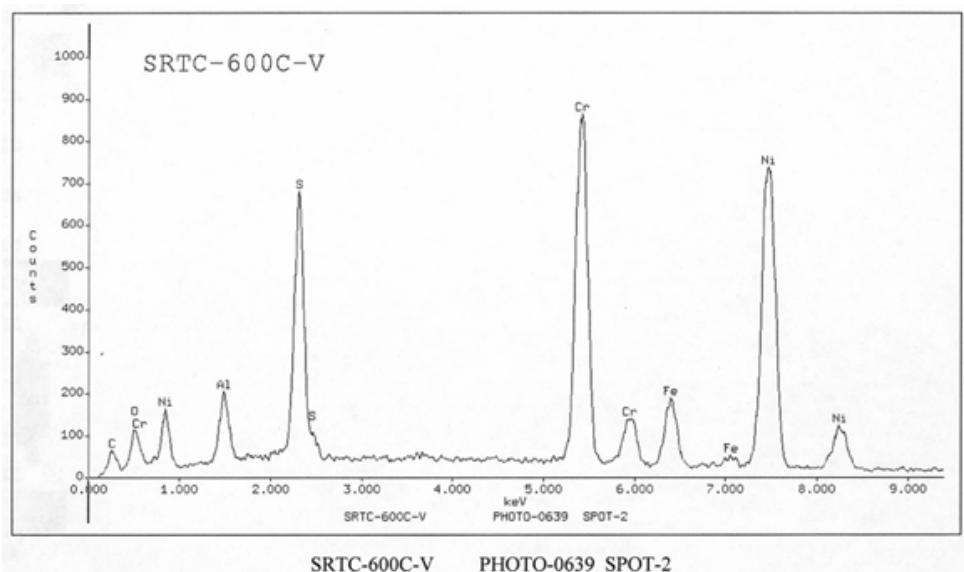

PHOTO-0639 SPOT-2

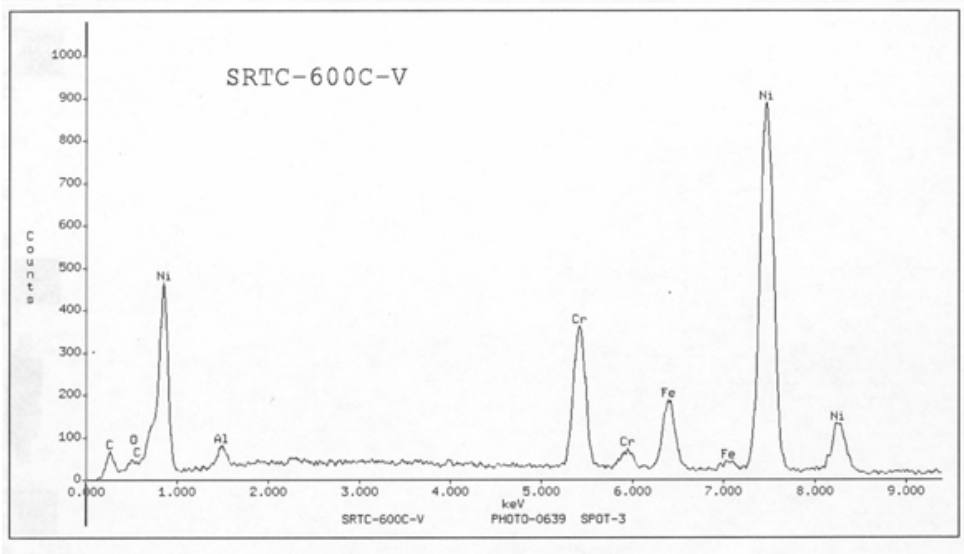

SRTC-600C-V PHOTO-0639 SPOT-3

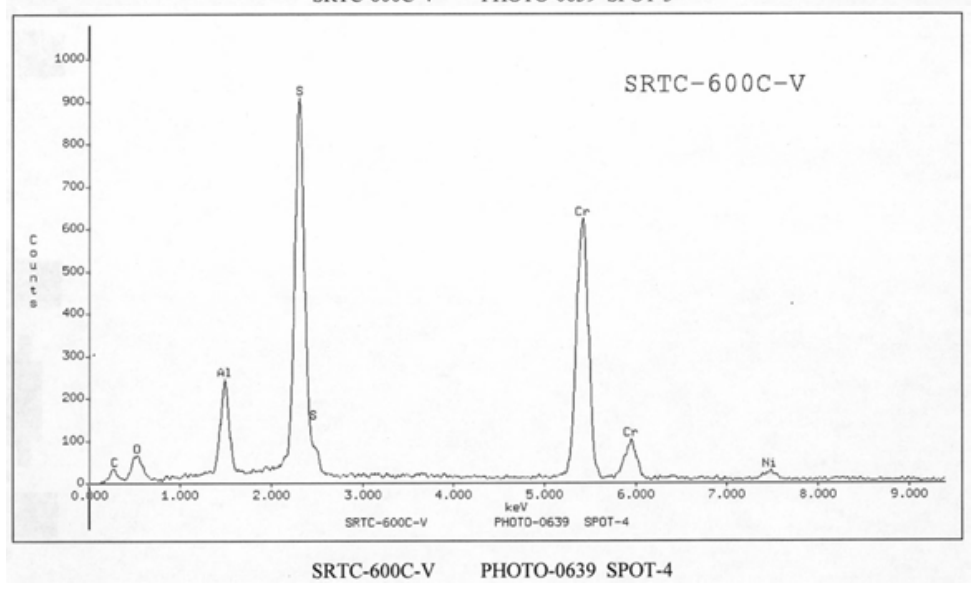

Page 44 of 54 
WSRC-TR-2002-00588, REV. 0

SRT-RPP-2002-00283. REV. 0

\section{APPENDIX G. $900^{\circ} \mathrm{C}$ SEM MICROGRAPHS FOR LONG-TERM VAPOR SPACE EXPERIMENT}


WSRC-TR-2002-00588, REV. 0 SRT-RPP-2002-00283. REV. 0
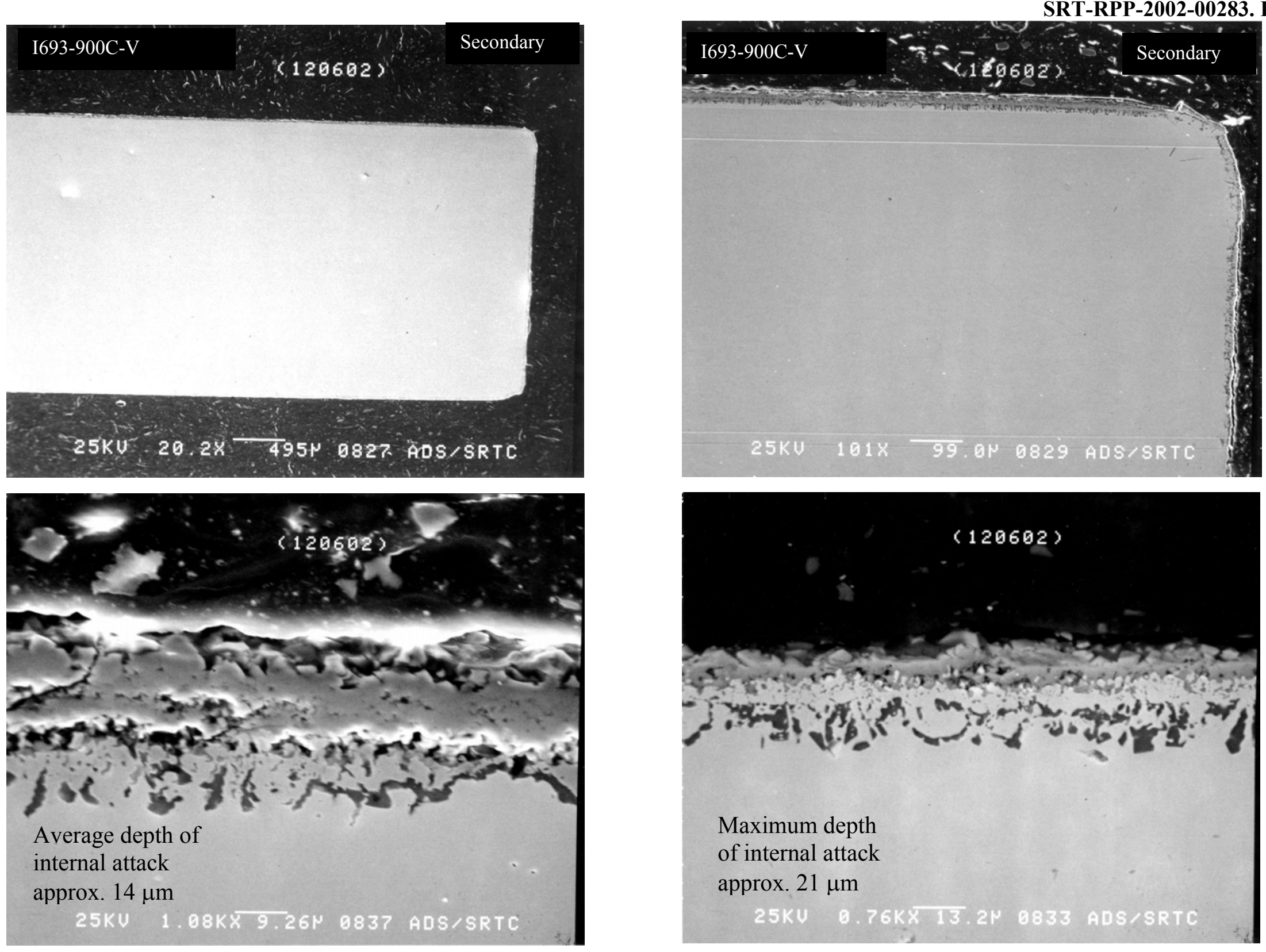

Figure G-1 SEMPhotos Showing Depth of Attack, I-693 at $900^{\circ} \mathrm{C}$ 
WSRC-TR-2002-00588, REV. 0 SRT-RPP-2002-00283. REV. 0
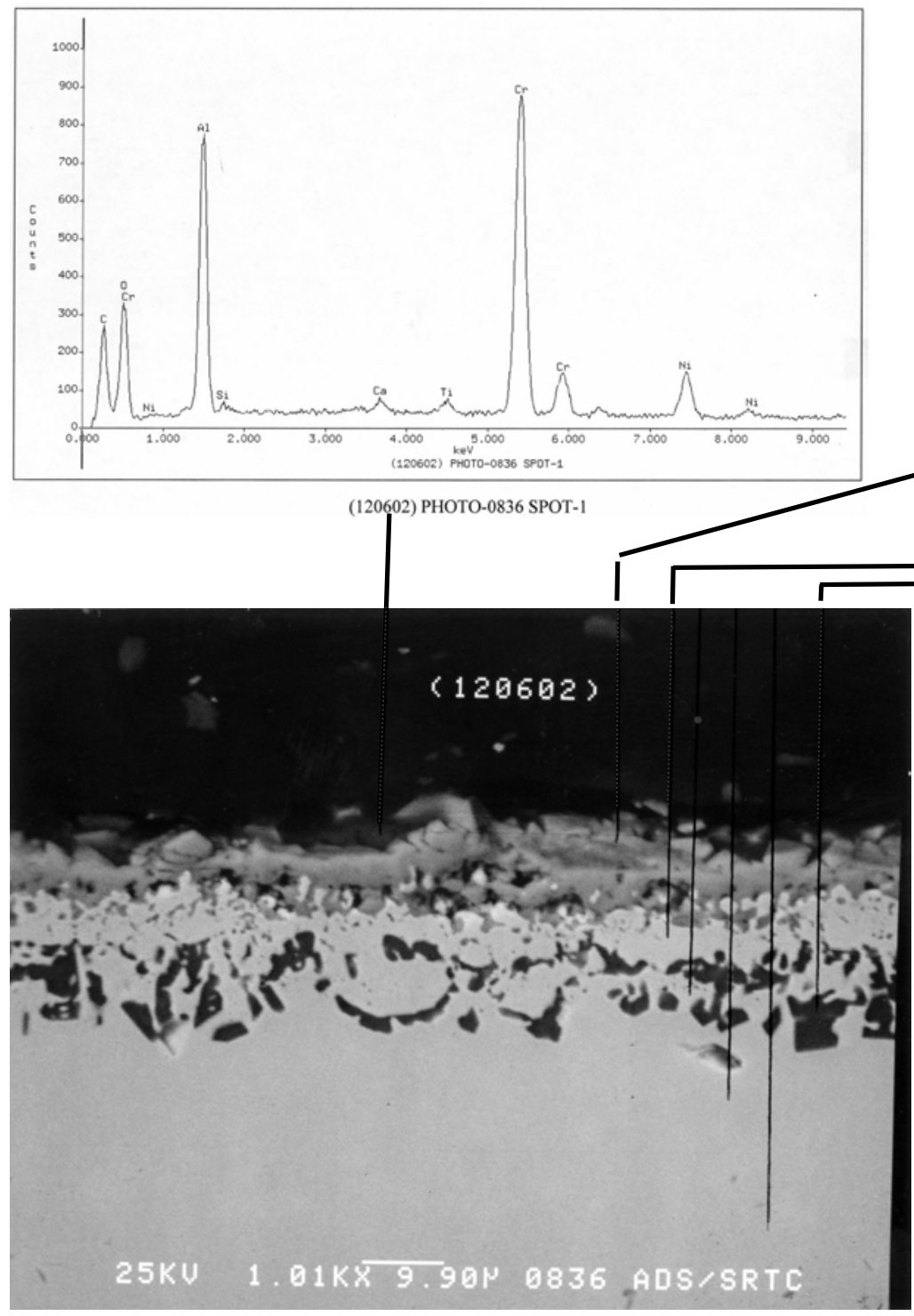

Figure G-2 SEM and EDS of I-693 from $900^{\circ} \mathrm{C}$ Zone

Page A-47 of 54

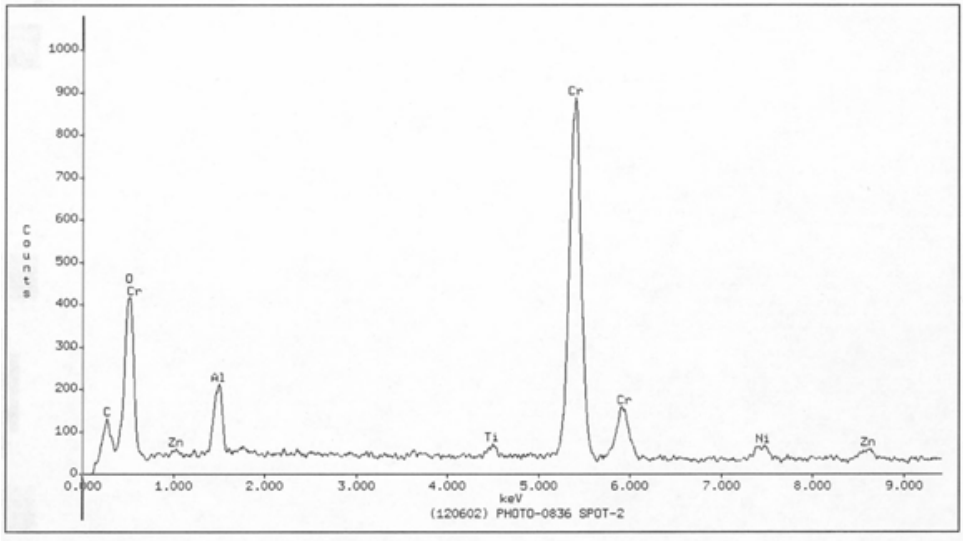

(120602) PHOTO-0836 SPOT-2

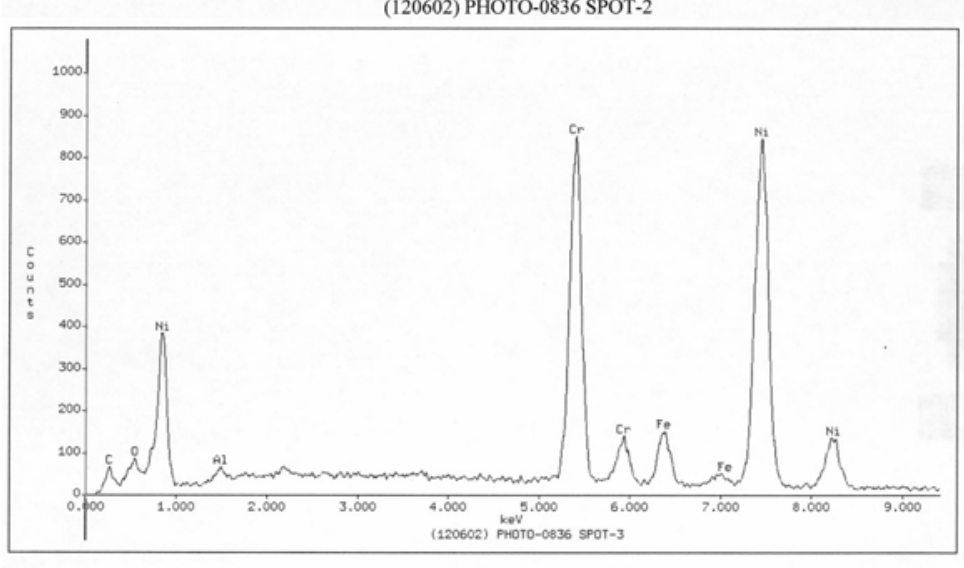

(120602) PHOTO-0836 SPOT-3

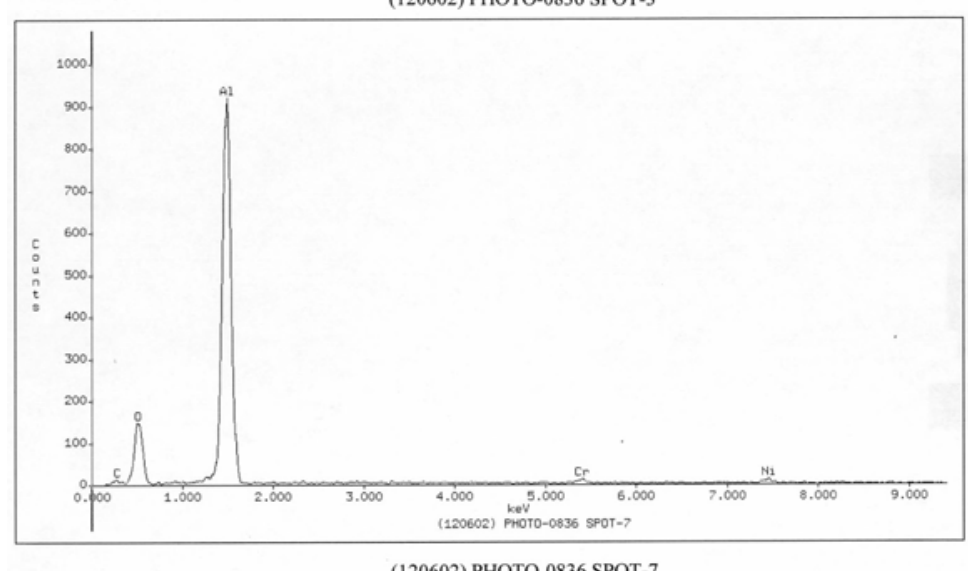

(120602) PHOTO-0836 SPOT-7 
WSRC-TR-2002-00588, REV. 0

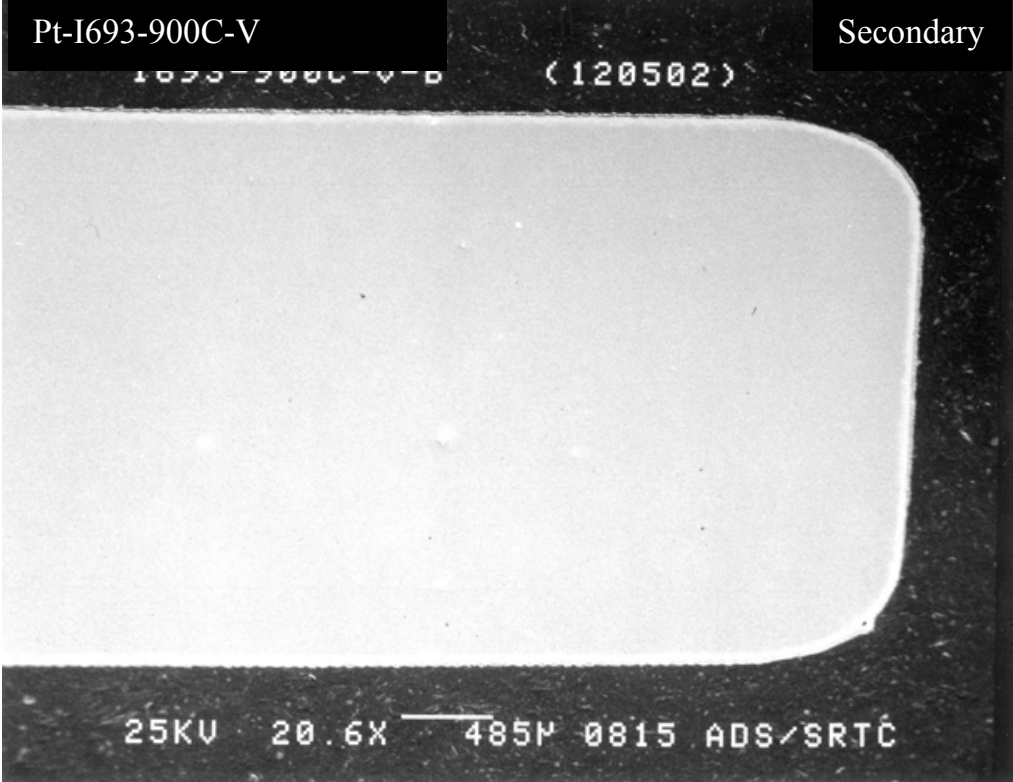

SRT-RPP-2002-00283. REV. 0

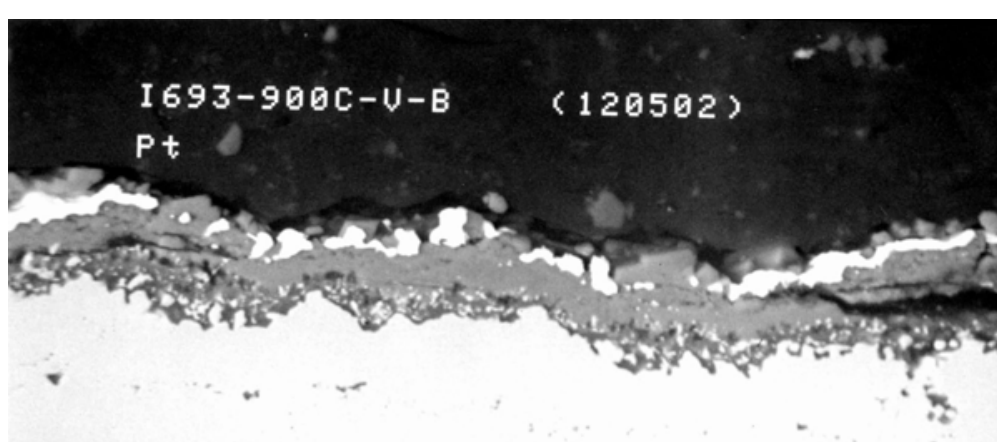

Average depth of internal attack approx. $14 \mu \mathrm{m}$

25KU 0.77KX 13. DN O823 ADS/SRTC

I $693-900 \mathrm{C}-\mathrm{U}-\mathrm{B}$ $\mathrm{Pt}$
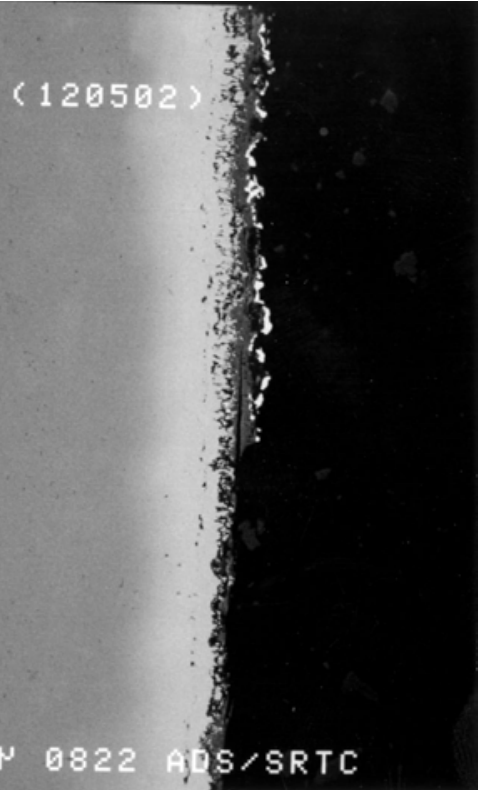

$25 K U 205 X \overline{48.8 N} 0822$ AISS/SRTC

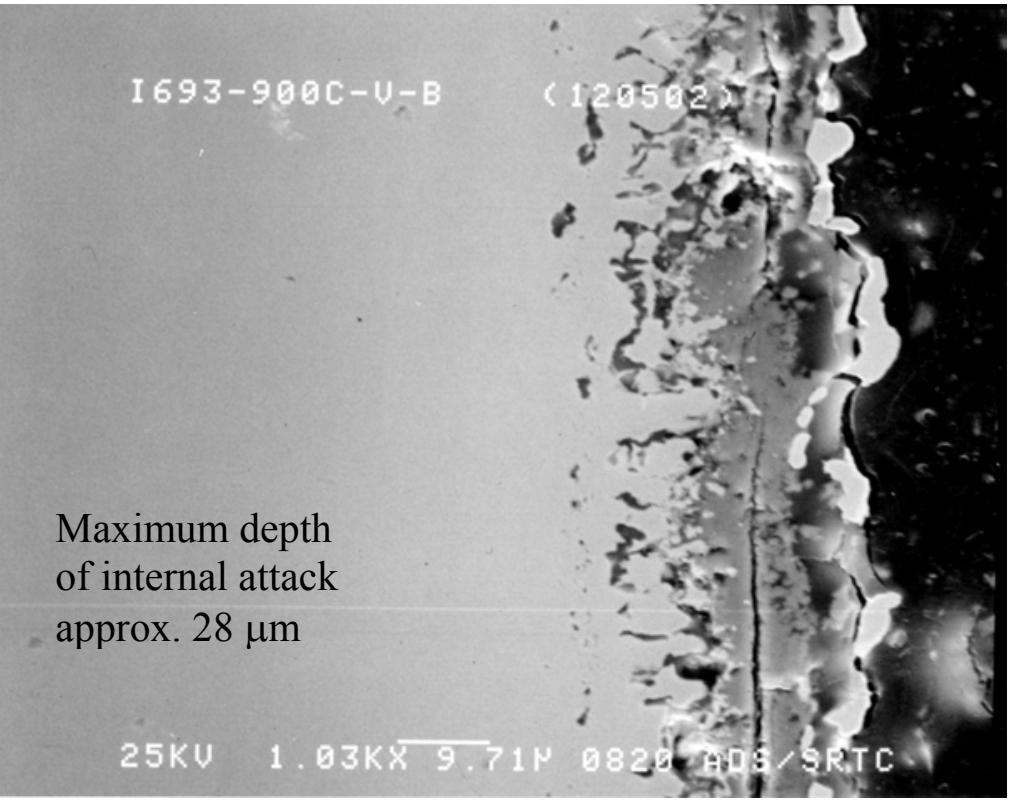

Figure G-3 SEMPhotos Showing Depth of Attack, Pt-Coated I-693 at $900^{\circ} \mathrm{C}$ 
WSRC-TR-2002-00588, REV. 0 SRT-RPP-2002-00283. REV. 0
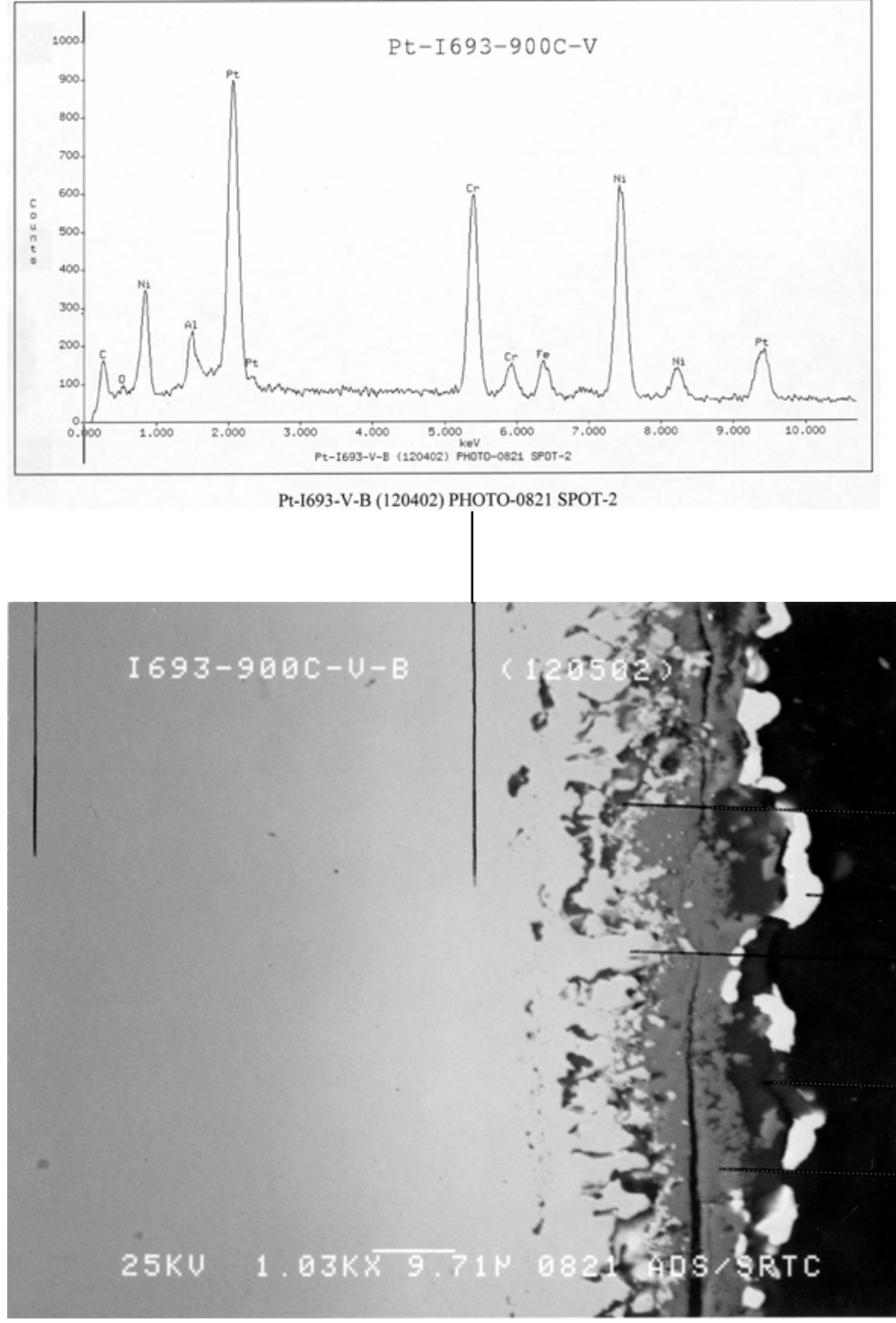

Figure G-4 SEM and EDS of Pt-Coated I-693 from $900^{\circ} \mathrm{C}$ Zone

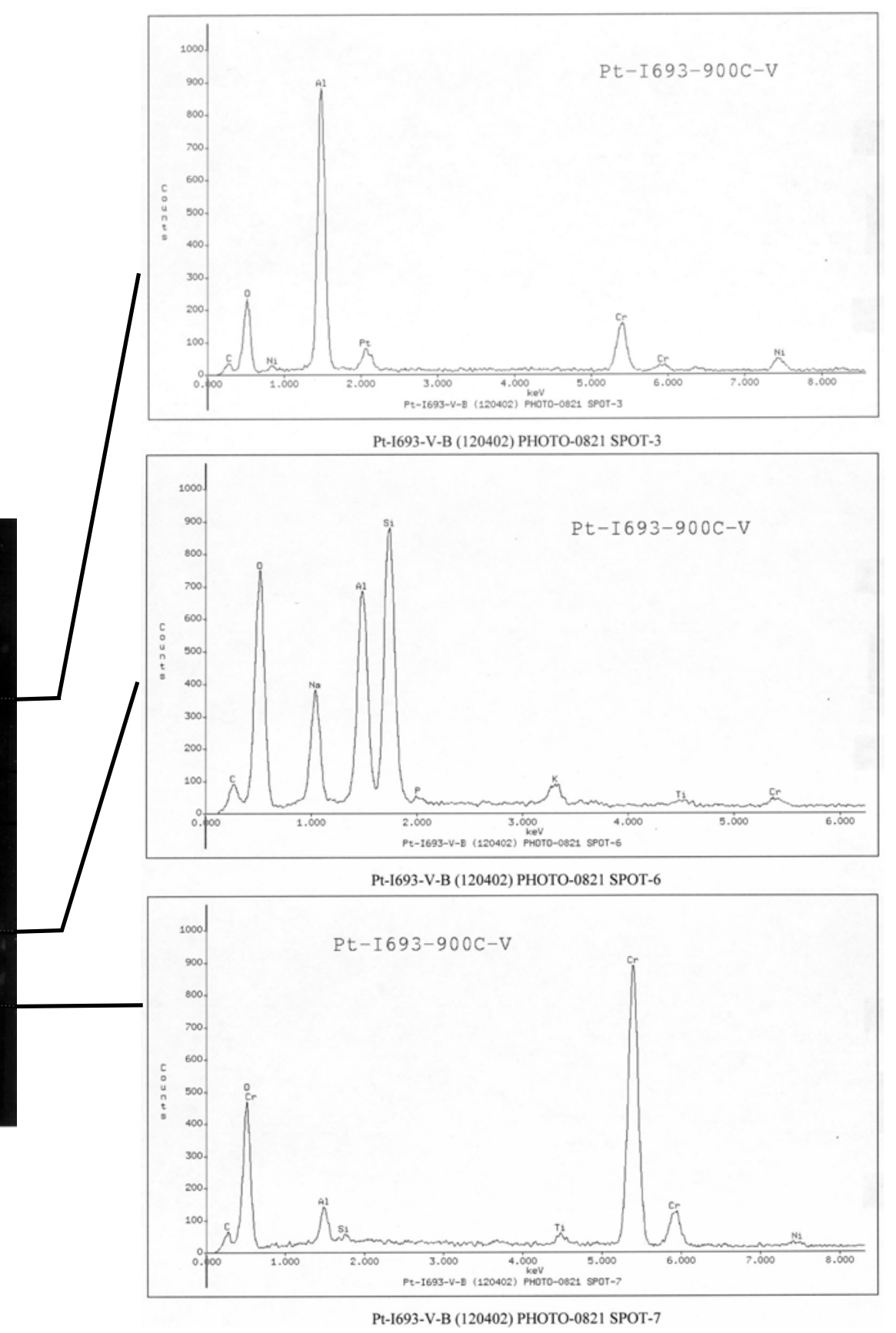

Page A-49 of 54 
WSRC-TR-2002-00588, REV. 0 SRT-RPP-2002-00283. REV. 0
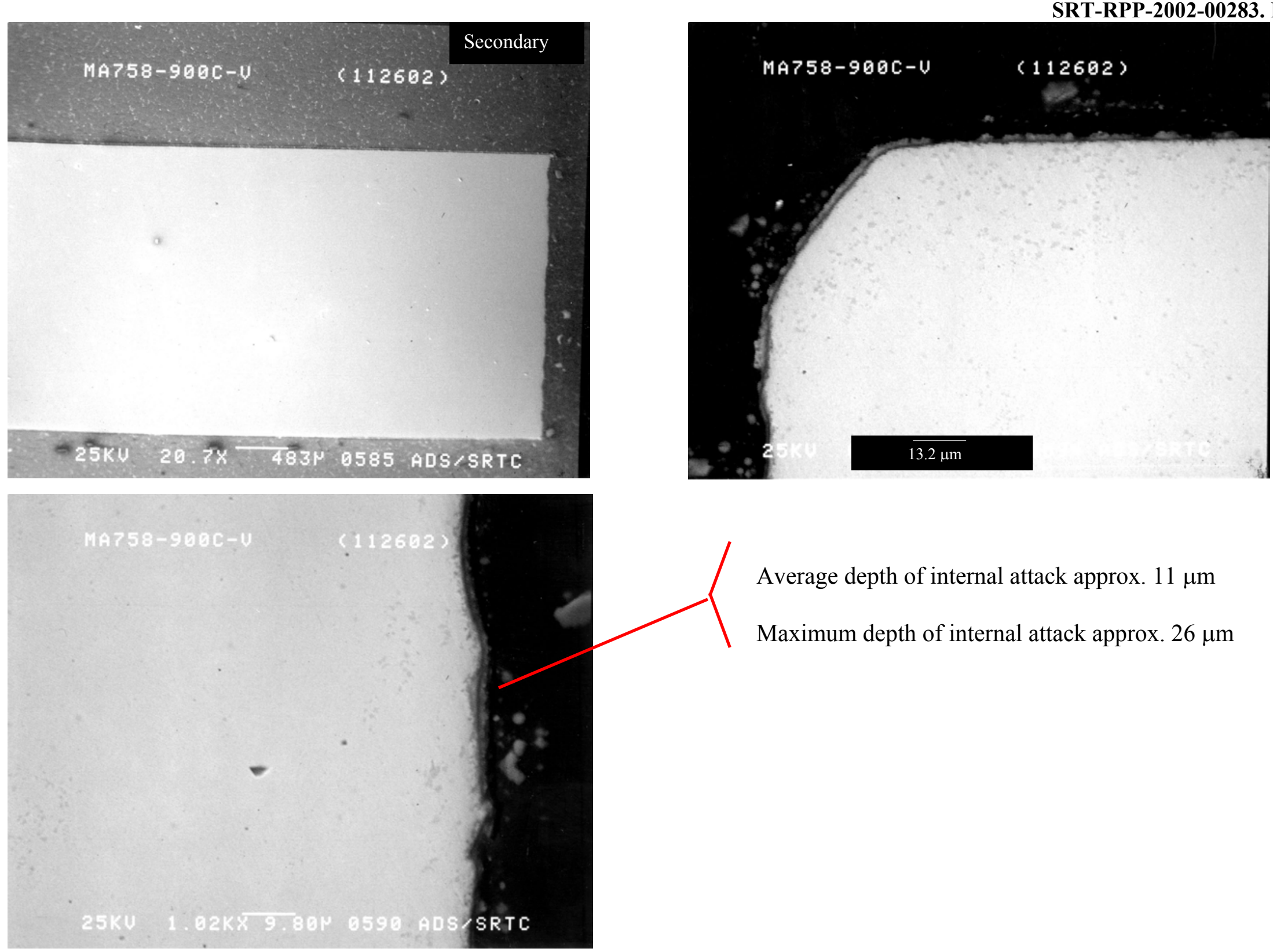

Average depth of internal attack approx. $11 \mu \mathrm{m}$

Maximum depth of internal attack approx. $26 \mu \mathrm{m}$

Figure G-5 SEMPhotos Showing Depth of Attack, MA758 at $900^{\circ} \mathrm{C}$ 
WSRC-TR-2002-00588, REV. 0 SRT-RPP-2002-00283. REV. 0
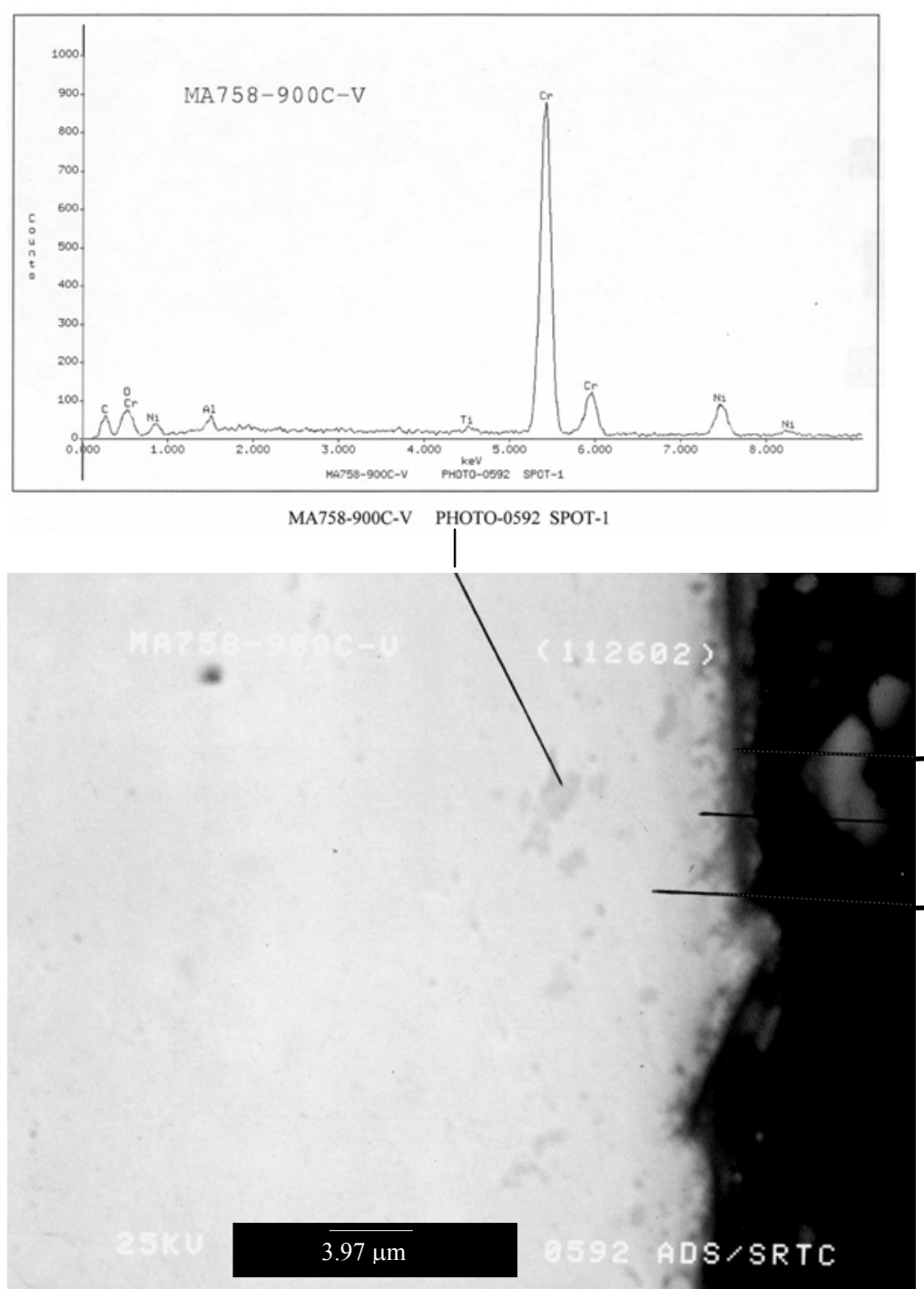

Figure G-6 SEM and EDS of MA 758 from $900^{\circ} \mathrm{C}$ Zone
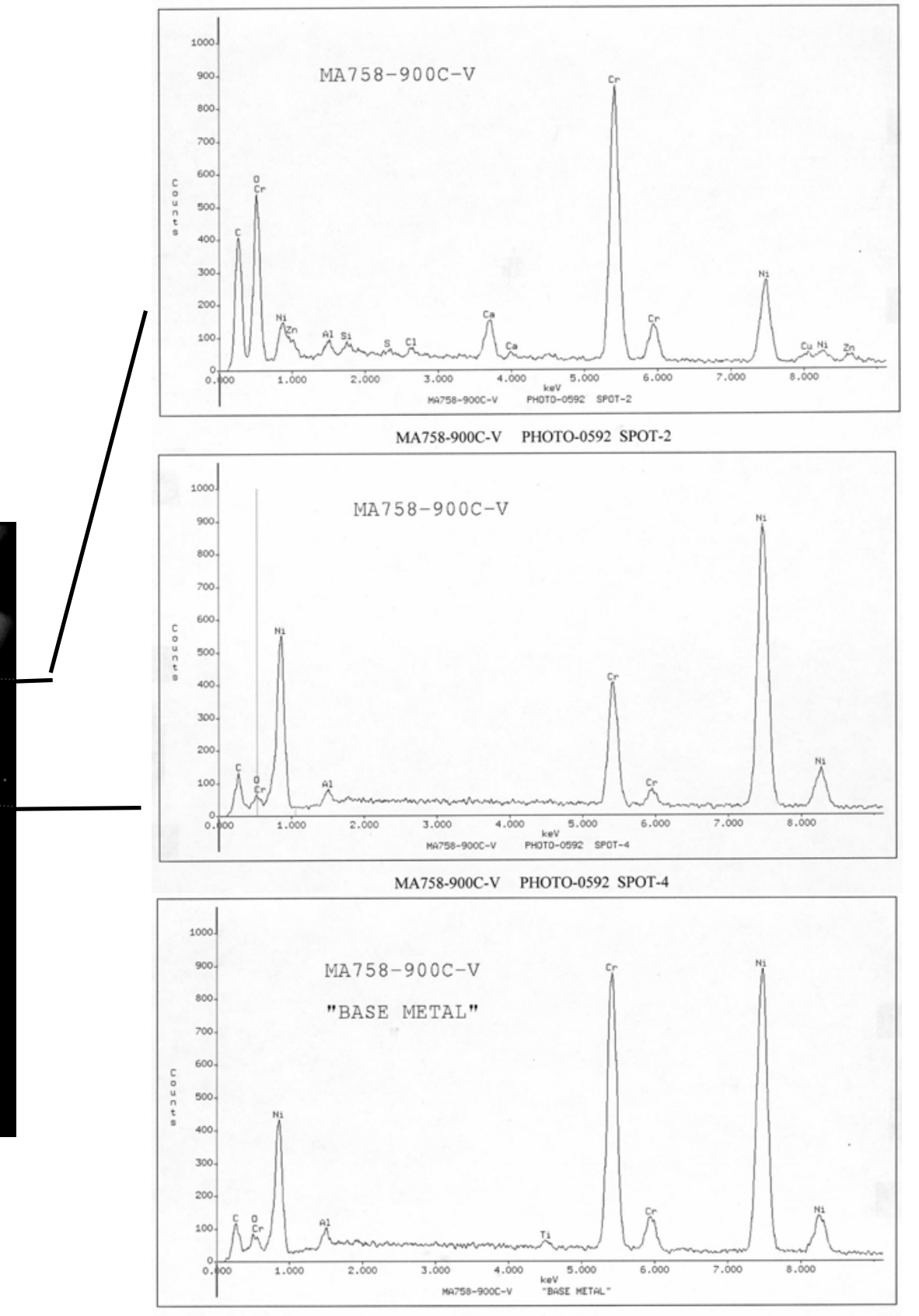

Page A-51 of 54 
WSRC-TR-2002-00588, REV. 0
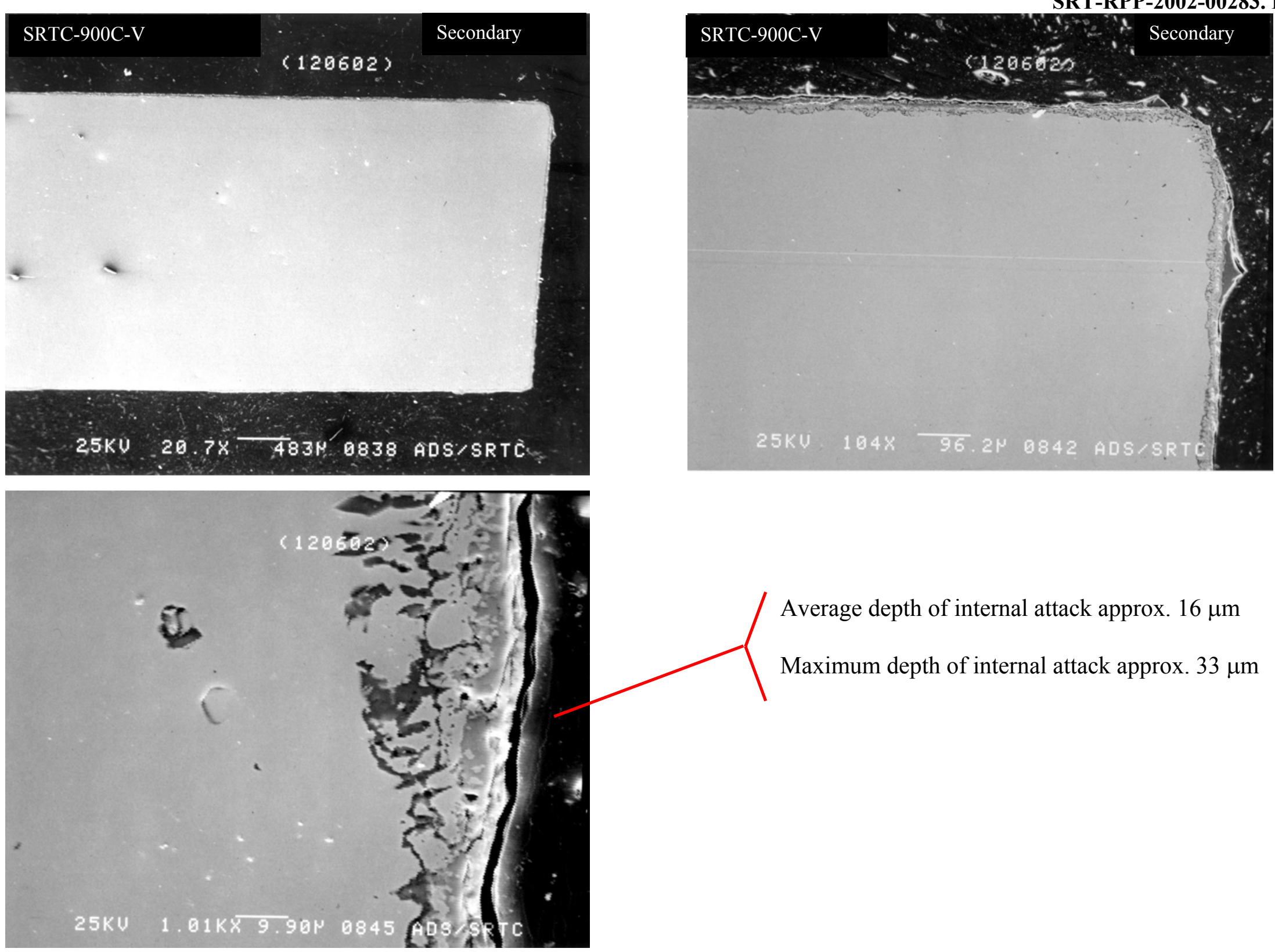

Figure G-7 SEMPhotos Showing Depth of Attack;SRTC Alloy at $900^{\circ} \mathrm{C}$ 
WSRC-TR-2002-00588, REV. 0 SRT-RPP-2002-00283. REV. 0

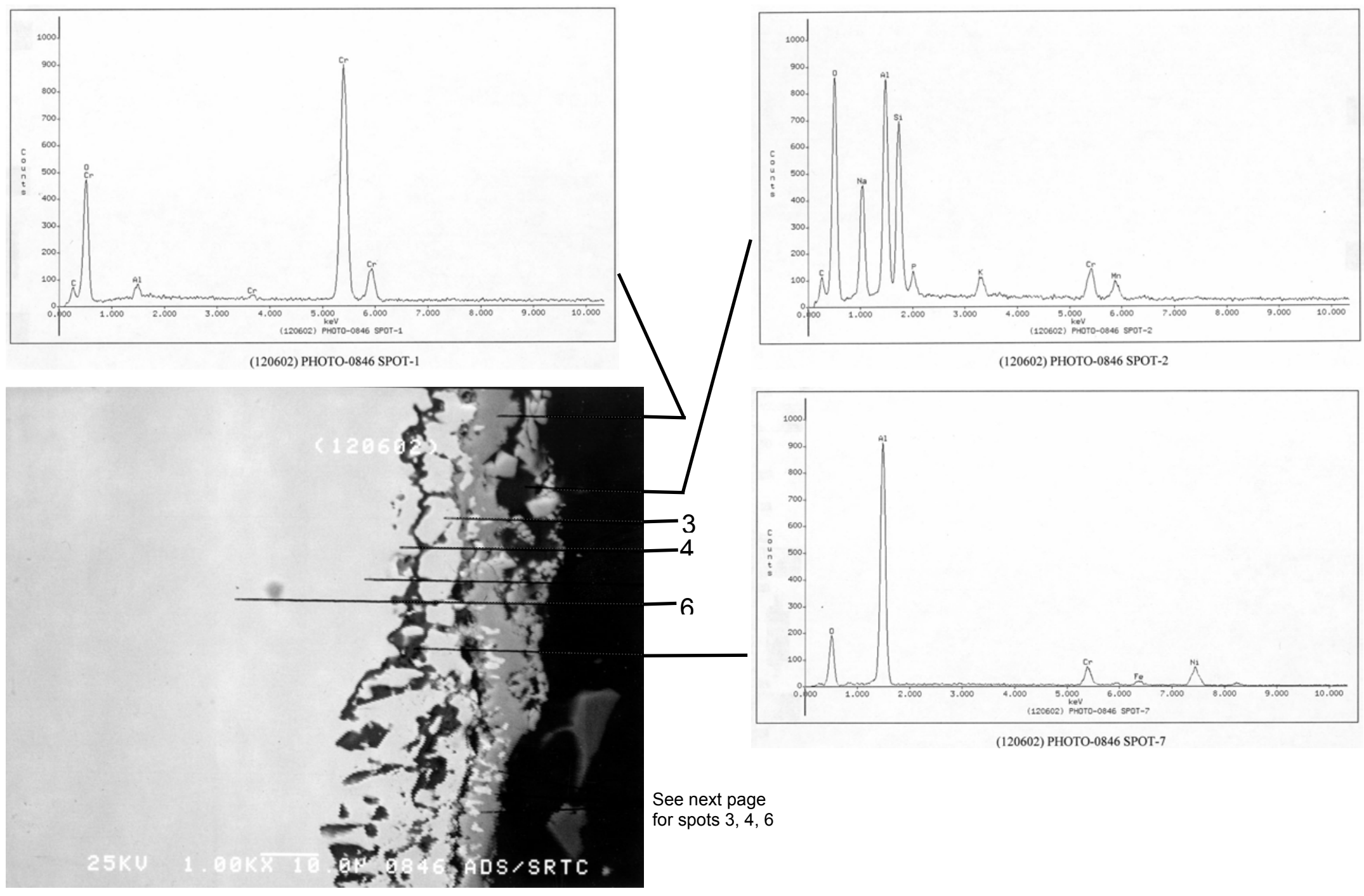

Figure G-8 SEM and EDS of SRTC Alloy from $900^{\circ} \mathrm{C}$ Zone 
WSRC-TR-2002-00588, REV. 0 SRT-RPP-2002-00283. REV. 0

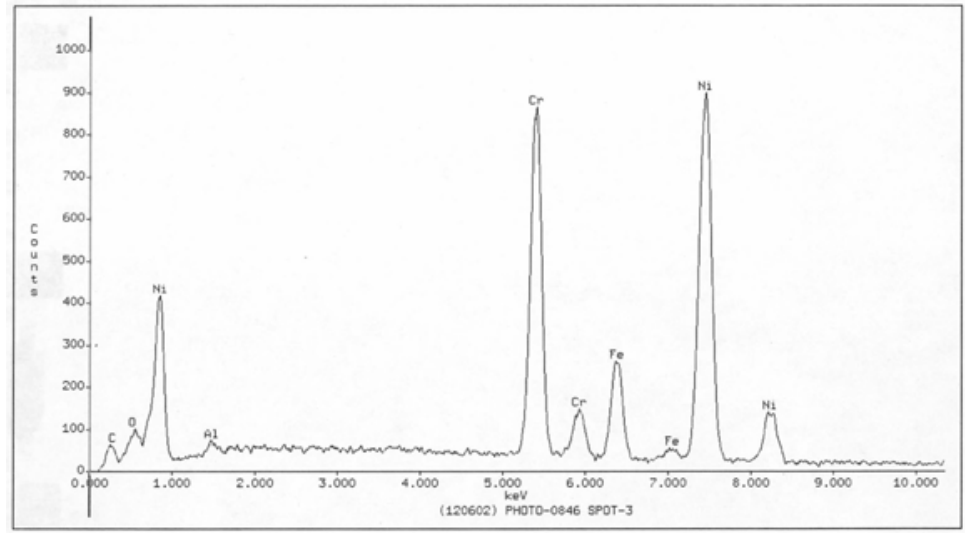

(120602) PHOTO-0846 SPOT-3

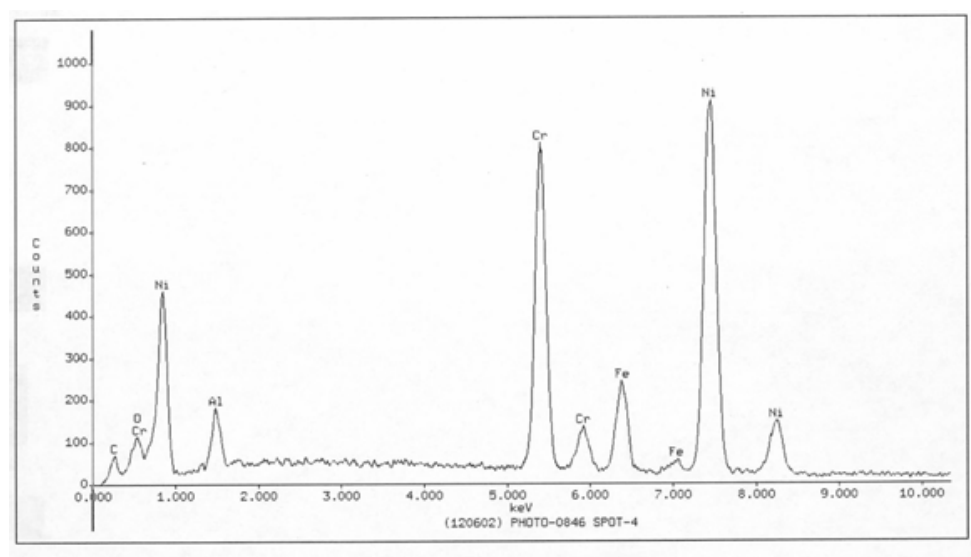

(120602) PHOTO-0846 SPOT-4

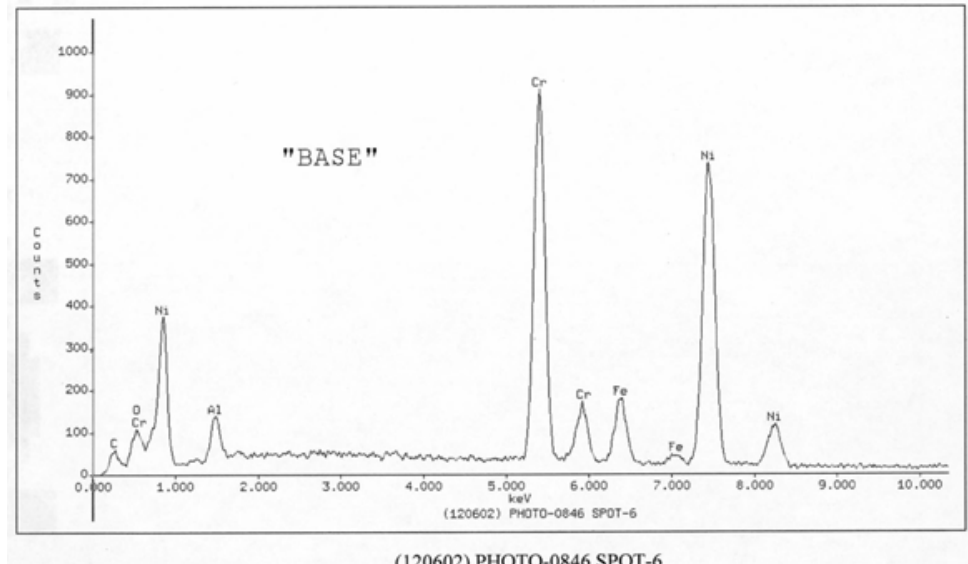

(120602) PHOTO-0846 SPOT-6 